\title{
PHYSICAL EXTENT, RECHARGE AREAS, RELATIVE POTENTIAL FOR RECHARGE AND CONTAMINATION, AND QUALITY OF WATER IN THE PRINCIPAL AQUIFERS, WESTERN KANE COUNTY, UTAH
}

By Lawrence E. Spangler, Geoffrey W. Freethey, and Gen A. Green

\section{U. S. GEOLOGICAL SURVEY}

Water-Resources Investigations Report 92-4070

Prepared in cooperation with the

UTAH DEPARTMENT OF ENVIRONMENTAL QUALITY, DIVISION OF WATER QUALITY,

KANE COUNTY, AND THE CITY OF KANAB

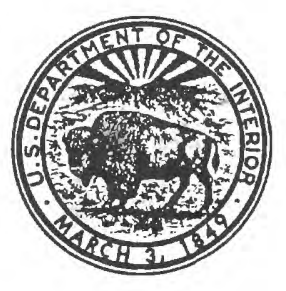

Salt Lake City, Utah 


\title{
U.S. DEPARTMENT OF THE INTERIOR
}

\section{BRUCE BABBITT, Secretary}

\author{
U.S. GEOLOGICAL SURVEY
}

Dallas L. Peck, Director

For additional information writc to:

District Chicf

U.S. Gcological Survcy, WRD

Room 1016 Administration Building

1745 West 1700 South

Salt Lakc City, Utah 84104
Copics of this report can be purchascd from:

U.S. Gcological Survcy

Books and Opcn-Filc Reports Scction

Federal Center

Box 25425

Denver, Colorado 80225 


\section{CONTENTS}

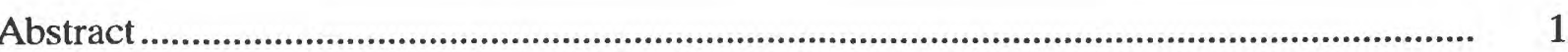

Introduction

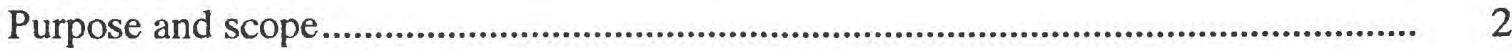

Previous investigations ......................................................................................... 2

Methods of investigation ...............................................................................................

Data-site numbering system....................................................................................... 5

Physical setting .................................................................................................................. 5

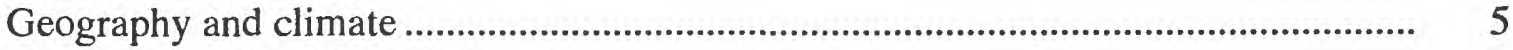

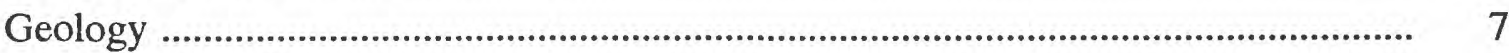

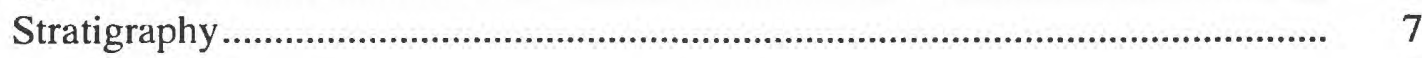

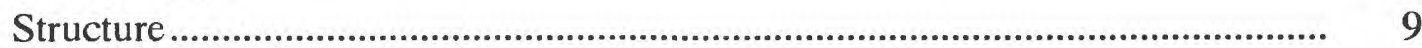

Physical extent and thickness of the principal aquifers ......................................................... 9

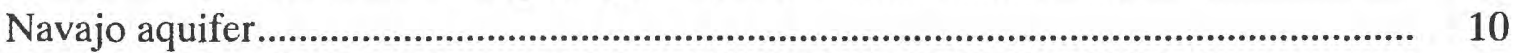

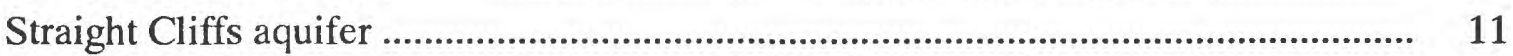

Alluvial aquifers .................................................................................................... 14

Recharge areas and relative potential for recharge to the principal aquifers ........................ 14

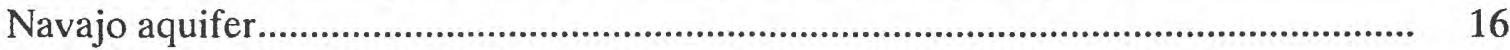

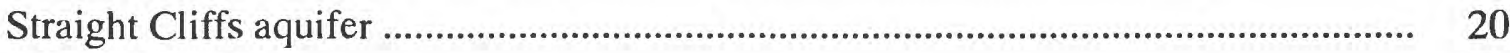

Alluvial aquifers ................................................................................................... 21

Potential for contamination of ground water in recharge areas ............................................. 22

Navajo aquifer ..................................................................................................... 22

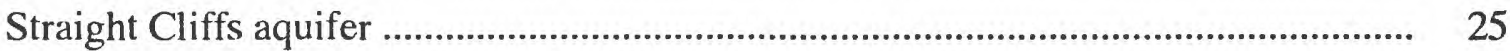

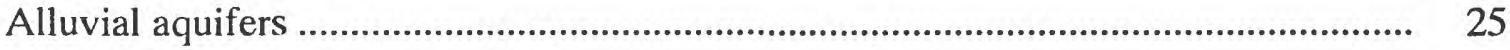

Quality of water in the principal aquifers ..................................................................... 26

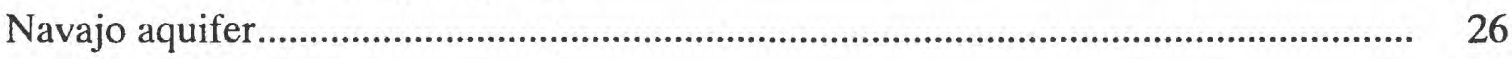

Straight Cliffs aquifer ........................................................................................ 41

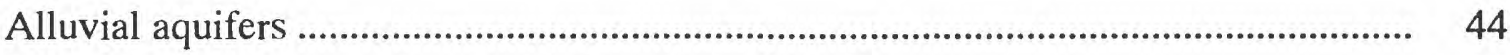

Classification of ground water in the principal aquifers................................................. 44

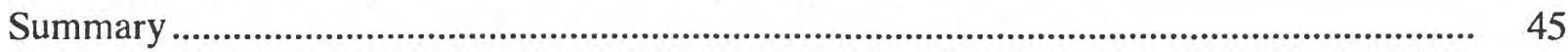

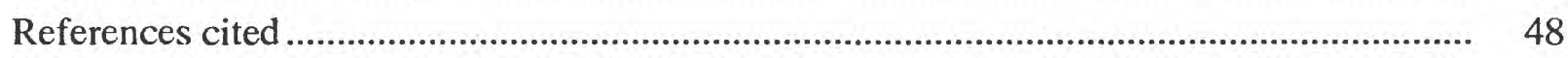

Supplemental information.............................................................................................. $\quad 50$ 


\section{ILLUSTRATIONS}

[Plate in pocket]

Page

Plate 1. Maps showing generalized geology of western Kane County and relative potential for recharge to the three principal aquifers.

Figure 1. Map showing location and geographic features of the study area................. 3

2. Diagram showing numbering system for geohydrologic-data sites in Utah.. 6

3. Schematic section showing relative thickness and stratigraphic relation of geologic and hydrologic units in the central part of the study area .........

4. Map showing outcrop of formations that include the principal aquifers, saturated thickness of the upper Navajo and Lamb Point aquifers at selected wells, and winter precipitation rates in western Kane County...

5. Diagram showing ground-water recharge, movement, and discharge in the principal aquifers in the Kanab block

6. Map showing potentiometric surface and general direction of ground-water flow in the upper Navajo aquifer.

7. Map showing location of wells and springs, and concentration of dissolved solids in ground water.

\section{TABLES}

Table 1. State of Utah ground-water-quality standards for protection of drinking water.

2. Selected properties and chemical constituents in water from wells and springs in the study area

3. Selected trace element concentrations in water from wells and springs in the study area

4. Dissolved-solids concentration in water from wells and springs, and general classification according to the State of Utah Ground-Water-Quality Protection Regulations 


\section{CONVERSION FACTORS, ABBREVIATED WATER-QUALITY UNITS, AND VERTICAL DATUM}

\section{Multiply}

foot

foot per day

foot per mile

inch

mile

square mile
By

0.3048

0.3048

0.1894

25.4

0.0254

1.609

2.59
To obtain

meter

meter per day

meter per kilometer

millimeter

meter

kilometer

square kilometer

Water temperature is given in degrees Celsius $\left({ }^{\circ} \mathrm{C}\right)$, which can be converted to degrees Fahrenheit $\left({ }^{\circ} \mathrm{F}\right)$ by the following equation:

$$
{ }^{\circ} \mathrm{F}=1.8\left({ }^{\circ} \mathrm{C}\right)+32
$$

Chemical concentration and water temperature are given only in metric units. Chemical concentration is given in milligrams per liter $(\mathrm{mg} / \mathrm{L})$ or micrograms per liter $(\mu \mathrm{g} / \mathrm{L})$. Milligrams per liter is a unit expressing the solute per unit volume (liter) of water. One thousand micrograms per liter is equivalent to 1 milligram per liter. For concentrations less than 7,000 milligrams per liter, the numerical value is about the same as for concentrations in parts per million. Specific conductance is given in microsiemens per centimeter $(\mu \mathrm{S} / \mathrm{cm})$ at 25 degrees Celsius. 


\section{Classification of Natural Water}

(After Heath, 1989, table 2)

\begin{tabular}{lc}
\hline Salinity & $\begin{array}{c}\text { Dissolved-solids } \\
\text { concentrations } \\
\text { (milligrams per liter) }\end{array}$ \\
\hline Fresh & 0 to 1,000 \\
Slightly saline & 1,000 to 3,000 \\
Moderately saline & 3,000 to 10,000 \\
Very saline & 10,000 to 35,000 \\
Briny & Greater than 35,000 \\
\hline \multicolumn{1}{c}{ Hardness } & Calcium and magnesium \\
(milligrams per liter \\
as CaCO 3 )
\end{tabular}

Sea level: In this report "sea level" refers to the National Geodetic Vertical Datum of 1929 - a geodetic datum derived from a general adjustment of the first-order level nets of the United States and Canada, formerly called Sea Level Datum of 1929. 


\title{
PHYSICAL EXTENT, RECHARGE AREAS, RELATIVE POTENTIAL FOR RECHARGE AND CONTAMINATION, AND QUALITY OF WATER IN THE PRINCIPAL AQUIFERS, WESTERN KANE COUNTY, UTAH
}

\author{
by L. E. Spangler, G. W. Freethey, and G. A. Green
}

\begin{abstract}
The Navajo aquifer, Straight Cliffs aquifer, and alluvial aquifers are the principal aquifers in western Kane County, Utah. The Navajo and Straight Cliffs aquifers are unconfined where the geologic formations that include the aquifers crop out, but are confined north of the outcrop areas where the formations are overlain by younger rocks. The alluvial aquifers are unconfined.

The Navajo aquifer is separated into the upper Navajo and Lamb Point aquifers where the Tenney Canyon Tongue of the Kayenta Formation is present. Thickness of the Navajo aquifer ranges from 50 to 100 feet where unconfined to as much as 2,000 feet where confined. Water movement in the Navajo aquifer is generally toward major incised drainages. The Straight Cliffs aquifer consists of the Straight Cliffs, Wahweap, and Kaiparowits Formations, which are presumed to be hydraulically connected. Thickness of the Straight Cliffs aquifer ranges from less than 100 feet near the erosional edge of the outcrops of the formations to about 2,000 feet to the north, where all formations are presumed to be saturated. Principal alluvial aquifers are present in the valleys of Thompson and Skutumpah Creeks, Alton Amphitheater, and Sink Valley. Thickness of aquifers in alluvium is generally less than 100 feet.

Recharge to the principal aquifers is by infiltration of precipitation into bedrock and through unconsolidated deposits covering bedrock, by losses from streams, by infiltration through overlying rocks, and by seepage along faults and joints. Factors influencing the quantity of recharge to the aquifers include quantity of winter precipitation; type and density of vegetative cover; evapotranspiration; thickness of soil cover; type, extent, and hydraulic conductivity of unconsolidated deposits; topographic slope; and the continuity, aperture, and spacing of vertical fractures.

Dissolved-solids concentrations in water from the Navajo aquifer ranged from 102 to 3,100 milligrams per liter, with a median of 230 milligrams per liter. Dissolved-solids concentrations in water from the Straight Cliffs aquifer ranged from 139 to 1,250 milligrams per liter, with a median of 330 milligrams per liter. Dissolved-solids concentrations in water from alluvial aquifers ranged from 283 to 3,500 milligrams per liter, with a median of 838 milligrams per liter. Water-quality data from 44 wells and 51 springs indicated that water in the principal aquifers can be classified according to the State of Utah Ground-Water-Quality Protection Regulations as Pristine, Irreplaceable, Ecologically Important, or Drinking-Water Quality.
\end{abstract}

\section{INTRODUCTION}

State and local water users have expressed concerns regarding the possible effects of commercial, agricultural, industrial, and residential development on the quantity and quality of water 
in the principal aquifers of western Kane County, southwestern Utah (fig. 1). These concerns are particularly directed toward the effects of withdrawals from aquifers in the Navajo Sandstone, which is the primary source of water for public and domestic supply in this part of the State. To address these concerns, the U.S. Geological Survey, in cooperation with the Utah Department of Environmental Quality, Division of Water Quality; Kane County; and the City of Kanab, determined the physical extent, recharge areas, relative potential for recharge and contamination, and quality of water in the principal aquifers. The Kanab Area Water Association through the Five County Association of Governments was instrumental in implementing this study.

Ground-water resources in western Kane County are being developed for a number of reasons, ranging from irrigation of alfalfa and other crops, to the use in slurry pipelines for transporting coal to distant power plants. Consequently, further understanding of the physical extent of the aquifers, areas of recharge, recharge and contamination potential of water in the aquifers, and ground-water quality is necessary so that future plans for development can provide adequate protection of, and minimize detrimental effects to, these aquifers and their recharge areas.

\section{Purpose and Scope}

The purpose of this report is to describe the physical extent and thickness of the principal aquifers in western Kane County, delineate recharge areas of these aquifers, and assess the potential for recharge to and contamination of water in, the aquifers. Because this study focuses on the relative importance of the principal aquifers, they are discussed in order of decreasing utilization throughout the report. More hydrologic and water-quality data are available for the Navajo aquifer than for other aquifers.

In addition, the report describes the current (1990) quality of water in the principal aquifers, particularly with respect to concentrations of dissolved solids. These data will provide the State with information to classify ground water in western Kane County in accordance with State of Utah Ground-Water-Quality Protection Regulations (Utah Department of Health, 1989).

Information on stratigraphic relations, and definition and geometry of the ground-waterflow systems of the principal aquifers are presented. The scope of the investigation did not provide for a quantitative assessment of recharge; thus, factors influencing recharge and the potential for contamination are qualitatively assessed. The report also includes a compilation of past waterquality analyses from wells and springs with analyses of water samples collected during this project.

\section{Previous Investigations}

The hydrologic system in the Navajo Sandstone in western Kane County and adjacent areas has been investigated by numerous authors, including those from the State of Utah, the U.S. Geological Survey, and Bingham Engineering. Reports generated from these studies have dealt largely with ground-water movement and lithologic characteristics of the aquifers, and include those by Goode (1964, 1966), Cordova (1981), Blanchard (1986), Bingham Engineering (1979, 1981, 1987), Freethey (1988), and Heilweil and Freethey (1992). 


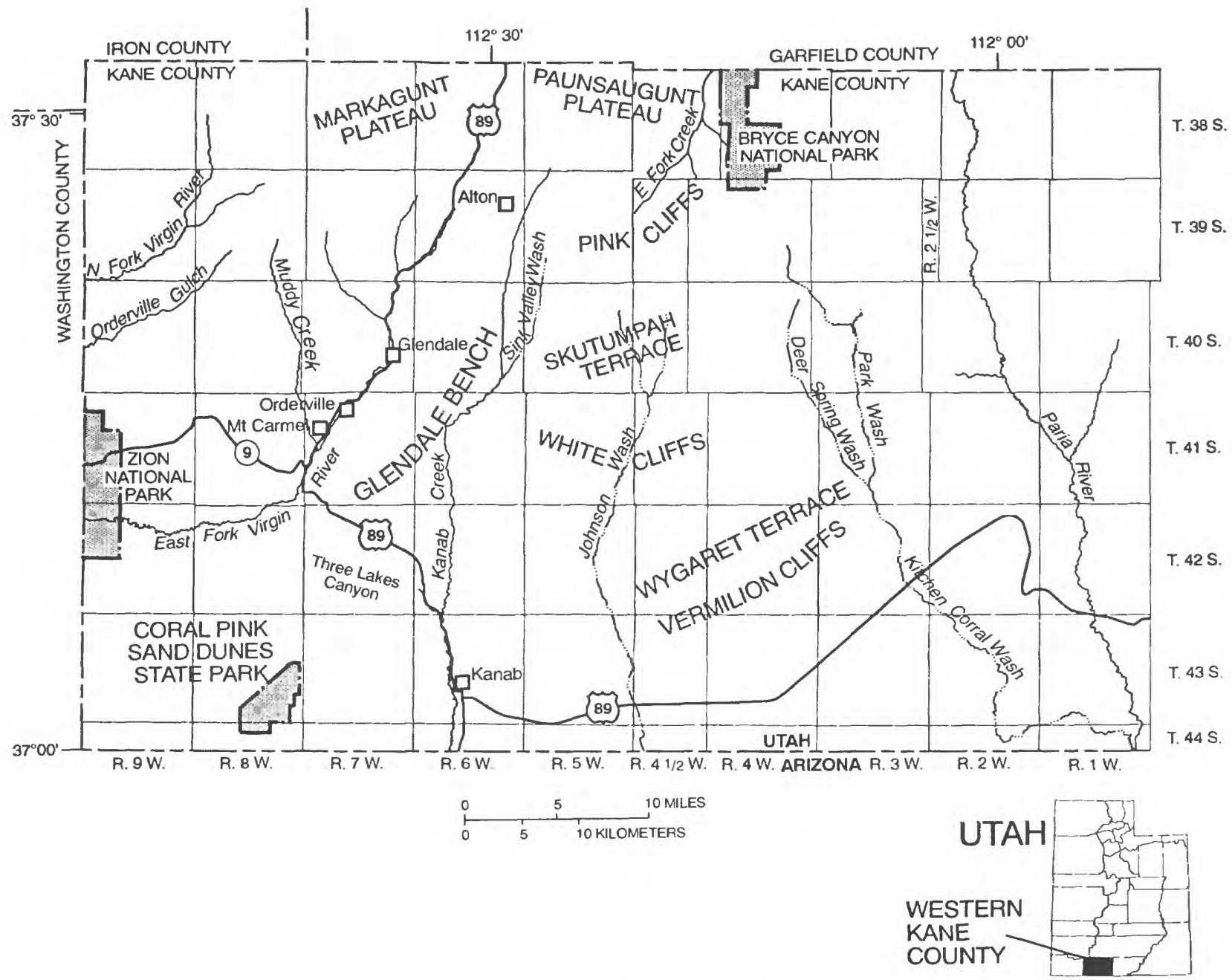

Figure 1. Location and geographic features of the study area.

Goode $(1964,1966)$ did reconnaissance studies of water resources in western Kane County. Both of these studies were designed to assess the quantity and quality of ground water in this area, especially water in the Navajo Sandstone, which might be used in the development of coal reserves. Cordova (1981) investigated ground-water quality and quantity in the upper Virgin River and Kanab Creek drainage basins of western Kane County. Blanchard (1986) studied water in the Navajo Sandstone in the Kaiparowits Plateau area of eastern Kane County, concentrating on water quality and recharge. Bingham Engineering $(1979,1981,1987)$ did a series of investigations for Utah International Corporation in the 1970's and 1980's concerning the use of ground water to slurry coal from strip mine operations. These studies focused on analysis and interpretation of aquifer tests, collection of water-quality data, and ground-water budgets. Freethey (1988) studied the geohydrology of the Navajo aquifer in western Kane County, including rates and direction of groundwater movement, recharge, and discharge. A water budget for the Navajo aquifer was developed by Heilweil and Freethey (1992), using computer techniques to simulate ground-water flow and pumping in parts of the aquifer, especially near the Sevier Fault. 


\section{Methods of Investigation}

The physical and hydrologic character of the principal aquifers in western Kane County were determined from geologic maps (Hintze, 1963, and Doelling and others, 1989), normal winter precipitation maps (U.S. Weather Bureau, 1963), and previous hydrologic studies (Cordova, 1981; Bingham Engineering, 1987; and Freethey, 1988). Physical extent and thickness of the aquifers were determined from elevations of geologic contacts and structural configuration.

In order to compute the thickness of the saturated part of the Navajo Sandstone, the elevation of the base of the Navajo Sandstone was determined by projecting the basal contact of the outcrop to a point below a particular well, using the angle and direction of dip determined from a structure contour map of the top of the Navajo Sandstone (Doelling and others, 1989, pl. 5). The elevation of the base of the formation was subtracted from the elevation of the water level in the selected well to obtain the saturated thickness. Because of the variability in the angle and direction of dip, formation contacts, and the distance of projection, the error of computed saturated thicknesses is estimated to be as much as 100 feet. Where computed saturated thickness is a negative value, true thickness is presumed to be less than 100 feet.

Potential recharge areas for the principal aquifers were delineated by overlaying maps that depicted the primary factors influencing recharge. These factors included the quantity of winter precipitation, types and extent of unconsolidated deposits, topographic slope of the outcrop surface, and the location of minor intermittent and perennial streams that could be sources of recharge. Numerous additional factors were considered important, but the limited scope of the investigation precluded mapping and using these factors in delineating recharge potential. These additional factors included thickness of soil cover; types and density of vegetative cover; evapotranspiration; and the continuity, aperture, and spacing of vertical fractures.

Delineation of areas where topographic slope was greater than or less than about 30 degrees was based on metric contour maps having a contour interval of 50 meters (164 feet). Time of travel of ground water was determined from published data for hydraulic conductivity, formation porosity, and hydraulic gradient.

Dissolved-solids concentrations in water from 44 wells and 51 springs in the principal aquifers were obtained primarily from data bases of the U.S. Geological Survey. Concentrations were derived by either summing and calculating the analyzed constituents in a water sample and/or by weighing the residue of a water sample after evaporation at $180^{\circ} \mathrm{C}$. Ground water from many sites was sampled more than once, and only the most recent (generally less than 15 years) dissolvedsolids concentrations were used for classification purposes.

During this study, seven water samples were collected from selected wells and one sample was collected from a spring. All samples were measured for temperature, $\mathrm{pH}$, and specific conductance at the well site or spring. Alkalinity titrations for determination of bicarbonate concentration for six of the eight water samples were also conducted on site. All samples were analyzed for major anions and cations, selected trace elements, organic chemicals (pesticides and volatile organic compounds), nitrate, and radionuclides (gross-alpha activity), as outlined in the State of Utah Ground-Water-Quality Protection Regulations (Utah Department of Health, 1989). 


\section{Data-Site Numbering System}

The system for identifying and locating hydrologic and geologic data sites in Utah is based on the cadastral land-survey system of the U.S. Government. An assigned number, in addition to designating a well or spring, describes its position in the land net. By the land-survey system, the State is divided into four quadrants by the Salt Lake Base Line and the Salt Lake Meridian (fig. 2). These quadrants are designated by the uppercase letters A, B, C, and D indicating respectively, the northeast, northwest, southwest, and southeast quadrants. Numbers designating the township and range follow the quadrant letter, and all three are enclosed in parentheses. The number after the parentheses denotes the section, and is followed by three letters indicating the quarter section, the quarter-quarter section, and the quarter-quarter-quarter section-equivalent to 10 acres. The lower case letters a, b, c, and d indicate respectively, the northeast, northwest, southwest, and southeast quarters of each subdivision. The number after the letters is the serial number of the wells or springs within the 10 -acre tract. The letter " $\mathrm{S}$ " preceding the serial number denotes a spring. For the half-ranges found within the study area, the letter " $R$ " precedes the parentheses. As an example, (C-40-5)11 bca-S1 indicates the first spring inventoried in the northeast quarter of the southwest quarter of the northwest quarter of section 11, T. 40 S., R. 5 W. (fig. 2).

\section{PHYSICAL SETTING}

The study area encompasses about 2,200 square miles in southwestern Utah, extending from the Utah-Arizona state line north to the Kane-Garfield County boundary (fig. 1). The western margin of the area coincides with the Washington-Kane County boundary. Notable scenic features in this region include Bryce Canyon National Park, Zion National Park, and Coral Pink Sand Dunes State Park.

\section{Geography and Climate}

The study area includes the upper drainage basins of the East Fork Virgin River, Kanab Creek, Johnson Wash, Kitchen Corral Wash, and the Paria River (fig. 1). The streams in Johnson Wash and Kitchen Corral Wash are ephemeral for much of the year, as are streams in numerous smaller drainages. Kanab Creek, the East Fork Virgin River, and the Paria River are perennial streams. A number of small communities including Glendale, Orderville, and Mt. Carmel are in the western part of the study area, primarily along the East Fork Virgin River. Kanab, the largest community in the region (population 3,100), is in the south-central part of the study area along Kanab Creek. All of these communities rely on wells and springs for water supplies. Most of the wells along Kanab Creek are municipal water sources for the city of Kanab, and those in Johnson Wash are used largely for irrigation. Fredonia, Arizona, 8 miles south of Kanab, also obtains water from wells and springs in southwestern Kane County.

The physiography of this region is characterized by three east-west-trending arcuate cliffs that are separated by relatively flat terraces (fig. 1). The southernmost Vermilion Cliffs and White Cliffs are separated by Wygaret Terrace. In many areas, the White Cliffs are as much as 500 feet in height. The northernmost Pink Cliffs are separated from the White Cliffs by Skutumpah Terrace. The Markagunt and Paunsaugunt Plateaus north of the Pink Cliffs are mildly dissected, gen- 


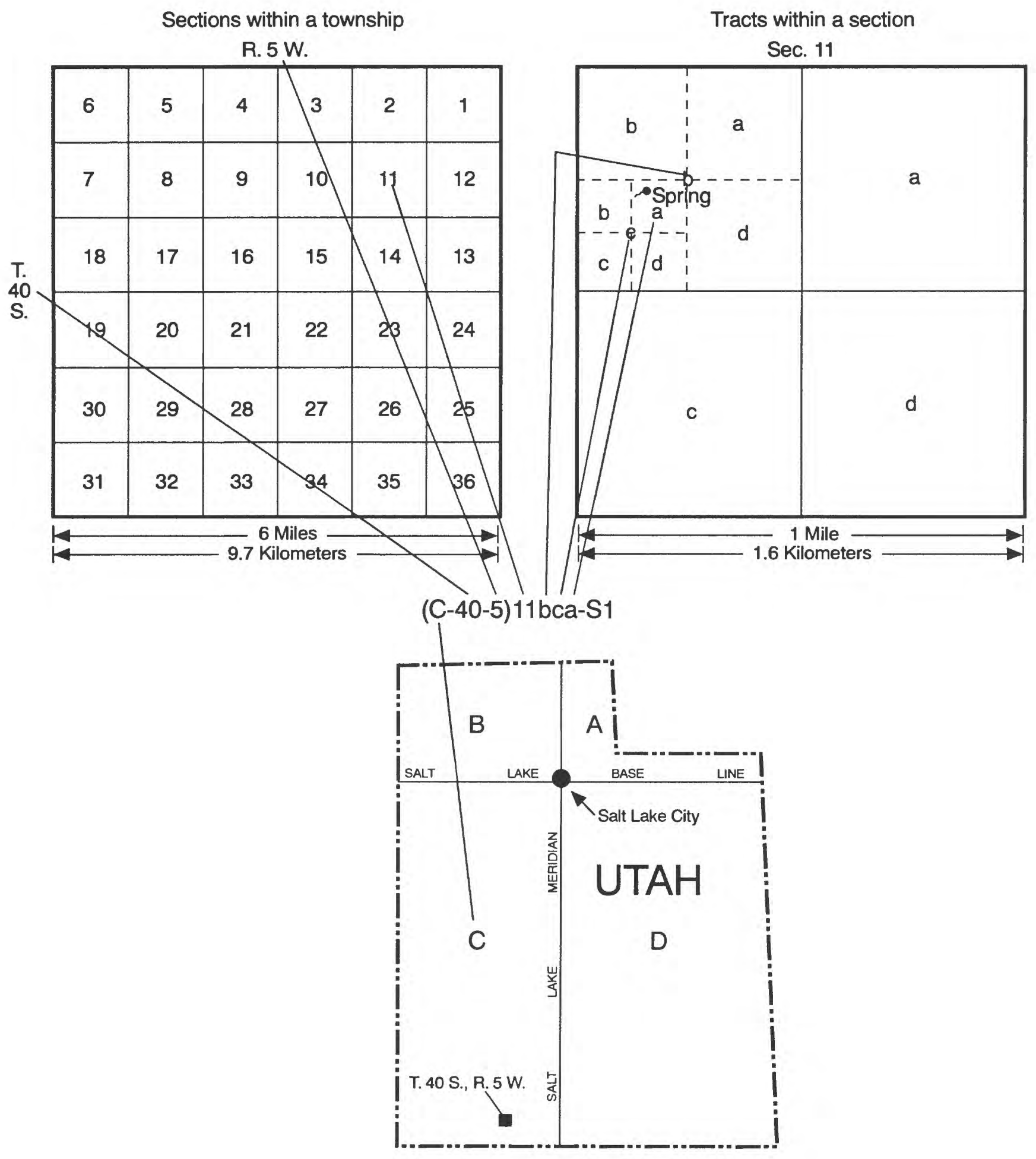

Figure 2. Numbering system for geohydrologic-data sites in Utah. 
tly rolling uplands. Total relief from south to north from the base of the Vermilion Cliffs to the tops of these plateaus is about 6,000 feet over a distance of about 30 miles.

Precipitation in western Kane County is seasonally variable and dependent on geographic location and elevation. Data from climatologic stations at Alton and Kanab indicate that average winter precipitation (October-April) ranges from less than 6 inches in the southeastern part of the area to more than 30 inches in northwestern Kane County (U.S. Weather Bureau, 1963).

\section{$\underline{\text { Geology }}$}

The study area is part of the Grand Staircase of the Colorado Plateau Physiographic Province (Stokes, 1988, p. 237). The stratigraphic sequence consists of varicolored Paleozoic, Mesozoic, and Cenozoic sedimentary rocks that generally dip north at 1 to 3 degrees, except near areas of folding or faulting, where the dip may be considerably steeper. Parts of the area have been uplifted and dissected by numerous normal faults that have subdivided the region into several structural blocks. A schematic section across part of the study area showing relative thickness and stratigraphy is presented in figure 3. A geologic map of western Kane County compiled from both Hintze (1963) and Doelling and others (1989) is shown on plate 1.

\section{Stratigraphy}

The oldest rocks that crop out in western Kane County are the Moenkopi and Chinle Formations of Triassic age (pl. 1). These rocks crop out east of Kanab in the southeastern part of Kane County and generally consist of reddish-brown mudstone, siltstone, and fine-grained to conglomeratic sandstone. A thin sequence of reddish-brown siltstone and fine-grained sandstone beds in the Moenave and Kayenta Formations of Jurassic age overlie the Triassic beds and form the base of the Vermilion Cliffs, east of Kanab.

The Navajo Sandstone of Jurassic age caps the Vermilion Cliffs and extends north to form the White Cliffs and intervening Wygaret Terrace (fig. 3 and pl. 1). Between the Sevier and Paunsaugunt Faults in the southern part of the area, the Navajo Sandstone is separated into an upper, massive unit and a lower unit by the Tenney Canyon Tongue, a shaly unit of the underlying Kayenta Formation. The lower part of the Navajo Sandstone in this area is termed the Lamb Point Tongue. Much of the Navajo Sandstone shows large-scale cross-bedding. Total thickness of the Navajo Sandstone in the study area ranges from about 1,300 to 2,200 feet, increasing from east to west. The Temple Cap Sandstone unconformably overlies the Navajo Sandstone west of the Sevier Fault (pl. 1).

The Skutumpah Terrace between the White and Pink Cliffs, including Glendale Bench to the west, consists largely of various members of the Jurassic Carmel Formation (fig. 3 and pl. 1). These members consist of siltstone, sandstone, gypsum, and shaly limestone, for a total thickness of about 700 feet. The Entrada Sandstone crops out east of the Paunsaugunt Fault.

A sequence of Cretaceous formations overlies the Jurassic rocks between Skutumpah Terrace and the Pink Cliffs (fig. 3 and pl. 1). The basal Dakota Formation consists of interbedded shale, sandstone, and conglomerate, and contains large reserves of coal. Dark-gray Tropic Shale overlies the Dakota Formation throughout the area. The Straight Cliffs, Wahweap, and Kaiparow- 


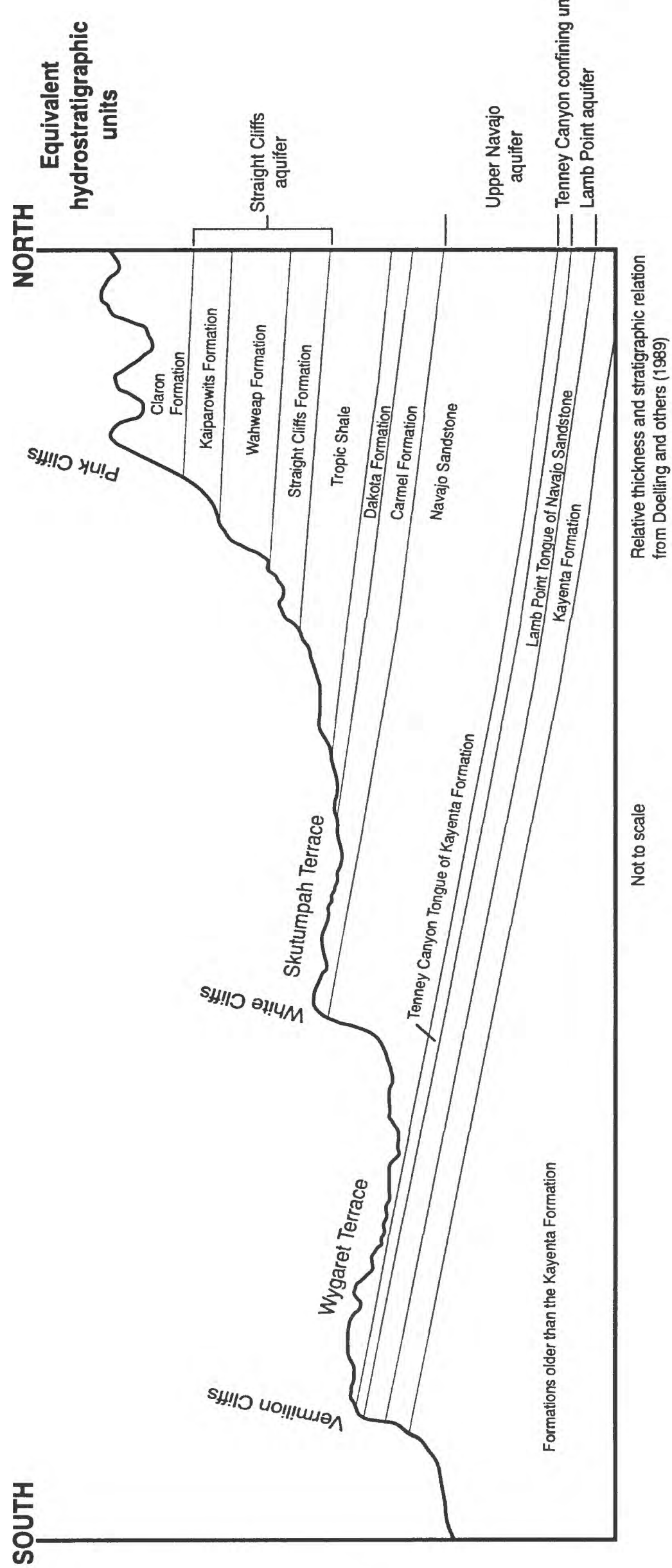

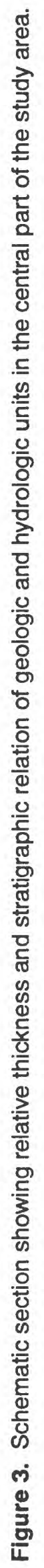


its Formations overlie the Tropic Shale and form a thick sequence of interbedded sandstone, siltstone, mudstone, and conglomerate with a combined thickness of about 2,000 feet.

The prominent Pink Cliffs in the northern part of the study area, as well as parts of the Markagunt and Paunsaugunt Plateaus, are freshwater limestone and dolomite, with lesser quantities of shale, sandstone, and conglomerate. This 1,300 -foot thick sequence of sedimentary rock is the Tertiary Claron Formation (pl. 1).

Overlying the sedimentary section described above are more recent Quaternary deposits. Volcanic eruptions have produced cinder cones and basaltic lava flows in the upstream reaches of Kanab Creek and Johnson Wash and in the northwestern part of Kane County (pl. 1). Alluvial sand and gravel is present along stream channels and washes, on terraces, and in flood plains and valleys. Deposits of alluvium, sand, and gravel are generally less than 100 feet thick. Eolian sand derived from weathering of the Navajo Sandstone is present in parts of southwestern Kane County, especially at Coral Pink Sand Dunes (pl. 1).

\section{Structure}

Normal faulting is present throughout western Kane County (pl. 1). The faults generally trend northeast to northwest, with horsts and grabens locally developed. The Sevier Fault traverses across the western part of the study area, offsetting the Navajo Sandstone into the Zion (western) and Kanab (eastern) blocks (Heilweil and Freethey, 1992, p. 12). Displacement along this fault ranges from about 100 feet in the north to as much as 2,000 feet in the south, with the downthrown block to the west. As a result of the displacement, rocks of the Carmel Formation abut against the Navajo Sandstone in the vicinity of the town of Mt. Carmel.

Other faults are coincident with major drainages and include those along Kanab Creek and Johnson Wash. Displacement along these faults within the Kayenta Formation and Navajo Sandstone is generally less than 200 feet. The Bald Knoll Fault cuts across the Skutumpah Terrace in the central part of the study area, with as much as 500 feet of displacement in the Navajo Sandstone and Carmel Formation.

The Paunsaugunt Fault trends northward across the eastern part of the study area (pl. 1). Displacement along this fault increases from about 200 feet in the south to 1,500 feet in the north, with the downthrown block to the west. The eastern boundary of the study area coincides approximately with the East Kaibab Monocline (pl. 1). This prominent northeast-trending flexure is paralleled by numerous faults that have juxtaposed older Jurassic and Triassic rocks on the west against younger Cretaceous and Jurassic rocks to the east.

\section{PHYSICAL EXTENT AND THICKNESS OF THE PRINCIPAL AQUIFERS}

The principal aquifers in western Kane County are the Navajo aquifer, the Straight Cliffs aquifer, and alluvial aquifers. Relations between the principal aquifers and their equivalent stratigraphic units are shown in figure 3. The Navajo aquifer is defined as the saturated part of the Navajo Sandstone. In the lower part of the Navajo Sandstone where the Tenney Canyon Tongue of the Kayenta Formation is present, and is a confining unit, the Navajo aquifer is divided into the 
upper Navajo and Lamb Point aquifers. The Straight Cliffs aquifer includes the Straight Cliffs, Wahweap, and Kaiparowits Formations. As no substantial confining units separate these formations, they are presumed to be hydraulically connected and considered to be a single aquifer for purposes of this report. Saturated parts of unconsolidated deposits (primarily alluvium in stream valleys) are alluvial aquifers. Outcrops of the formations that include the principal aquifers are shown in figure 4.

In general, wells and springs in the southern and eastern parts of the study area, including those in Kanab Creek and Johnson Wash, withdraw or discharge water from the Navajo aquifer, including both the upper Navajo aquifer and the Lamb Point aquifer. Most springs in the northern and northwestern parts of Kane County discharge from the Straight Cliffs aquifer. Nine wells in the study area are in unconsolidated deposits (alluvium) within and adjacent to stream channels that overlie consolidated-rock aquifers.

\section{Navajo Aquifer}

The physical extent of the Navajo aquifer is approximately the same as the physical extent of the Navajo Sandstone, which crops out from west to east between the Kane County-Washington County line and the East Kaibab Monocline (fig. 4 and pl. 1). East of the Sevier Fault, the southern boundary of the Navajo aquifer is outlined by the outcrop margin of the Navajo Sandstone. The Navajo aquifer is unconfined (exists under water-table conditions) where the Navajo Sandstone crops out and for an unknown distance north, where it is overlain by the Carmel Formation and other younger formations. The northern extent of the Navajo aquifer has not been delineated because of its considerable depth and the lack of wells penetrating the formation. Several deep wells drilled by Utah International and Utah Power and Light indicate, however, that the Navajo aquifer extends beneath overlying Jurassic, Cretaceous, and Tertiary formations, increasing in depth to the north. A well drilled in the town of Tropic, just to the northeast of the study area, penetrated the top of the Navajo Sandstone at a depth of about 2,160 feet, with water-level measurements indicating that the aquifer is confined (fully saturated) (Phillip Leslie, Leslie and Associates, written commun., 1991). A dashed line in figure 4 indicates where the top of the Navajo aquifer is about 2,000 feet below the land surface.

Between the Sevier and Paunsaugunt Faults, the Navajo aquifer is divided into the upper Navajo and Lamb Point aquifers by the Tenney Canyon Tongue, a shaly confining bed of the Kayenta Formation (pl. 1). Where the Lamb Point Tongue crops out and for a short distance to the north where it is overlain by the Tenney Canyon Tongue, the Lamb Point aquifer is unconfined. East of the Paunsaugunt Fault, the Tenney Canyon Tongue is considerably thinner and the Lamb Point aquifer is not separated from the upper Navajo aquifer.

Thickness of the Navajo aquifer (including upper Navajo and Lamb Point aquifers) is variable throughout the study area, ranging from 50 to 100 feet in areas where the aquifer is unconfined to about 2,000 feet where it is confined. Generally, thickness of the Navajo aquifer increases from south to north. Computed thicknesses of the upper Navajo and Lamb Point aquifers from selected wells are shown in figure 4.

Thickness of the Navajo aquifer at Coral Pink Sand Dunes is computed to be 600 to 700 feet, assuming a total thickness of 2,200 feet for the Navajo Sandstone. Farther north along the 
downthrown side of the Sevier Fault, saturated thickness of the sandstone increases to as much as 1,800 feet near the town of Mt. Carmel, assuming the total thickness of the Navajo Sandstone to be about 2,000 feet. In the eastern part of Zion National Park, computed thickness of the Navajo aquifer is 900 to 1,000 feet, based on a thickness of 2,200 feet for the Navajo Sandstone in this area.

East of the Sevier Fault, thickness of the upper Navajo aquifer is considerably less. Computed thickness of the upper Navajo aquifer in Three Lakes Canyon is between 200 to 250 feet. Thickness of the upper Navajo aquifer in well (C-42-5)30ada-1 between Kanab Creek and Johnson Wash is about 200 feet. In addition, thickness of the upper Navajo aquifer near the northern margin of the Navajo Sandstone outcrop in Johnson Wash is about 500 feet. In the vicinity of the Bald Knoll test well at (C-40-5)21abc-1, the total thickness of the upper Navajo and Lamb Point aquifers is about 1,700 feet (Bingham Engineering, 1981, p. 11). On the basis of available data, thickness of the Navajo aquifer east of the Paunsaugunt Fault is 50 to 100 feet and probably less than 50 feet locally.

Computed thickness of the Lamb Point aquifer in the area between the Sevier Fault and Kanab Creek, is about 100 feet. In Johnson Wash, thickness of the Lamb Point aquifer increases to about 300 feet. Near the Paunsaugunt Fault, thickness of the Lamb Point aquifer is estimated to be less than 100 feet.

Areas where the Navajo Sandstone may be unsaturated are along the edge of outcrops, in isolated erosional remnants, and along fault boundaries where uplift has been substantial. Well (C-42-4) 3bac-1, drilled by Utah International just east of the Paunsaugunt Fault, penetrated the entire thickness of the Navajo Sandstone without encountering a saturated zone (Freethey, 1988, p. 28).

\section{Straight Cliffs Aquifer}

The physical extent of the Straight Cliffs aquifer, like that of the Navajo aquifer, is interpreted to be approximately the same as the physical extent of the geologic formations that make up the aquifer (fig. 4 and pl. 1). From oldest to youngest, these include the Straight Cliffs, Wahweap, and Kaiparowits Formations. Where these formations crop out, the aquifer is presumed to be unconfined.

Few wells have been completed in the Straight Cliffs aquifer, and little is known regarding its physical extent or the direction of ground-water movement within the aquifer. As with the $\mathrm{Na}$ vajo aquifer, the southern extent of the Straight Cliffs aquifer is delineated by the outcrop margin of the formations, whereas the northern extent of the aquifer is unknown where the formations dip beneath the overlying Claron Formation (fig. 4).

Numerous springs discharge from the Straight Cliffs Formation and locally, from the Wahweap and Kaiparowits Formations. Goode (1966, p. 30) showed that springs issuing along the base of formation outcrops in dipping sandstones such as those discharging from the Straight Cliffs Formation, indicate saturation of the formation downdip, where overlain and underlain by confining units. Consequently, it is probable that at some distance to the north as elevation of the aquifer decreases, the entire sequence of formations included in the Straight Cliffs aquifer is saturated. 

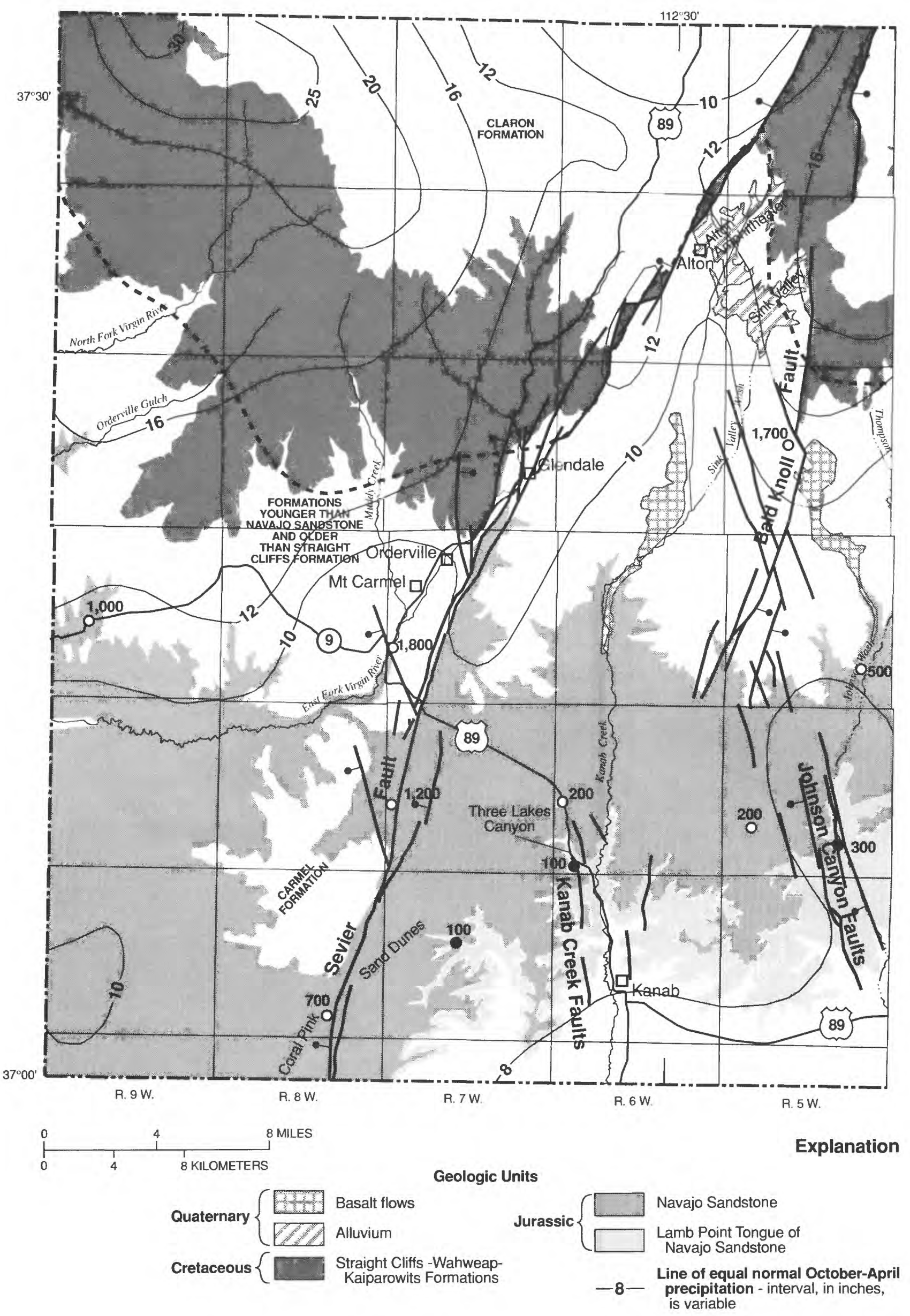

Figure 4. Outcrop of formations that include the principal aquifers, saturated thickness of the upper 


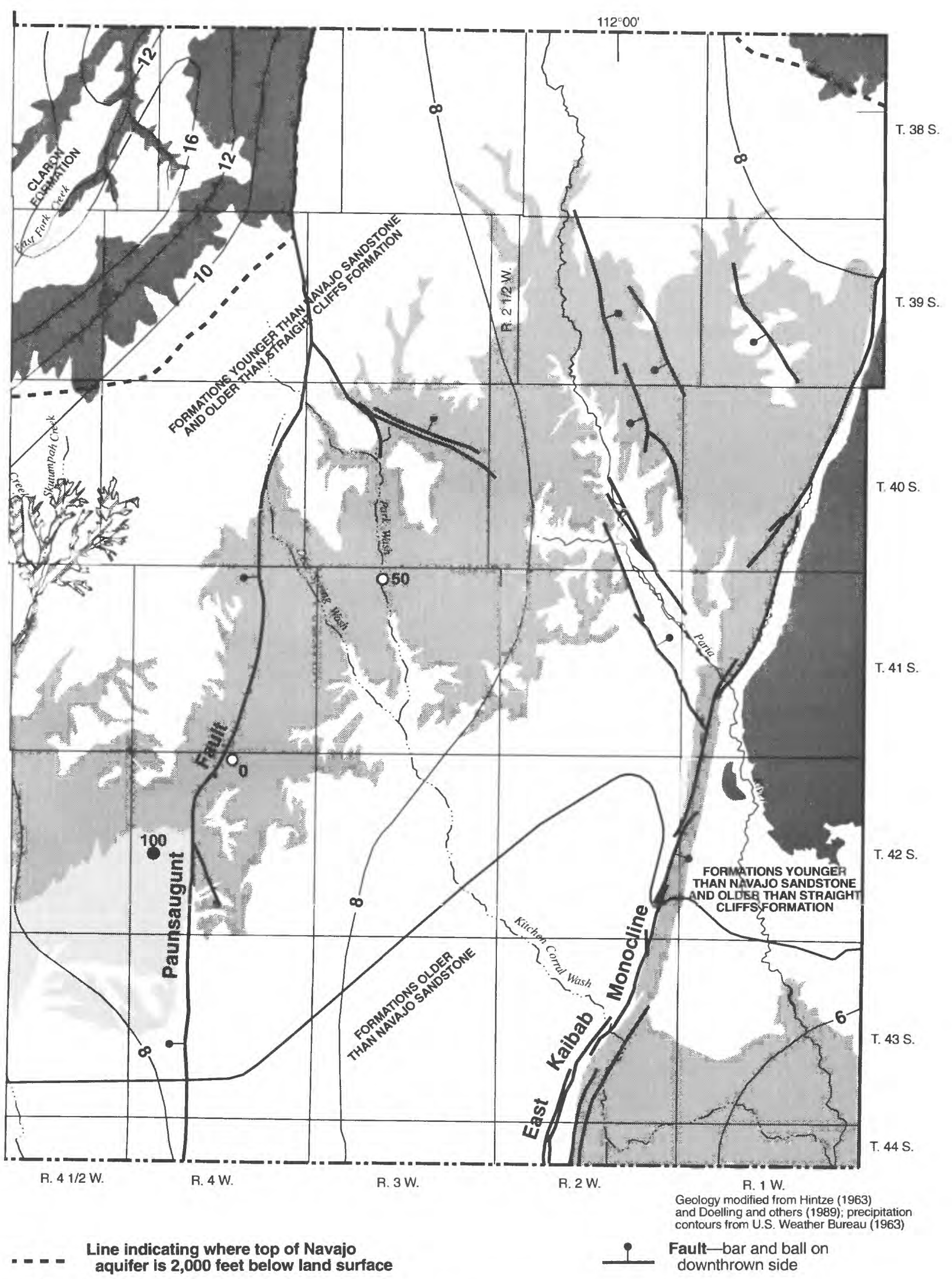

200 Well with saturated thickness of Navajo

aquifer or upper Navajo aquifer, in feet; rounded to nearest 50 feet

100 Well with saturated thickness of Lamb Point aquifer, in feet; rounded to nearest 50 feet

Navajo and Lamb Point aquifers at selected wells, and winter precipitation rates in western Kane County. 
From limited water-level data, it appears that areas where the Straight Cliffs, Wahweap, and Kaiparowits Formations crop out are the main recharge areas for the Straight Cliffs aquifer. Recharge water at the outcrop presumably moves to the south to discharge at numerous springs at the contact with the underlying Tropic Shale. Farther to the north, the direction of ground-water movement in the Straight Cliffs aquifer is unknown. Thickness of the Straight Cliffs aquifer probably ranges from less than 100 feet near the erosional edge of the outcrops of the formations to about 2,000 feet in the north, where all of the formations are presumed to be fully saturated.

\section{Alluvial Aquifers}

Alluvial aquifers are present along ephemeral stream channels on Skutumpah Terrace between the Pink and White Cliffs and on Wygaret Terrace between the White and Vermilion Cliffs. Alluvial aquifers are present along Thompson Creek and Skutumpah Creek and in unconsolidated deposits that cover broad valley floors in Alton Amphitheater and Sink Valley (fig. 4). Alluvial aquifers in these areas are underlain by the Carmel Formation and Tropic Shale, which probably impede downward migration of ground water. Aquifers in alluvial materials are generally less than 100 feet thick, unconfined, and of limited areal extent.

Basaltic lava flows cover large areas of northwestern Kane County and parts of upper Kanab Creek and Johnson Wash (fig. 4 and pl. 1). Although in some areas outside the study area basalt aquifers produce large quantities of water where the basalt is thick, basalt in western Kane County is generally less than 100 feet thick and presumed to be largely unsaturated. Basaltic rocks now fill pre-existing drainages that likely contain alluvial deposits. As basalt tends to be highly permeable, most precipitation probably infiltrates rapidly through the basalt and into underlying alluvial aquifers.

\section{RECHARGE AREAS AND RELATIVE POTENTIAL FOR RECHARGE TO THE PRINCIPAL AQUIFERS}

The recharge areas for the principal aquifers in western Kane County generally consist of the outcrops of the formations that make up the aquifers (fig. 4). A narrow band immediately north of the outcrop areas (too small to be shown at map scale) also is considered part of the recharge area because the overlying formations are thin enough to permit some vertical infiltration.

Recharge to the principal aquifers is by infiltration of precipitation in the outcrop areas, including infiltration through unconsolidated materials, leakage of ground water from overlying formations, seepage along faults and joints, losses from ephemeral and perennial streams, and possibly by lateral or upward movement of ground water from other formations (fig. 5). Major factors that influence the quantity of water recharging the principal aquifers include type, extent, and hydraulic conductivity of unconsolidated deposits overlying the consolidated-rock aquifers; quantity of winter precipitation; evapotranspiration; type and density of vegetative cover; thickness of soil cover; topographic slope; and the continuity, aperture, and spacing of vertical fractures.

In order to determine the potential for recharge to the principal aquifers, the types of recharge and major factors influencing recharge were examined for each of the aquifers. Because the recharge areas for the principal aquifers are at different elevations and have different magnitudes 


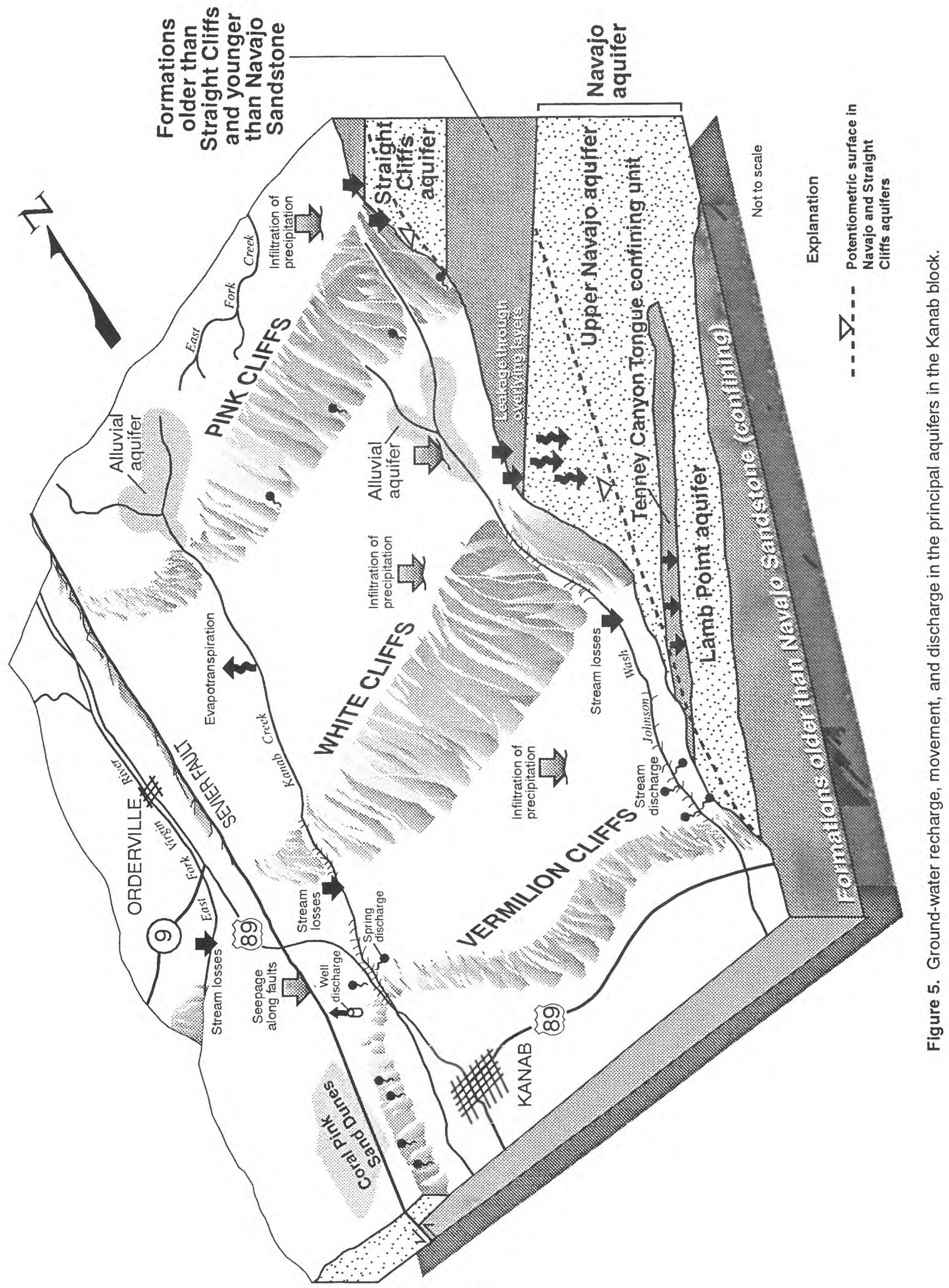


for factors influencing recharge potential, the recharge potential for each aquifer is described separately in the following discussion.

For purposes of mapping recharge potential, the type and extent of unconsolidated deposits overlying the outcrop, the quantity of winter precipitation on the outcrop, and the slope of the outcrop were evaluated. For the Navajo aquifer, recharge from ephemeral and perennial streams where the potentiometric surface is below the elevation of the stream was also considered. The relative recharge potential for each of the principal aquifers is shown on plate 1.

\section{Navajo Aquifer}

Recharge to the Navajo aquifer by infiltration of precipitation takes place in the southern part of the study area where the Navajo Sandstone crops out (pl. 1). Some of the precipitation that falls on these outcrops infiltrates directly into the rock or runs off into nearby stream channels or washes. Storm intensity influences the quantity of infiltration. Intense storm activity results in a greater quantity of runoff, especially on steeper slopes, whereas low intensity, long duration rainfall or gradually melting snow allows more of the precipitation to infiltrate directly. Soil profiles, if well developed, impede runoff and promote infiltration, but vegetation that is present causes some of the recharge to be lost through evapotranspiration. Outcrop areas with the greatest potential for infiltration of recharge from precipitation are characterized by undulating, low relief topography, as on Wygaret Terrace. In these areas, numerous pools tend to form in natural, closed depressions after considerable rainfall, allowing diffuse infiltration through the sandstone. Areas where the topography is steep, especially cliff escarpments, have the greatest runoff and least potential for recharge by infiltration of precipitation (pl. 1).

Recharge to the Navajo aquifer also takes place by downward leakage of ground water through overlying formations (fig. 5). Leakage from the Carmel Formation is a likely source of recharge to the Navajo aquifer, especially where the Carmel Formation is relatively thin, as along outcrop margins. East of Zion National Park where the Carmel Formation is more than 1,000 feet thick, leakage through fractures appears to provide pathways for recharge to the Navajo aquifer (Cordy and others, U.S. Geological Survey, written commun., 1990). In addition, dissolution of salts in the Carmel Formation locally enhances vertical hydraulic conductivity and potential recharge to the Navajo aquifer (Blanchard, 1986, p. 27).

A probable pathway of recharge to the Navajo aquifer is seepage downward and along joints and faults (fig. 5 and pl. 1). Fracturing is prevalent throughout the Navajo Sandstone in areas of outcrop and where it is overlain by unconsolidated deposits. Because of the considerable thickness of the Navajo Sandstone, most of the offset from normal faulting has been confined to the formation. Other faults, such as those in the Bald Knoll area, are in the overlying Carmel Formation (pl. 1), but probably extend deep enough to facilitate recharge to the Navajo aquifer. Faults and joints in the Tenney Canyon Tongue are probably the most effective pathway for recharge to migrate from the upper Navajo aquifer into the Lamb Point aquifer, in areas where these aquifers are differentiated (fig. 5). Faults in consolidated rock beneath alluvium in the lower reaches of Johnson Wash also may facilitate recharge to the Lamb Point aquifer.

Recharge potential of fractured rock is dependent on the continuity, aperture, and spacing (density) of fractures. Shallow fractures may only influence the direction of surface runoff, rather 
than channel water into the aquifer. Closely spaced fractures divert recharge more effectively than isolated fractures and are likely to be more interconnected. Although many fractures do not extend for any substantial horizontal distance, major fractures may penetrate through several hundred feet of rock, enabling rapid recharge into the otherwise relatively impermeable sandstone. Fractures that were open initially may have been filled by sand and other wind-blown materials, or cemented closed, impeding downward movement of recharge water. Where Coral Pink Sand Dunes overlie the Sevier Fault (fig. 5 and pl. 1), recharge to the Navajo aquifer may be enhanced at the contact between sand and bedrock, if the fault zone is permeable.

Recharge may be downward along and also across fault zones or downward along but not across fault zones, depending on the permeability of, and the offset along, the fault zone. Hypothetically, hydraulic connectiveness is more likely along parts of the fault zone where the aquifer has not been totally offset (Heilweil and Freethey, 1992, p. 15).

Surface water that originates in the northern part of the study area either from spring discharge or precipitation (runoff) flows in a southerly direction and enters washes and canyons developed in outcrops of the Navajo Sandstone. Some of this water probably leaks downward through alluvium in the stream channels and into the underlying Navajo aquifer in some areas (fig. 5). Major surface drainages such as Johnson Wash and Kitchen Corral Wash contain ephemeral streams that flow only after substantial rainfall from intense storms and rapid snowmelt. Where these streams are above the level of the potentiometric surface in the Navajo aquifer, as in the upper parts of these drainages, surface water may recharge the underlying aquifer (Blanchard, 1986, p. 27 and 29). In the downstream parts of the drainages, however, the level of the potentiometric surface is probably above the level of the streams, and these areas function as discharge points (fig. 5). In Johnson Wash, leakage from alluvial aquifers may recharge the upper Navajo aquifer upstream from the Tenney Canyon Tongue outcrop. Downstream from the Tenney Canyon Tongue outcrop, the Lamb Point aquifer discharges water. Goode $(1964$, p. 41) noted that springs issuing from the Lamb Point Tongue below the Tenney Canyon outcrop would probably provide perennial flow to this part of Johnson Wash if flow from these springs were not diverted.

Lateral movement of ground water from outside the study area or upward movement from underlying aquifers is difficult to quantify and subject to many variables. Across the northern part of the study area, limited water-level data indicate that ground water flows away from, rather than toward, outcrop areas. Ground-water flow to the west discharges into the Vịirgin River, and ground-water flow in the eastern part of the study area discharges into the Paria River. In addition, major faults subdivide western Kane County into structural blocks that are assumed to be hydraulically connected only along parts of fault zones (Heilweil and Freethey, 1992, p. 12). Nonetheless, the Navajo Sandstone in the Paria Plateau, southeast of the study area in Arizona, is partly recharged by upward flow from the underlying Kayenta Formation (Blanchard, 1986, p. 27).

Unconsolidated deposits overlying the Navajo Sandstone form a particularly important pathway of recharge to the Navajo aquifer. The effects of unconsolidated deposits on recharge vary with areal extent, thickness, and lithologic character of the deposits. These deposits consist of a variety of well- to poorly sorted materials, including windblown dune sand, mixed eolian sand and alluvium, alluvium within stream channels, and gravels on terraces and pediments. Most unconsolidated deposits are less than 100 feet thick, but locally, may be of considerable areal extent. 
Total outcrop area of the Navajo Sandstone in the study area is about 460 square miles. Of this area, about 18 square miles are overlain by eolian sand. These deposits are present mostly in the southwestern part of the outcrop area (pl. 1; N8). Eolian sand consists of fine-grained, wellsorted and well-rounded particles with porosity values from 25 to 50 percent (Heath, 1989, p. 7). As a result, precipitation rapidly percolates through these deposits rather than evaporating or running off and subsequently seeps into the underlying Navajo Sandstone. Ground water that is not able to seep into the Navajo Sandstone beneath these deposits due to relative differences in permeability, probably moves laterally to discharge as springs along dune margins. Discharge from these springs is small, however, and most water evaporates or is absorbed into the sandstone within a short distance of the discharge point.

Major deposits of mixed eolian sand and alluvium cover about 110 square miles or almost 25 per cent of the total outcrop area of the Navajo Sandstone. These deposits are present mainly west of the Sevier Fault, and present as isolated patches throughout the outcrop area, particularly east of the Paunsaugunt Fault (pl. 1; N5, N7). Deposits of mixed eolian sand and alluvium vary in extent over time as a result of shifting wind patterns.

Alluvial deposits are estimated to cover about 60 square miles of the total outcrop area of the Navajo Sandstone. Parts of the outcrop band from Kanab Creek to the Paunsaugunt Fault are covered with alluvial deposits, but outcrops of the Lamb Point Tongue of the Navajo Sandstone are only locally covered by these deposits because of the narrow outcrop band. West of the Sevier Fault, alluvium is not confined within stream drainages and covers broad flood plains over outcrops of the Navajo Sandstone (pl. 1; N4, N6).

Hydraulic conductivity influences the rate at which water will move through unconsolidated deposits, and it is affected by lithologic variations within the deposits. Overall. eolian sand is more permeable than mixed eolian sand and alluvium, which in turn, is more permeable than alluvium. Hydraulic conductivity of a winnowed sand, as in a dune field, exceeds 1 foot per day and may be as much as 100 feet per day (Heath, 1989, p. 13). In contrast, alluvial deposits consisting of variable mixtures of clay, silt, sand, and gravel have hydraulic-conductivity values less than 10 feet per day and often less than 0.1 foot per day. In addition, deposits laid down by water are usually well stratified, with alternating layers of clay, silt, and sand. Consequently, hydraulic conductivity in the vertical direction tends to be smaller, often by several orders of magnitude, than hydraulic conductivity in the horizontal direction.

The quantity of recharge to the Navajo aquifer is also dependent, in part, on thickness of the unconsolidated cover. Because thickness of eolian sand and alluvium is variable over outcrop areas, capacity for ground-water storage also probably varies. Therefore, 10 feet of eolian sand will probably have less storage capacity than 30 feet of eolian sand, although actual rates of recharge from the sand to the aquifer may be similar.

Outcrops of the Navajo Sandstone typically receive 8 to 10 inches of winter precipitation (October - April) throughout the entire area (fig. 4). Evapotranspiration rates are greatest along the southern and eastern parts of the study area at lower elevations, where normal winter precipitation averages only 6 to 8 inches. According to Jeppson and others (1968, fig. 25), potential evapotranspiration rates are as much as 30 inches per year south of the White Cliffs. At lower elevations (less than 7,500 feet above sea level), more dense vegetation is generally found only near springs or 
seeps and along ephemeral streams. This vegetation typically includes pheatophytes such as meadowgrass, saltcedar, and rabbitbrush. Seeps at the contact between the Navajo Sandstone and the shaly Tenney Canyon Tongue are often delineated by distinct zones of phreatophyte growth, especially in Kanab Canyon. The most effective means of recharge to aquifers in areas where evapotranspiration exceeds precipitation is by direct infiltration of precipitation into alluvial and eolian deposits that lack vegetative growth. In these areas, precipitation rapidly percolates downward through unconsolidated materials before it is lost to transpiration by plants and evaporation at the land surface.

The relative potential for recharge to the Navajo aquifer was based on topographic slope, quantity of winter precipitation, and lithologic character of the overlying veneer of unconsolidated deposits (pl. 1). Determining the quantitative influence of topographic slope was not within the scope of this study. Thus, for the purpose of assessing recharge potential, it was assumed that areas with a topographic slope greater than 30 degrees have little or no potential for infiltration of recharge because of the tendency for rapid runoff to a less steep area. A quantitative assessment of the effects of vegetation, soil cover, and evapotranspiration also was not made because it was not within the scope of this study. In addition, surface fractures have not been systematically mapped in the study area. Nonetheless, recharge potential to the Navajo aquifer may be substantially enhanced in the vicinity of fracture zones.

Recharge categories are defined and listed below in order of increasing recharge potential. These recharge categories are generalized and may not be accurate for specific locations. The category representing the least recharge potential is identified as category N1. The category representing the greatest recharge potential is identified as category N9. A brief description of each category follows:

N1 - Area where average topographic slope is greater than 30 degrees.

N2 - Area where average topographic slope is less than 30 degrees, normal winter precipitation is less than 8 inches, and no unconsolidated materials cover the Navajo Sandstone.

N3 - Area where average topographic slope is less than 30 degrees, normal winter precipitation is greater than 8 inches, and no unconsolidated materials cover the Navajo Sandstone.

N4 - Area where average topographic slope is less than 30 degrees, normal winter precipitation is less than 8 inches, and the Navajo Sandstone is covered with a veneer of alluvium.

N5 - Area where average topographic slope is less than 30 degrees, normal winter precipitation is less than 8 inches, and the Navajo Sandstone is covered with a veneer of mixed eolian and alluvial material.

N6 - Area where average topographic slope is less than 30 degrees, normal winter precipitation is greater than 8 inches, and the Navajo Sandstone is covered with a veneer of alluvium. 
N7 - Area where average topographic slope is less than 30 degrees, normal winter precipitation is greater than 8 inches, and the Navajo Sandstone is covered with a veneer of mixed eolian and alluvial material.

N8 - Area where average topographic slope is less than 30 degrees, normal winter precipitation is greater than 8 inches, and the Navajo Sandstone is covered with a veneer of eolian deposits.

N9 - Area where a perennial stream traverses the Navajo Sandstone and the potentiometric surface of the Navajo aquifer is below the elevation of the stream.

\section{Straight Cliffs Aquifer}

Recharge by infiltration of precipitation takes place in the northern part of the study area on outcrops of the Straight Cliffs, Wahweap, and Kaiparowits Formations (pl. 1). The outcrop area of the Wahweap Formation is considerably greater in extent than those of the Straight Cliffs or Kaiparowits Formations. Precipitation that falls on these outcrop areas infiltrates directly into the ground or runs off into nearby stream channels. Juniper and pinyon pine are uniformly distributed and a considerable soil cover has developed, which impedes runoff and promotes infiltration, but moisture is also lost through evapotranspiration. Outcrop areas with the greatest potential for infiltration of recharge from precipitation are characterized by relatively flat to gently sloping surfaces. As with the Navajo Sandstone, areas where the topography is characterized by cliff escarpments have the greatest runoff and least potential for recharge by infiltration (pl. 1).

Recharge to the Straight Cliffs aquifer also takes place by downward leakage of ground water from overlying formations (fig. 5). Recharge to the upper part of this aquifer (Kaiparowits Formation) may originate from the overlying Claron Formation, which is locally cavernous (Goode, 1966, p. 30). Infiltration of precipitation into the Wahweap Formation is interpreted to contribute to the discharge of springs issuing from the Straight Cliffs Formation because the outcrop area of the Wahweap Formation is considerably greater in extent and receives more precipitation than the outcrop area of the Straight Cliffs Formation. In the northwestern part of the study area, leakage through basalt flows also probably recharges the Wahweap Formation.

Faults and joints provide additional avenues for recharge of precipitation to the Straight Cliffs aquifer. Major fault zones including the Bald Knoll, Paunsaugunt, and Sevier have truncated and offset parts of the Straight Cliffs aquifer (pl. 1), potentially enhancing downward infiltration of water along zones of greater hydraulic conductivity.

Infiltration of recharge from precipitation through unconsolidated deposits covering the Straight Cliffs aquifer does not appear to be an important factor. No sizeable areas of eolian sand or alluvial materials have been mapped over outcrop areas of the Straight Cliffs, Wahweap, or Kaiparowits Formations.

Areas where the Straight Cliffs, Wahweap, and Kaiparowits Formations crop out are characterized by 10 to 16 inches of winter precipitation except in the extreme northwestern part of the outcrop area, which is characterized by 20 to 30 inches of winter precipitation (fig. 4). The largest quantity of precipitation, in the form of snow during the winter and thunderstorms during the summer, falls at the highest elevations (7,500 to 9,000 feet). At high elevations, the smallest recharge 
rates are during the winter and the largest recharge rates are during the spring, following snowmelt. In addition, snowmelt at high elevations provides more direct infiltration into the subsurface than rain from summer thunderstorms, which tends to run off rapidly. According to Jeppson and others (1968, fig. 25), potential evapotranspiration rates are less than 18 inches per year in northern Kane County. Consequently, precipitation exceeds evapotranspiration over much of the outcrop area of the Straight Cliffs, Wahweap, and Kaiparowits Formations.

The relative potential for recharge to the Straight Cliffs aquifer is based on topographic slope and the quantity of winter precipitation that falls on the recharge areas (pl. 1). As with the Navajo aquifer, it is assumed that areas with a topographic slope greater than 30 degrees have little or no potential for infiltration of recharge. The relative recharge categories are defined as follows:

S1- Least potential - Area where average topographic slope is greater than $\mathbf{3 0}$ degrees.

S2- Intermediate potential - Area where normal winter precipitation is less than 16 inches and average topographic slope is less than 30 degrees.

S3- Greatest potential - Area where normal winter precipitation is more than 16 inches and average topographic slope is less than 30 degrees.

\section{Alluvial Aquifers}

The recharge areas for alluvial aquifers in Alton Amphitheater, Sink Valley, Skutumpah Creek, Thompson Creek, and Johnson Wash are primarily the areas where alluvial deposits are present (fig. 4 and pl. 1). Recharge to alluvial aquifers is from precipitation directly infiltrating into these deposits, from perennial and ephemeral streams that lose water through the stream beds, and from streams at flood stage that lose water into terraces adjacent to the stream channels.

Secondary recharge takes place where alluvial materials in washes have been partly covered by basalt flows, as in the upstream reaches of Kanab Creek and Johnson Wash (fig. 4). Basalt flows are generally porous enough that recharge percolates rapidly downward along fractures and permeable zones to the underlying alluvial materials.

Although fault zones are mapped in parts of many drainages, particularly Johnson Wash, faults and joints are interpreted to be present only in the underlying consolidated rock. Consequently, they are not believed to be effective in recharging alluvial aquifers.

Recharge to alluvial aquifers is partly intercepted by phreatophytes. In addition, phreatophytes take water directly from the shallow water table, part of which is subsequently lost through evapotranspiration. Evapotranspiration rates in Sink Valley from meadowgrass are about 1.5 feet per year, whereas rates in Johnson Wash are estimated to be about 4 feet per year (Cordova, 1981, table 12).

The relative potential for recharge to alluvial aquifers is based only on the quantity of winter precipitation that falls directly on these areas (pl. 1). Evaluating the recharge potential of ephemeral streams is difficult. Topographic slope is not a factor in the recharge potential of alluvial aquifers. The two categories of recharge potential for alluvial aquifers are:

A1- Least potential - Area where normal winter precipitation is less than 10 inches.

A2- Greatest potential - Area where normal winter precipitation is 10 to about 16 inches. 


\section{POTENTIAL FOR CONTAMINATION OF GROUND WATER IN RECHARGE AREAS}

The potential for contamination of the principal aquifers in western Kane County is greatest in areas of recharge. Most recharge to the principal aquifers takes place over outcrop areas of the formations that contain the aquifers. Ground water moves from areas of recharge downgradient to areas or points of discharge. Points of discharge include major streams, wells, and springs (fig. 5). Contamination of the principal aquifers in recharge areas likewise, would migrate toward points of discharge and could affect water quality.

\section{Navajo Aquifer}

Potential contamination of the Navajo aquifer is most likely along major roads traversing the outcrop area of the Navajo Sandstone, particularly parts of U.S. Highway 89 north of Kanab (fig. 6). Potential spills along this highway could enter the upper Navajo aquifer by direct infiltration, by leakage from overlying unconsolidated deposits, or possibly by flow along faults. A large spill along this highway north of Three Lakes Canyon, may migrate downgradient toward public-supply wells producing water from the upper Navajo aquifer in Three Lakes Canyon. Contaminated water from point-source accidents along Johnson Wash could infiltrate downward into the upper Navajo aquifer or seep along faults into the Lamb Point aquifer, in which most irrigation wells are completed.

Potential contamination of the Navajo aquifer is also possible from highway spills along U.S. 89 along the East Fork Virgin River and from in situ contamination near the communities of Mt. Carmel and Orderville (fig. 6). Seepage investigations by Heilweil and Freethey (1992, p. 18) indicate that the upper reaches of the East Fork Virgin River are recharge areas, and therefore, the Navajo and other aquifers underlying these areas may be susceptible to contamination. Potential contamination in the vicinity of Alton Amphitheater could enter the upstream reaches of Kanab Creek and possibly enter the Navajo aquifer where Kanab Creek crosses outcrops of the Navajo Sandstone (pl. 1).

Ground water in the upper Navajo aquifer generally moves laterally (east and west) from outcrop areas toward major incised drainages, particularly Kanab Creek and Johnson Wash (fig. 6), based on observations and studies by Goode (1964), Bingham Engineering (1987), Freethey (1988), and Heilweil and Freethey (1992). Limited well data for the area north of Skutumpah Terrace precludes detailed interpretations of ground-water-flow directions, although measurements from wells in the Johnson Wash area and at Bald Knoll indicate a decrease in water-level elevations from south to north (Freethey, 1988, p. 19). Where the Navajo Sandstone crops out and data are available, it appears that ground-water divides in the Navajo aquifer coincide fairly closely with surface-water divides.

Water-level measurements in the Lamb Point aquifer in the Kanab block indicate that ground water moves in about the same directions as that in the overlying upper Navajo aquifer, migrating from outcrop areas where recharge takes place, toward major canyons along which springs discharge (Freethey, 1988, pl. 2). A comparison of water levels in both the upper Navajo and Lamb Point aquifers shows differences of 50 to 180 feet in the area between Johnson Wash and Kanab 


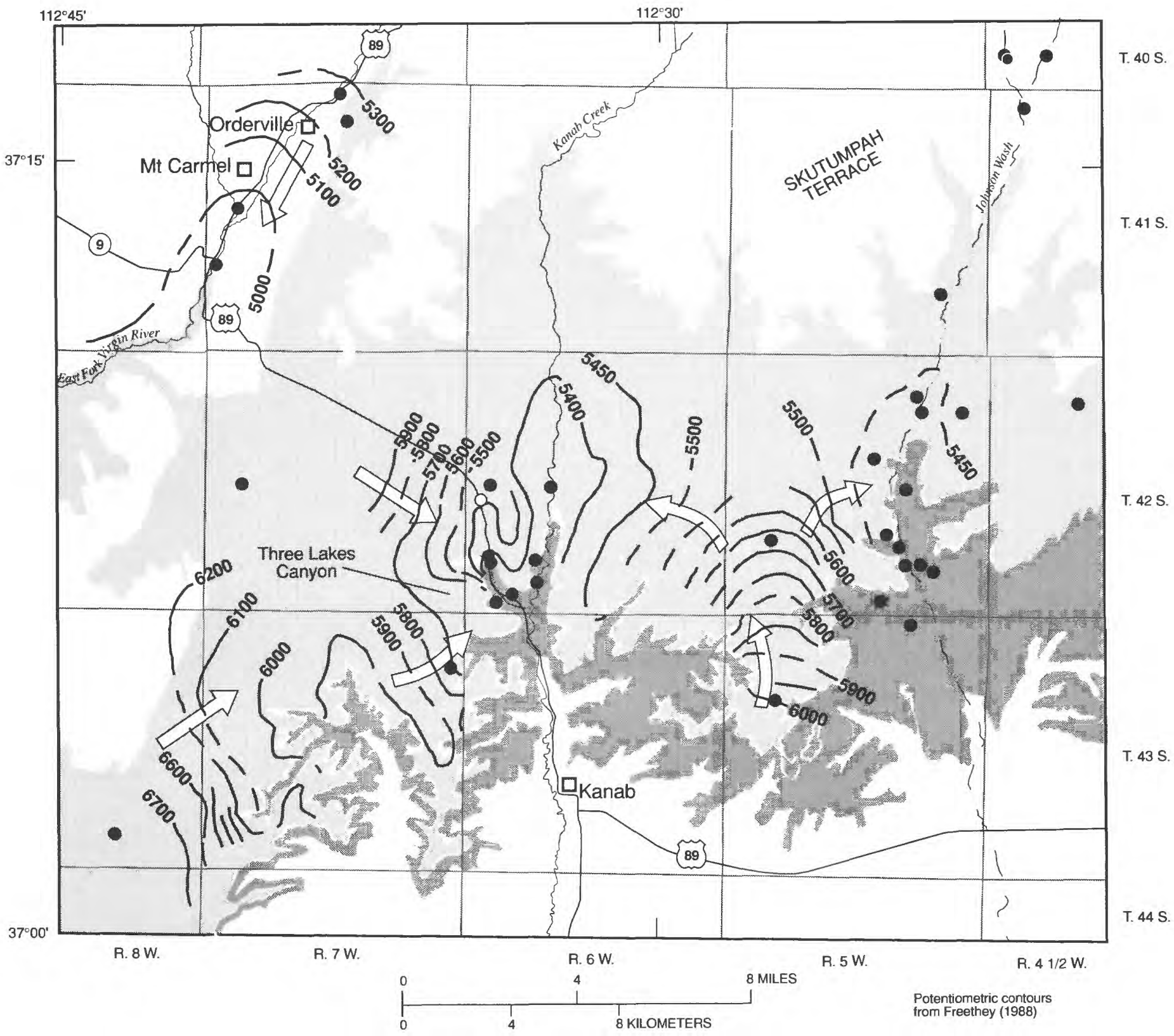

\section{Explanation}

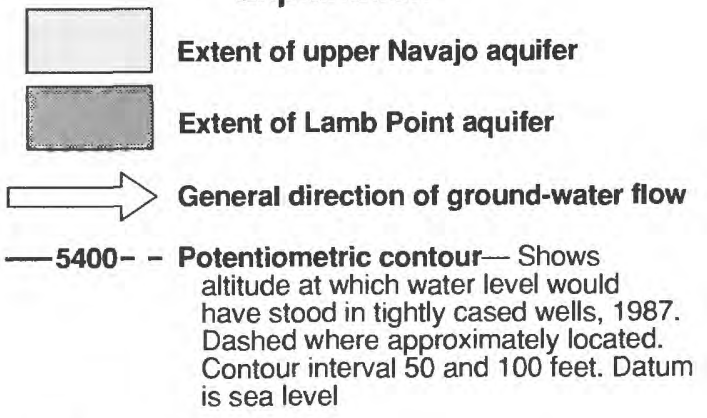

- Well

O Kanab city Mace No. 2 well

Figure 6. Potentiometric surface and general direction of ground-water flow in the upper Navajo aquifer. 
Creek, indicating a downward component of ground-water flow (Heilweil and Freethey, 1992, p. 15-16).

Velocity of ground-water flow to wells downgradient from recharge areas in the Navajo and other aquifers can be estimated using certain measured and estimated hydrologic properties, which can then be substituted into a modified Darcy equation. These parameters include hydraulic conductivity, effective porosity, and hydraulic gradient.

Hydraulic conductivity is defined as the volume of water that will move through a unit cross section of the formation in unit time under a unit hydraulic gradient (Heath, 1989, p. 12). Hydraulic conductivity is measured in both vertical and horizontal directions, and values for vertical hydraulic conductivity are generally smaller than values for horizontal hydraulic conductivity. This property is particularly important with respect to rates of recharge and velocity of ground-water flow through aquifers. Analyses of hydraulic conductivity on outcrop cores collected from the Navajo Sandstone by Uygur (1980) and Cordova (1981, table 6) indicated horizontal hydraulic conductivity ranging from 0.12 to 6.1 feet per day and vertical hydraulic conductivity ranging from 0.10 to 5.0 feet per day. Hydraulic-conductivity values from outcrop samples obtained from the Lamb Point Tongue ranged from 0.002 to 4.2 feet per day in the horizontal direction and 0.005 to 2.2 feet per day in the vertical direction.

Hydraulic conductivity varies with lithologic texture such as cross-bedding and degree of cementation. Larger hydraulic conductivity values are generally caused by fracturing. Results of an aquifer test at a Johnson Canyon well by the U.S. Geological Survey in 1977 (Bingham Engineering, 1979, table 4) showed an average hydraulic conductivity of about 27 feet per day, indicating ground-water flow along a joint or fault.

Effective porosity is defined as the ratio of the volume of interconnected pore space through which water can flow to the total volume of the rock (U.S. Geological Survey, 1989, p. 21). Effective porosity is usually equivalent to actual porosity in unconsolidated deposits, but generally is less than actual porosity in consolidated rocks, where many of the pores may not be connected. Tests by Uygur (1980), the U.S. Geological Survey (unpublished data), and Cordova (1981) on outcrop samples of the Navajo Sandstone and Lamb Point Tongue showed a range in effective porosity from 11 to 30 percent.

Hydraulic gradient is defined as the change in hydraulic head per unit of distance in a given direction (Heath, 1989, p. 10). Generally, the direction is that in which the largest change in head occurs, perpendicular to potentiometric contours. The rate of ground-water movement generally depends on the hydraulic gradient. In the study area, steep hydraulic gradients usually are found in areas of high topographic relief or deeply incised drainages, such as near the East Fork Virgin River in Zion National Park. 
The Darcy velocity equation (Heath, 1989, p. 25) can be used to determine the time of travel for ground water to reach a well as follows:

$$
\mathrm{v}=\frac{\mathrm{Kdh}}{\mathrm{ndl}}
$$

$$
\begin{aligned}
\text { where } \mathrm{K} & =\text { hydraulic conductivity, in feet per day } \\
\mathrm{n} & =\text { effective porosity, in decimal percent } \\
\mathrm{dh} / \mathrm{dl} & =\text { hydraulic gradient, in feet per mile. }
\end{aligned}
$$

Using the minimum values of hydraulic conductivity ( 0.12 foot per day), effective porosity (11 percent), and a hydraulic gradient of 100 feet per mile determined from potentiometric contours in this area, the average linear velocity of ground water in the vicinity of the Kanab City Mace \#2 well, (C-42-6)19bdc-2, in upper Three Lakes Canyon (fig. 6) was determined to be 0.02 foot per day. At this rate, considering only advective flow, time of travel of a contaminant introduced into the aquifer 2 miles upgradient from the well would be about 1,450 years.

If the maximum values of hydraulic conductivity ( 6.1 feet per day) and effective porosity (30 percent) for the same flow path under the same conditions are substituted in equation 1, the average linear velocity is computed to be 0.38 foot per day. At this rate, it would take about 76 years for the contaminant to arrive at the well. These assumptions do not take into account vertical components of ground-water flow, effects of fractures, concentration and characteristics of the contaminant, or the well status during this time. If ground-water flow is substantially enhanced by fractures, travel times would be considerably less. For example, if the hydraulic conductivity of 27 feet per day from the Johnson Canyon aquifer test were substituted for 6.1 feet per day, linear velocity would then be 1.7 feet per day and time of travel could be as small as 17 years. Realistically, time of travel would be between these extreme values, allowing for the lithologic variations present in an anisotropic aquifer such as the Navajo aquifer.

\section{Straight Cliffs Aquifer}

The most vulnerable recharge area for the Straight Cliffs aquifer, in terms of potential for introducing contaminants to the ground water either by accidental spills or by discharge of waste water from industrial and commercial sites, is along U.S. Highway 89 and the East Fork Virgin River north of the community of Glendale (pl. 1). In this area, the highway and river cross outcrops of the Straight Cliffs, Wahweap, and Kaiparowits Formations. Faulting in this area could enhance downward flow of surface water into the Straight Cliffs aquifer.

The potential for ground-water contamination elsewhere over outcrops of the Straight Cliffs, Wahweap, and Kaiparowits Formations is considered minimal at this time (1991) because of the lack of population, commercial or industrial development, and roads. Should a contaminant be introduced to the aquifer, the scarcity of wells and data on aquifer properties precludes any prediction of ground-water-flow directions and the fate of contaminants.

\section{Alluvial Aquifers}

Potential contamination of alluvial aquifers by direct infiltration is possible where alluvial materials fill washes and valleys (pl. 1). Alluvial aquifers in Alton Amphitheater, Sink Valley, 
Skutumpah Creek, Thompson Creek, and Johnson Wash yield water for domestic use and irrigation. These aquifers could be affected by contamination as a result of direct infiltration of waste water from commercial or industrial development. Alluvial aquifers in the upstream part of Johnson Wash where recharge probably takes place, may be susceptible to contamination introduced at land surface where infiltrating precipitation could carry contaminants down into the saturated zone. Streamflow originating from high elevations to the north and entering Johnson Wash could also serve as a mechanism for introducing contaminants into alluvial aquifers (fig. 5).

\section{QUALITY OF WATER IN THE PRINCIPAL AQUIFERS}

Standards for ground-water quality with respect to selected trace metals, inorganic chemicals, organic chemicals (pesticides and volatile organic compounds), and radionuclides from the State of Utah Ground-Water-Quality Protection Regulations (Utah Department of Health, 1989) are shown in table 1. Results of analyses for water from 44 wells and 51 springs including the eight samples collected during the study are presented in tables 2 and 3. Locations of wells and springs from which water has been sampled are shown in figure 7. Analyses for organic compounds were not available for samples collected by the U.S. Geological Survey or the Utah Department of Health ${ }^{1}$ prior to this study (1990). Consequently, results of organic analyses are available only for the eight water samples collected during the study. Inorganic constituents analyzed included calcium, magnesium, sodium, potassium, bicarbonate, sulfate, chloride, fluoride, silica, and nitrate (including nitrite). Of these cations and anions, only fluoride and nitrate are regulated under the State ground-water-quality standards.

\section{Navajo Aquifer}

Analyses for dissolved-solids concentrations in water from the upper Navajo and Lamb Point aquifers are available for 48 sites in the study area (table 2). Eleven of the sites are springs and 37 sites are wells. Concentrations of dissolved-solids in water from the most recent analyses are plotted in figure 7. Most wells sampled are in Three Lakes Canyon and Johnson Wash. Most springs that were sampled are along the lower part of Kanab Creek.

${ }^{1}$ Since 1989, the Utah Department of Health has become a separate branch from the Department of Environmental Quality. 


\section{Table 1.-State of Utah ground-water-quality standards ${ }^{1}$ for protection of drinking water}

(Utah Department of Health, 1989)

Sclected chemical

clement or compound
Maximum allowable concentration

(in micrograms per liter, unless noted otherwise)

Metals

Arsenic $\quad 50$

Barium $\quad 1,000$

Cadmium $\quad 10$

Chromium $\quad 50$

Copper $\quad 1,000$

Lead $\quad 50$

Mcrcury 2

Sclcnium 10

Silver $\quad 50$

Zinc $\quad 5,000$

Inorganic Chemicals

Fluoride

Nitrate (as nitrogen)

2.4 milligrams per liter

10 milligrams per liter

Organic Chemicals (Pesticides)

2,4-D

100

2,4,5-TP (Silvex) 10

Endrin $\quad 0.2$

Lindane 4

Mcthoxychlor 100

Toxaphene 5

Volatile Organic Chemicals

Benzene

Carbon Tetrachloride

Trichlorocthylene $\quad 5$

Vinyl Chloride 2

1,1-Dichlorocthylene $\quad 7$

1,2-Dichlorocthanc 5

1,1,1-Trichlorocthane 200

1,4-Dichlorobenzene $\quad 75$

\section{Radionuclides}

Gross-alpha-particlc activity 15 picocurics per liter

(including radium-226)

Combincd radium-226 and radium-228

5 picocurics per liter

${ }^{1}$ The Drinking Water Division has recently adopted ncw drinking-water-quality standards that are different than the ground-water standards. Consequently, the ground-water standards in this table may be revised. 


\section{Table 2.- Selected properties and chemical constituents in water}

[deg C, degrees Celsius; mg/L, milligrams per liter; $\mu \mathrm{g} / \mathrm{L}$, micrograms per liter;

Well or spring location: Refer to section on data-site numbering system.

Date sampled and analytical lab: U, Utah State Health Laboratory; S, Southern Utah State Laboratory; F, Ford by U.S. Geological Survey Laboratory.

Specific conductance: $\mu \mathrm{S} / \mathrm{cm}$, microsiemens per centimeter at 25 degrees Celsius.

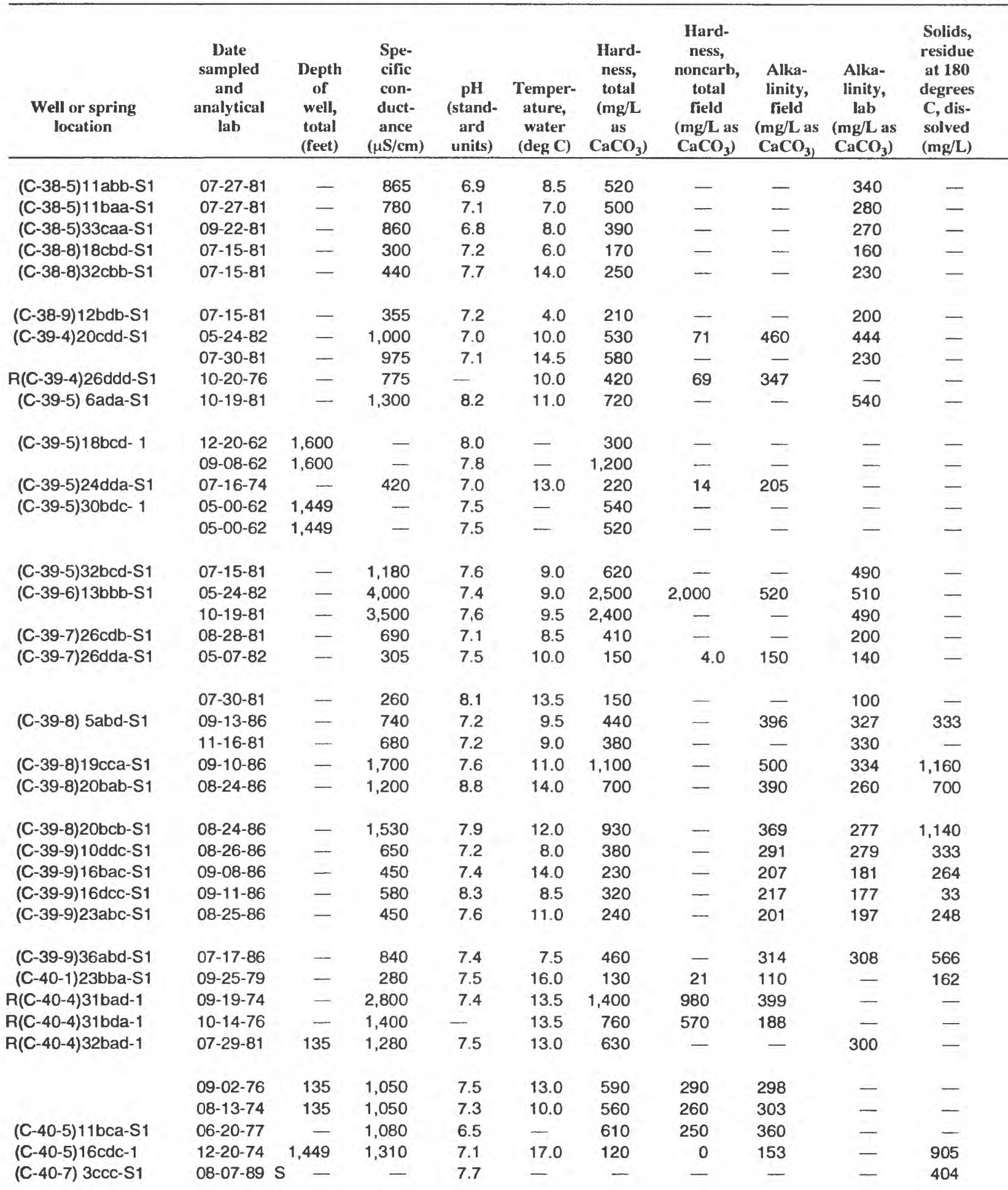




\section{from wells and springs in the study area}

$\mathrm{pCi} / \mathrm{L}$, picocuries per liter; - , no data; <, less than stated value]

Chemical, Salt Lake City; B, BHP-Utah International Minerals Laboratory; all other non-designated analyses

\begin{tabular}{|c|c|c|c|c|c|c|c|c|c|c|}
\hline $\begin{array}{c}\text { Solids, } \\
\text { sum of } \\
\text { consti- } \\
\text { tuents, } \\
\text { dis- } \\
\text { solved } \\
(\mathrm{mg} / \mathrm{L}) \\
\end{array}$ & $\begin{array}{c}\text { Calcium, } \\
\text { dis- } \\
\text { solved, } \\
(\mathrm{mg} / \mathrm{L} \\
\text { as Ca) }\end{array}$ & $\begin{array}{l}\text { Magne- } \\
\text { sium, } \\
\text { dis- } \\
\text { solved } \\
(\mathrm{mg} / \mathrm{L} \\
\text { as } \mathrm{Mg}) \\
\end{array}$ & $\begin{array}{c}\text { Sodium, } \\
\text { dis- } \\
\text { solved } \\
(\mathrm{mg} / \mathrm{L} \\
\text { as } \mathrm{Na}) \\
\end{array}$ & $\begin{array}{l}\text { Potas- } \\
\text { sium, } \\
\text { dis- } \\
\text { solved } \\
\text { (mg/L } \\
\text { as K) } \\
\end{array}$ & $\begin{array}{c}\text { Sulfate, } \\
\text { dis- } \\
\text { solved } \\
(\mathrm{mg} / \mathrm{L} \\
\left.\text { as } \mathrm{SO}_{4}\right) \\
\end{array}$ & $\begin{array}{l}\text { Chlo- } \\
\text { ride, } \\
\text { dis- } \\
\text { solved } \\
\text { (mg/L } \\
\text { as } \mathrm{Cl}) \\
\end{array}$ & $\begin{array}{l}\text { Fluo- } \\
\text { ride, } \\
\text { dis- } \\
\text { solved } \\
\text { (mg/L } \\
\text { as F) } \\
\end{array}$ & $\begin{array}{c}\text { Silica, } \\
\text { dis- } \\
\text { solved } \\
(\mathrm{mg} / \mathrm{L} \\
\text { as } \\
\mathrm{SiO}_{2}\end{array}$ & $\begin{array}{c}\text { Nitro- } \\
\text { gen, } \\
\mathrm{NO}_{2}+\mathrm{NO}_{3} \\
\text { dis- } \\
\text { solved } \\
(\mathrm{mg} / \mathrm{L} \\
\text { as } \mathrm{N}) \\
\end{array}$ & $\begin{array}{c}\text { Gross alpha, } \\
\text { dissolved } \\
(\mathrm{pCi} / \mathrm{L}) \\
\end{array}$ \\
\hline 487 & 100 & 66 & 3.5 & 2.4 & 92 & 3.9 & 0.20 & 15 & 0.06 & - \\
\hline 405 & 110 & 56 & 2.2 & 1.7 & 58 & 2.9 & 0.20 & 10 & 0.12 & - \\
\hline 422 & 44 & 68 & 3.4 & 2.4 & 130 & 3.4 & 0.20 & 8.0 & 0.14 & - \\
\hline 166 & 50 & 10 & 1.4 & 0.40 & $<1$ & 0.70 & 0.10 & 6.0 & 0.08 & - \\
\hline 249 & 60 & 24 & 2.1 & 1.1 & 12 & 1.2 & 0.10 & 10 & 0.02 & - \\
\hline 205 & 63 & 13 & 1.2 & 0.40 & $<1$ & 1.0 & 0.10 & 5.4 & 0.15 & - \\
\hline 599 & 100 & 66 & 14 & 2.7 & 120 & 6.1 & 0.30 & 10 & $<0.10$ & - \\
\hline 474 & 110 & 72 & 1.5 & 3.1 & 13 & 5.7 & 0.20 & 11 & 0.03 & - \\
\hline 519 & 53 & 69 & 26 & 13 & 130 & 9.0 & 0.50 & 9.3 & 0.26 & - \\
\hline 822 & 92 & 120 & 32 & 6.4 & 220 & 11 & 0.30 & 16 & $<0.09$ & - \\
\hline 900 & - & - & - & - & - & - & - & 17 & - & - \\
\hline 3,100 & - & - & - & - & - & - & - & 26 & - & - \\
\hline 238 & 40 & 29 & 1.3 & 1.6 & 33 & 2.5 & 0.20 & 7.4 & 0.09 & - \\
\hline 2,350 & - & - & - & - & - & - & - & 7.0 & - & - \\
\hline 2,390 & - & - & - & - & - & - & - & 8.3 & - & - \\
\hline 773 & 52 & 120 & 46 & 5.3 & 220 & 16 & 0.30 & 18 & 0.38 & - \\
\hline 3,500 & 340 & 400 & 170 & 18 & 2,200 & 33 & 0.50 & 18 & 1.1 & - \\
\hline 3,080 & 360 & 370 & 11 & 15 & 2,000 & 12 & 0.40 & 16 & 1.2 & - \\
\hline 326 & 87 & 48 & 3.0 & 1.6 & 53 & 4.3 & 0.20 & 8.4 & 0.00 & - \\
\hline 175 & 37 & 15 & 1.6 & 1.7 & 19 & 1.2 & 0.70 & 8.8 & $<0.10$ & - \\
\hline 139 & 36 & 14 & 1.4 & 1.7 & 15 & 0.60 & 0.70 & 9.5 & 0.01 & - \\
\hline 438 & 100 & 46 & 2.8 & 1.7 & 37 & 2.8 & 0.20 & 9.5 & 0.13 & - \\
\hline 380 & 87 & 39 & 2.2 & 1.6 & 39 & 2.9 & 0.30 & 9.0 & 0.24 & - \\
\hline 1,250 & 200 & 140 & 25 & 3.5 & 550 & 16 & 0.40 & 16 & $<0.10$ & - \\
\hline 824 & 180 & 62 & 4.6 & 3.0 & 320 & 5.7 & 0.40 & 14 & $<0.10$ & - \\
\hline 1,120 & 190 & 110 & 7.1 & 5.9 & 570 & 6.9 & 0.60 & 9.9 & $<0.10$ & - \\
\hline 396 & 110 & 25 & 2.6 & 1.4 & 70 & 2.7 & 0.20 & 9.0 & $<0.10$ & - \\
\hline 254 & 74 & 11 & 2.5 & 0.90 & 25 & 5.3 & 0.20 & 11 & $<0.10$ & - \\
\hline 352 & 78 & 31 & 3.6 & 2.7 & 94 & 3.9 & 0.20 & 8.0 & $<0.10$ & - \\
\hline 262 & 60 & 23 & 3.6 & 1.6 & 40 & 1.9 & 0.10 & 9.6 & 0.32 & - \\
\hline 536 & 110 & 46 & 5.9 & 2.2 & 170 & 4.6 & 0.20 & 8.2 & 0.10 & - \\
\hline 159 & 32 & 12 & 3.4 & 3.0 & 23 & 5.2 & 0.20 & 12 & 0.18 & - \\
\hline 2,210 & 240 & 190 & 180 & 11 & 1,300 & 34 & 0.60 & 18 & 0.01 & - \\
\hline 1,030 & 90 & 130 & 73 & 8.8 & 590 & 18 & 0.40 & 11 & 0.09 & - \\
\hline 843 & 110 & 84 & 45 & 7.8 & 390 & 11 & 0.50 & 11 & 0.32 & - \\
\hline 785 & 120 & 70 & 38 & 7.4 & 350 & 9.3 & 0.50 & 10 & 0.35 & - \\
\hline 728 & 100 & 75 & 35 & 6.9 & 310 & 8.6 & 0.50 & 9.9 & 0.10 & - \\
\hline 704 & 88 & 95 & 6.0 & 12 & 260 & 14 & 0.20 & 12 & 0.01 & - \\
\hline 808 & 35 & 6.7 & 220 & 8.5 & 430 & 14 & 0.89 & 0.82 & - & - \\
\hline- & - & - & 3.0 & - & 59 & 3.0 & 0.31 & - & 0.16 & - \\
\hline
\end{tabular}


Table 2.-Selected properties and chemical constituents in water

\begin{tabular}{|c|c|c|c|c|c|c|c|c|c|c|c|}
\hline $\begin{array}{c}\text { Well or spring } \\
\text { location }\end{array}$ & $\begin{array}{c}\text { Date } \\
\text { sampled } \\
\text { and } \\
\text { analytical } \\
\text { lab }\end{array}$ & & $\begin{array}{l}\text { Depth } \\
\text { of } \\
\text { well, } \\
\text { total } \\
\text { (feet) }\end{array}$ & $\begin{array}{l}\text { Spe- } \\
\text { cific } \\
\text { con- } \\
\text { duct- } \\
\text { ance } \\
(\mu \mathrm{S} / \mathrm{cm}) \\
\end{array}$ & $\begin{array}{c}\mathrm{pH} \\
\text { (stand- } \\
\text { ard } \\
\text { units) }\end{array}$ & $\begin{array}{c}\text { Temper- } \\
\text { ature, } \\
\text { water } \\
\text { (deg C) }\end{array}$ & $\begin{array}{c}\text { Hard- } \\
\text { ness, } \\
\text { total } \\
(\mathrm{mg} / \mathrm{L} \\
\text { as } \\
\left.\mathrm{CaCO}_{3}\right) \\
\end{array}$ & $\begin{array}{c}\text { Hard- } \\
\text { ness, } \\
\text { noncarb, } \\
\text { total } \\
\text { field } \\
(\mathrm{mg} / \mathrm{L} \text { as } \\
\left.\mathrm{CaCO}_{3}\right) \\
\end{array}$ & $\begin{array}{c}\text { Alka- } \\
\text { linity, } \\
\text { field } \\
(\mathrm{mg} / \mathrm{L} \text { as } \\
\left.\mathrm{CaCO}_{3}\right)\end{array}$ & $\begin{array}{c}\text { Alka- } \\
\text { linity, } \\
\text { lab } \\
(\mathrm{mg} / \mathrm{L} \text { as } \\
\mathrm{CaCO} \text { ) }\end{array}$ & $\begin{array}{l}\text { Solids, } \\
\text { residue } \\
\text { at } 180 \\
\text { degrees } \\
\text { C, dis- } \\
\text { solved } \\
\text { (mg/L) } \\
\end{array}$ \\
\hline (C-40-7)3ccc-S1 & $08-29-81$ & & - & 1,340 & 7.2 & 15.0 & 810 & - & - & 210 & - \\
\hline \multirow[t]{4}{*}{ (C-40-7) 14 bad-1 } & $07-26-85$ & $\mathrm{~S}$ & - & - & 7.4 & - & - & - & - & - & 248 \\
\hline & $02-08-82$ & $U$ & - & 580 & 7.5 & - & 220 & - & - & 328 & 328 \\
\hline & $11-21-77$ & $F$ & - & 468 & 7.8 & - & 176 & - & - & 292 & 303 \\
\hline & $06-22-77$ & & 120 & 540 & 6.5 & 15.5 & 240 & 0 & 300 & - & - \\
\hline \multirow[t]{7}{*}{ (C-40-7)33aad-S1 } & $08-27-86$ & $u$ & - & - & - & - & - & - & - & - & - \\
\hline & $05-27-86$ & $U$ & - & 670 & - & - & 380 & - & - & 270 & 422 \\
\hline & $10-19-82$ & $\mathrm{~S}$ & - & - & 7.9 & - & - & - & - & - & 412 \\
\hline & $10-27-81$ & $U$ & - & - & 一 & - & - & - & - & - & - \\
\hline & $06-30-81$ & U & - & - & - & - & - & - & - & - & - \\
\hline & $05-17-78$ & $\mathbf{F}$ & - & 660 & 7.1 & - & 380 & - & - & 278 & 433 \\
\hline & $11-09-77$ & $\mathrm{~F}$ & - & 630 & 7.3 & - & 370 & - & - & 266 & 404 \\
\hline (C-40-8)7aad-S1 & $07-13-86$ & & - & 560 & 7.9 & 9.0 & 300 & - & 280 & 215 & 262 \\
\hline (C-40-8)7cda-S1 & $07-12-86$ & & - & 460 & 7.7 & 7.5 & 240 & - & 248 & 220 & 211 \\
\hline \multirow[t]{2}{*}{ (C-40-8)29bca-S1 } & $08-19-86$ & & - & 850 & 7.1 & 10.0 & 450 & - & 344 & 269 & 480 \\
\hline & $08-28-81$ & & - & 1,080 & 7.0 & 9.0 & 480 & - & - & 220 & - \\
\hline \multirow{2}{*}{ (C-40-8)30bad-S1 } & $08-20-86$ & & - & 570 & 7.4 & 9.5 & 310 & - & 288 & 209 & 320 \\
\hline & $08-28-81$ & & - & 695 & 7.3 & 9.0 & 310 & - & - & 150 & - \\
\hline \multirow[t]{3}{*}{ (C-40-9) 12daa-S1 } & $07-13-86$ & & - & 610 & 7.4 & 11.5 & 310 & - & 276 & 269 & 347 \\
\hline & $09-09-86$ & & - & 600 & 7.4 & 12.0 & - & - & - & - & - \\
\hline & $08-22-86$ & & - & 600 & - & 11.5 & - & - & - & - & - \\
\hline (C-40-9)13bdc-S1 & $08-22-86$ & & - & 980 & 7.6 & 7.0 & 560 & - & 324 & 227 & 730 \\
\hline (C-40-9)23bcc-S1 & $08-21-86$ & & - & 590 & 7.8 & 8.0 & 300 & - & 280 & 228 & 305 \\
\hline (C-40-9)26bbc-S1 & $08-21-86$ & & - & 350 & 7.7 & 9.0 & 200 & - & 203 & 194 & 216 \\
\hline \multirow[t]{3}{*}{ (C-40-9)26cda-S1 } & $09-14-86$ & & - & 495 & 7.5 & 10.0 & 270 & - & 250 & 205 & 272 \\
\hline & $06-07-82$ & & - & 510 & 7.4 & 10.0 & 270 & 17 & 250 & 226 & - \\
\hline & $08-28-81$ & & - & 475 & 7.3 & 9.0 & 350 & - & - & 150 & - \\
\hline \multirow[t]{3}{*}{ (C-40-9)26cdc-S1 } & $08-21-86$ & & - & 470 & 7.5 & 11.0 & - & - & - & - & - \\
\hline & $06-07-82$ & & - & 530 & 7.6 & 10.5 & 270 & 25 & 250 & 245 & - \\
\hline & $08-28-81$ & & - & 510 & 7.3 & 10.0 & 270 & - & - & 150 & - \\
\hline (C-40-9)27adc-S1 & $07-15-86$ & & - & 450 & 8.0 & 13.0 & 240 & - & 254 & 244 & 242 \\
\hline \multirow[t]{3}{*}{ (C-40-9)35bab-S1 } & $08-21-86$ & & - & 495 & 7.4 & 11.0 & 280 & - & 259 & 224 & 177 \\
\hline & $06-07-82$ & & - & 525 & 7.4 & 11.0 & 280 & 15 & 260 & 248 & - \\
\hline & $08-28-81$ & & - & 520 & 7.3 & 10.0 & 280 & - & - & 190 & - \\
\hline \multirow[t]{4}{*}{$(\mathrm{C}-40-9) 36 \mathrm{ccb}-\mathrm{S} 1$} & $08-20-86$ & & - & 495 & - & 9.0 & - & - & - & - & - \\
\hline & $07-14-86$ & & - & 500 & 7.6 & 9.0 & 260 & - & 260 & 244 & 244 \\
\hline & $08-17-82$ & & - & 425 & 7.9 & 24.5 & 250 & 0 & 260 & 217 & - \\
\hline & $08-28-81$ & & - & 520 & 7.3 & 10.5 & 300 & - & - & 150 & - \\
\hline (C-41-3) 4 bca-1 & $06-12-81$ & & 250 & 415 & 7.6 & 12.5 & 220 & - & - & 150 & - \\
\hline $\mathrm{R}(\mathrm{C}-41-4) 6 \mathrm{adc}-\mathrm{S} 1$ & $10-20-76$ & & - & 1,210 & - & 11.0 & 650 & 350 & 304 & - & - \\
\hline \multirow[t]{3}{*}{$(\mathrm{C}-41-7) 3 \mathrm{cca}-1$} & $08-27-86$ & $u$ & - & - & - & - & - & - & - & - & - \\
\hline & $05-27-86$ & U & - & 395 & - & - & 205 & - & - & 141 & 260 \\
\hline & $12-12-81$ & $F$ & - & 450 & 8.0 & - & 210 & - & - & 197 & 290 \\
\hline \multirow[t]{2}{*}{ (C-41-7)4aaa-1 } & $08-27-86$ & U & - & - & - & - & - & - & - & - & - \\
\hline & $05-27-86$ & U & - & 670 & 7.8 & - & 380 & - & - & 270 & 430 \\
\hline
\end{tabular}




\begin{tabular}{|c|c|c|c|c|c|c|c|c|c|c|}
\hline $\begin{array}{l}\text { Solids, } \\
\text { sum of } \\
\text { consti- } \\
\text { tuents, } \\
\text { dis- } \\
\text { solved } \\
(\mathrm{mg} / \mathrm{L})\end{array}$ & $\begin{array}{c}\text { Calcium, } \\
\text { dis- } \\
\text { solved, } \\
(\mathrm{mg} / \mathrm{L} \\
\text { as Ca) }\end{array}$ & $\begin{array}{c}\text { Magne- } \\
\text { sium, } \\
\text { dis- } \\
\text { solved } \\
\text { (mg/L } \\
\text { as Mg) } \\
\end{array}$ & $\begin{array}{c}\text { Sodium, } \\
\text { dis- } \\
\text { solved } \\
(\mathrm{mg} / \mathrm{L} \\
\text { as } \mathrm{Na}) \\
\end{array}$ & $\begin{array}{l}\text { Potas- } \\
\text { sium, } \\
\text { dis- } \\
\text { solved } \\
(\mathrm{mg} / \mathrm{L} \\
\text { as K) }\end{array}$ & $\begin{array}{l}\text { Sulfate, } \\
\text { dis- } \\
\text { solved } \\
(\mathrm{mg} / \mathrm{L} \\
\left.\text { as } \mathrm{SO}_{4}\right)\end{array}$ & $\begin{array}{l}\text { Chlo- } \\
\text { ride, } \\
\text { dis- } \\
\text { solved } \\
(\mathrm{mg} / \mathrm{L} \\
\text { as } \mathrm{Cl}) \\
\end{array}$ & $\begin{array}{c}\text { Fluo- } \\
\text { ride, } \\
\text { dis- } \\
\text { solved } \\
(\mathbf{m g} / \mathrm{L} \\
\text { as F) } \\
\end{array}$ & 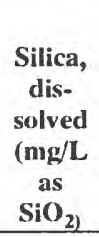 & $\begin{array}{c}\text { Nitro- } \\
\text { gen, } \\
\mathrm{NO}_{2}+\mathrm{NO}_{3} \\
\text { dis- } \\
\text { solved } \\
\text { (mg/L } \\
\text { as } \mathrm{N}) \\
\end{array}$ & $\begin{array}{c}\text { Gross alpha, } \\
\text { dissolved } \\
(\mathrm{pCi} / \mathrm{L})\end{array}$ \\
\hline 739 & 130 & 120 & 1.1 & 8.4 & 330 & 15 & 0.40 & 12 & 0.03 & - \\
\hline- & - & - & 25 & - & 3.0 & 3.0 & 0.11 & - & 0.08 & - \\
\hline- & 53 & 21 & 32 & 8.0 & 6 & 4.0 & 1.0 & 12 & $<0.05$ & 2.0 \\
\hline- & 41 & 18 & 51 & 8.0 & 4.0 & 6.0 & 0.86 & 11 & 0.20 & - \\
\hline 318 & 65 & 20 & 28 & 7.8 & 3.8 & 4.5 & 1.0 & 11 & 0.01 & - \\
\hline- & - & - & - & - & - & - & - & - & - & $<1$ \\
\hline- & 86 & 40 & 5.0 & 4.0 & 120 & 3.0 & 0.70 & 5.0 & 0.02 & 2.5 \\
\hline- & - & - & $<2$ & - & 12 & 6.0 & 0.06 & - & 0.07 & $<5$ \\
\hline- & - & - & - & - & - & - & - & - & - & 1.0 \\
\hline- & - & - & - & - & - & - & - & - & - & 2.0 \\
\hline- & 88 & 38 & 8.0 & 4.0 & 110 & 10 & 0.60 & 12 & 0.31 & - \\
\hline- & 86 & 38 & 4.0 & 4.0 & 110 & 2.0 & 0.65 & 9.0 & 0.20 & - \\
\hline 323 & 74 & 29 & 2.8 & 1.8 & 35 & 2.9 & 0.20 & 9.7 & $<0.10$ & - \\
\hline 263 & 68 & 17 & 1.9 & 2.0 & 16 & 1.7 & 0.20 & 7.3 & $<0.10$ & - \\
\hline 457 & 100 & 49 & 9.3 & 3.3 & 120 & 4.0 & 0.20 & 9.9 & $<0.10$ & - \\
\hline 501 & 110 & 52 & 9.5 & 3.4 & 180 & 5.4 & 0.20 & 10 & 0.03 & $\ldots$ \\
\hline 333 & 83 & 26 & 2.2 & 2.0 & 35 & 2.1 & 0.10 & 8.8 & 0.22 & - \\
\hline 260 & 82 & 26 & 2.3 & 2.1 & 38 & 10 & 0.10 & 9.1 & 0.09 & - \\
\hline 344 & 79 & 28 & 4.6 & 1.6 & 54 & 2.6 & 0.10 & 8.3 & 0.14 & - \\
\hline- & - & - & - & - & - & - & - & - & - & - \\
\hline- & - & - & - & - & - & - & - & - & - & - \\
\hline 628 & 120 & 62 & 3.9 & 2.7 & 230 & 3.6 & 0.20 & 9.8 & 0.26 & - \\
\hline 326 & 75 & 28 & 3.3 & 1.4 & 40 & 2.5 & 0.10 & 8.2 & $<0.10$ & - \\
\hline 212 & 64 & 10 & 1.2 & 0.50 & 4.0 & 1.2 & 0.10 & 7.3 & 0.49 & - \\
\hline 283 & 77 & 19 & 1.9 & 0.90 & 23 & 2.4 & 0.10 & 7.9 & 0.16 & - \\
\hline 282 & 74 & 20 & 1.9 & 1.0 & 24 & 2.0 & 0.20 & 7.9 & 0.14 & - \\
\hline 293 & 93 & 28 & 3.7 & 1.4 & 62 & 3.3 & 0.10 & 11 & 0.03 & - \\
\hline - & - & - & - & - & - & - & - & - & - & - \\
\hline 296 & 72 & 23 & 2.8 & 1.6 & 36 & 2.8 & 0.20 & 7.9 & $<0.10$ & - \\
\hline 239 & 72 & 23 & 3.0 & 1.5 & 38 & 2.6 & 0.10 & 8.3 & 0.03 & - \\
\hline 262 & 82 & 8.7 & 2.1 & 0.30 & 5.0 & 1.3 & 0.10 & 10 & $<0.10$ & - \\
\hline 296 & 74 & 23 & 3.1 & 1.6 & 28 & 2.4 & 0.20 & 8.2 & $<0.10$ & - \\
\hline 298 & 74 & 22 & 2.9 & 1.3 & 31 & 2.9 & 0.20 & 8.0 & $<0.10$ & - \\
\hline 264 & 74 & 23 & 3.2 & 1.7 & 37 & 2.7 & 0.10 & 8.5 & 0.04 & - \\
\hline- & - & - & - & - & - & - & - & - & - & - \\
\hline 275 & 71 & 19 & 1.8 & 0.80 & 16 & 1.5 & 0.10 & 7.9 & 0.16 & - \\
\hline 277 & 61 & 23 & 2.1 & 1.2 & 21 & 2.0 & 0.20 & 11 & $<0.10$ & - \\
\hline 238 & 61 & 24 & 2.1 & 0.90 & 24 & 5.4 & 0.10 & 11 & 0.01 & - \\
\hline 251 & 39 & 29 & 6.4 & 1.8 & 28 & 4.1 & 0.00 & 8.1 & 10 & - \\
\hline 891 & 110 & 92 & 52 & 7.0 & 420 & 12 & 0.50 & 11 & 0.84 & - \\
\hline- & - & - & - & - & - & - & - & - & - & $<1$ \\
\hline- & 46 & 22 & 6.0 & 2.0 & 64 & 7.0 & 0.30 & 12 & 0.83 & - \\
\hline - & 49 & 21 & 22 & 10 & 56 & 7.0 & 0.30 & 9.0 & 0.92 & - \\
\hline- & - & - & - & - & - & - & - & - & - & $<1$ \\
\hline- & 87 & 39 & 5.0 & 7.0 & 125 & 3.0 & 0.73 & 5.0 & 0.03 & - \\
\hline
\end{tabular}




\section{Table 2.-Selected properties and chemical constituents in water}

\begin{tabular}{|c|c|c|c|c|c|c|c|c|c|c|}
\hline $\begin{array}{l}\text { Well or spring } \\
\text { location }\end{array}$ & $\begin{array}{c}\text { Date } \\
\text { sampled } \\
\text { and } \\
\text { analytical } \\
\text { lab }\end{array}$ & $\begin{array}{c}\text { Depth } \\
\text { of } \\
\text { well, } \\
\text { total } \\
\text { (feet) }\end{array}$ & $\begin{array}{c}\text { Spe- } \\
\text { cific } \\
\text { con- } \\
\text { duct- } \\
\text { ance } \\
(\mu \mathrm{S} / \mathrm{cm}) \\
\end{array}$ & $\begin{array}{c}\text { pH } \\
\text { (stand- } \\
\text { ard } \\
\text { units) } \\
\end{array}$ & $\begin{array}{l}\text { Temper- } \\
\text { ature, } \\
\text { water } \\
\text { (deg C) }\end{array}$ & $\begin{array}{c}\text { Hard- } \\
\text { ness, } \\
\text { total } \\
(\mathrm{mg} / \mathrm{L} \\
\text { as } \\
\left.\mathrm{CaCO}_{3}\right) \\
\end{array}$ & $\begin{array}{c}\text { Hard- } \\
\text { ness, } \\
\text { noncarb, } \\
\text { total } \\
\text { field } \\
\text { (mg/L as } \\
\mathrm{CaCO}_{3} \text { ) } \\
\end{array}$ & $\begin{array}{c}\text { Alka- } \\
\text { linity, } \\
\text { field } \\
(\mathrm{mg} / \mathrm{L} \text { as } \\
\left.\mathrm{CaCO}_{3}\right)\end{array}$ & $\begin{array}{c}\text { Alka- } \\
\text { linity, } \\
\text { lab } \\
(\mathrm{mg} / \mathrm{L} \text { as } \\
\left.\mathrm{CaCO}_{3}\right)\end{array}$ & $\begin{array}{l}\text { Solids, } \\
\text { residue } \\
\text { at } 180 \\
\text { degrees } \\
\text { C, dis- } \\
\text { solved } \\
(\mathrm{mg} / \mathrm{L}) \\
\end{array}$ \\
\hline \multirow[t]{4}{*}{$(C-41-7) 4$ aaa-1 } & $10-20-82 s$ & - & 一 & - & - & - & - & - & - & 512 \\
\hline & $06-29-81 L$ & - & - & - & - & - & - & - & - & - \\
\hline & $05-17-78 \mathrm{~F}$ & - & 770 & 7.2 & - & 452 & - & - & 354 & 504 \\
\hline & $06-22-77$ & - & 860 & 6.5 & 11.0 & 500 & 110 & 390 & - & - \\
\hline \multirow[t]{6}{*}{$(C-41-7) 18 d b d-1$} & 03-16-89 L & - & - & - & - & - & - & - & - & - \\
\hline & $12-03-87 s$ & - & - & 7.1 & - & - & - & - & - & 860 \\
\hline & $01-28-85 \mathrm{~L}$ & - & 1,500 & - & - & 890 & - & - & 389 & 1,171 \\
\hline & $11-02-81 \mathrm{u}$ & - & - & - & - & - & - & 一 & - & - \\
\hline & $08-03-81 \mathrm{~L}$ & - & - & - & - & - & - & - & - & - \\
\hline & $03-01-80 s$ & - & - & - & - & - & - & - & - & 930 \\
\hline (C-41-7)30bba-1 & $06-13-90$ & 310 & 1.330 & 6.8 & 11.5 & 690 & - & 398 & 406 & 930 \\
\hline \multirow{3}{*}{$(C-41-9) 15 d c d-1$} & $06-19-90$ & 245 & 730 & 7.3 & 14.5 & 350 & - & 260 & 265 & 422 \\
\hline & $07-12-87$ & 245 & 620 & 7.6 & - & 350 & - & - & 267 & 416 \\
\hline & $11-12-77$ & 245 & 700 & 6.8 & 16.0 & 380 & 110 & 270 & - & - \\
\hline \multirow[t]{2}{*}{$(C-41-9) 20 b d b-1$} & $11-14-90$ & 925 & 395 & 7.1 & 21.0 & 170 & - & 129 & 135 & 223 \\
\hline & $07-06-62$ & 925 & - & - & - & 130 & - & - & 108 & 182 \\
\hline$(C-42-4) 19 a d b-1$ & $09-14-86 \mathrm{E}$ & B 226 & 380 & 7.2 & - & 180 & - & - & 164 & - \\
\hline $\mathrm{R}(\mathrm{C}-42-4) 9 \mathrm{bbc}-1$ & $10-21-76$ & 585 & 320 & - & 13.5 & 150 & 1.0 & 153 & 一 & - \\
\hline$R(C-42-4) 32$ dab-S1 & $10-21-76$ & - & 410 & - & 14.0 & 190 & 33 & 153 & - & - \\
\hline (C-42-5)11bab-1 & $10-07-76$ & 160 & 1,100 & 一 & - & 590 & 430 & 160 & - & - \\
\hline \multirow[t]{2}{*}{$(C-42-5) 11 b d a-1$} & $06-18-77$ & - & 570 & 7.8 & 16.0 & 290 & 140 & 150 & - & - \\
\hline & $07-02-76$ & - & 620 & 7.7 & 15.0 & 310 & 150 & 155 & - & - \\
\hline \multirow[t]{6}{*}{$(C-42-5) 11 b d b-1$} & $07-05-89$ & 160 & 670 & 7.8 & 18.0 & 320 & - & - & 163 & - \\
\hline & $08-09-88$ & 160 & 415 & 7.7 & 13.5 & 190 & - & - & 123 & - \\
\hline & $06-19-87$ & 160 & 730 & 7.4 & 16.0 & 340 & - & - & 171 & - \\
\hline & $07-19-83$ & 160 & 780 & 7.2 & 13.5 & 370 & - & - & 190 & - \\
\hline & $07-30-82$ & 160 & 930 & 7.7 & 13.5 & 460 & - & - & 216 & - \\
\hline & $08-29-77$ & 160 & 580 & 6.5 & 13.5 & 280 & 130 & 150 & - & - \\
\hline$(C-42-5) 15 b d c-1$ & $10-07-76$ & 200 & 880 & - & 12.0 & 480 & 260 & 221 & - & - \\
\hline (C-42-5)22adb-S1 & $10-20-76$ & - & 725 & - & 16.5 & 490 & 280 & 200 & - & - \\
\hline$(C-42-5) 23 b b b-1$ & $10-14-76$ & 183 & - & - & - & 120 & 16 & 106 & - & - \\
\hline$(\mathrm{C}-42-5) 25 \mathrm{ccd}-\mathrm{S} 1$ & $10-28-76$ & - & 400 & - & 13.0 & 190 & 13 & 179 & - & - \\
\hline$(\mathrm{C}-42-5) 26 \mathrm{ccc}-1$ & $10-07-76$ & 226 & 405 & - & - & 200 & 48 & 154 & - & - \\
\hline \multirow[t]{2}{*}{ (C-42-5)26cda-2 } & $06-23-77$ & 380 & 320 & 6.5 & 13.0 & 160 & 17 & 140 & - & - \\
\hline & $10-15-76$ & 80 & 320 & - & 13.0 & 160 & 20 & 137 & - & - \\
\hline \multirow[t]{3}{*}{ (C-42-5)27aaa-1 } & $05-18-77$ & 165 & 300 & 6.5 & 13.0 & 150 & 20 & 130 & - & - \\
\hline & $05-16-77$ & 165 & 310 & 6.5 & 13.0 & 150 & 17 & 130 & - & - \\
\hline & $10-01-76$ & 165 & 300 & - & 13.5 & 160 & 26 & 129 & - & - \\
\hline (C-42-5)27add-1 & $10-07-76$ & 125 & 380 & - & - & 190 & 31 & 157 & - & - \\
\hline (C-42-5) 30 ada- 1 & $09-15-86 \mathrm{~B}$ & B 148 & 295 & 7.4 & - & 86 & - & - & 123 & - \\
\hline$(C-42-5) 34 d b b-1$ & $08-24-77$ & 200 & 500 & - & 18.0 & 200 & 93 & 110 & - & - \\
\hline \multirow[t]{4}{*}{$(C-42-5) 35 b b b-1$} & $06-18-90$ & - & 410 & 7.5 & 13.0 & 200 & - & 160 & 164 & 226 \\
\hline & $06-01-77$ & 220 & 370 & 6.5 & 13.0 & 180 & 36 & 150 & - & \\
\hline & $05-28-77$ & 220 & 365 & 6.5 & 13.0 & 180 & 27 & 160 & - & - \\
\hline & $05-25-77$ & 220 & 340 & 6.5 & 13.0 & 180 & 27 & 160 & - & - \\
\hline
\end{tabular}




\begin{tabular}{|c|c|c|c|c|c|c|c|c|c|c|}
\hline $\begin{array}{c}\text { Solids, } \\
\text { sum of } \\
\text { consti- } \\
\text { tuents, } \\
\text { dis- } \\
\text { solved } \\
\text { (mg/L) } \\
\end{array}$ & $\begin{array}{c}\text { Calcium, } \\
\text { dis- } \\
\text { solved, } \\
\text { (mg/L } \\
\text { as Ca) }\end{array}$ & $\begin{array}{c}\text { Magne- } \\
\text { sium, } \\
\text { dis- } \\
\text { solved } \\
(\mathrm{mg} / \mathrm{L} \\
\text { as Mg) }\end{array}$ & $\begin{array}{c}\text { Sodium, } \\
\text { dis- } \\
\text { solved } \\
(\mathrm{mg} / \mathrm{L} \\
\text { as } \mathrm{Na} \text { ) } \\
\end{array}$ & $\begin{array}{l}\text { Potas- } \\
\text { sium, } \\
\text { dis- } \\
\text { solved } \\
(\mathrm{mg} / \mathrm{L} \\
\text { as K) } \\
\end{array}$ & $\begin{array}{c}\text { Sulfate, } \\
\text { dis- } \\
\text { solved } \\
(\mathrm{mg} / \mathrm{L} \\
\left.\text { as } \mathrm{SO}_{4}\right)\end{array}$ & $\begin{array}{l}\text { Chlo- } \\
\text { ride, } \\
\text { dis- } \\
\text { solved } \\
(\mathrm{mg} / \mathrm{L} \\
\text { as } \mathrm{Cl})\end{array}$ & $\begin{array}{l}\text { Fluo- } \\
\text { ride, } \\
\text { dis- } \\
\text { solved } \\
(\mathrm{mg} / \mathrm{L} \\
\text { as F) } \\
\end{array}$ & $\begin{array}{c}\text { Silica, } \\
\text { dis- } \\
\text { solved } \\
(\mathrm{mg} / \mathrm{L} \\
\text { as } \\
\mathrm{SiO}_{2} \\
\end{array}$ & $\begin{array}{c}\begin{array}{c}\text { Nitro- } \\
\text { gen, }\end{array} \\
\mathrm{NO}_{2}+\mathrm{NO}_{3} \\
\text { dis- } \\
\text { solved } \\
(\mathrm{mg} / \mathrm{L} \\
\text { as } \mathrm{N}) \\
\end{array}$ & $\begin{array}{c}\text { Gross alpha, } \\
\text { dissolved } \\
(\mathrm{pCi} / \mathrm{L})\end{array}$ \\
\hline- & - & - & 0 & - & 124 & 3.0 & 0.60 & - & 0.13 & - \\
\hline- & - & - & - & - & - & - & - & - & - & 3.0 \\
\hline- & 91 & 54 & 15 & 3.0 & 114 & 12 & 0.48 & 13 & 0.65 & - \\
\hline 552 & 110 & 54 & 11 & 4.6 & 120 & 6.2 & 0.50 & 11 & 0.68 & - \\
\hline - & - & - & - & - & - & - & - & - & - & 7.0 \\
\hline- & - & - & 50 & - & 270 & 13 & 0.40 & - & 2.9 & - \\
\hline- & 210 & 91 & 46 & 7.0 & 500 & 13 & 0.40 & 14 & 1.5 & $<2$ \\
\hline- & - & - & - & - & - & - & - & - & - & 4.0 \\
\hline- & - & - & - & - & - & - & - & - & - & 8.0 \\
\hline- & - & - & 38 & - & 310 & 9.0 & 0.40 & - & 0.09 & - \\
\hline 889 & 160 & 71 & 33 & 5.2 & 340 & 19 & 0.60 & 13 & 0.90 & 5.0 \\
\hline 429 & 75 & 40 & 16 & 1.9 & 110 & 13 & 0.70 & 13 & 2.7 & 1.31 \\
\hline 424 & 71 & 42 & 16 & 2.6 & 88 & 11 & 0.50 & 13 & 3.9 & - \\
\hline 460 & 78 & 45 & 15 & 2.0 & 130 & 13 & 0.50 & 14 & - & - \\
\hline 230 & 44 & 15 & 11 & 3.9 & 52 & 11 & 0.20 & 11 & 0.40 & 2.23 \\
\hline 185 & 34 & 12 & 8.4 & 4.5 & 39 & 8.5 & 0.20 & 12 & - & - \\
\hline 280 & 48 & 17 & 6.0 & 1.9 & 8.0 & 8.0 & 0.10 & - & 2.3 & - \\
\hline 191 & 40 & 13 & 7.3 & 2.0 & 11 & 6.4 & 0.20 & 11 & 1.9 & - \\
\hline 218 & 38 & 22 & 7.9 & 2.3 & 20 & 6.6 & 0.20 & 11 & 4.1 & - \\
\hline 832 & 150 & 53 & 42 & 4.2 & 450 & 13 & 0.20 & 15 & 1.9 & - \\
\hline 377 & 71 & 27 & 17 & 2.3 & 140 & 7.6 & 0.20 & 12 & 2.5 & - \\
\hline 405 & 75 & 29 & 16 & 2.2 & 160 & 7.6 & 0.20 & 10 & 2.6 & - \\
\hline 440 & 77 & 31 & 20 & 2.6 & 180 & 7.2 & 0.20 & 11 & 2.9 & - \\
\hline 271 & 48 & 18 & 10 & 4.8 & 87 & 9.4 & 0.20 & 11 & 1.9 & - \\
\hline 501 & 82 & 33 & 33 & 12 & 200 & 14 & 0.20 & 11 & 2.9 & - \\
\hline 526 & 88 & 37 & 25 & 2.9 & 220 & 12 & 0.20 & 12 & 3.3 & - \\
\hline 648 & 110 & 45 & 33 & 3.5 & 290 & 10 & 0.20 & 12 & 3.2 & - \\
\hline 362 & 68 & 27 & 16 & 2.7 & 140 & 7.7 & 0.20 & 12 & - & - \\
\hline 618 & 110 & 49 & 24 & 3.2 & 260 & 8.6 & 0.20 & 11 & 4.5 & - \\
\hline 667 & 120 & 45 & 27 & 6.8 & 330 & 9.3 & 0.30 & 7.9 & 0.12 & - \\
\hline 151 & - & - & - & - & - & - & - & 7.5 & - & - \\
\hline 222 & 42 & 21 & 8.4 & 2.2 & 14 & 8.6 & 0.10 & 14 & 1.1 & - \\
\hline 245 & 48 & 20 & 7.9 & 2.1 & 52 & 6.3 & 0.20 & 9.9 & 1.3 & - \\
\hline 180 & 36 & 16 & 5.0 & 1.6 & 8.9 & 6.4 & 0.10 & 11 & 2.4 & - \\
\hline 182 & 35 & 17 & 4.9 & 1.6 & 11 & 6.1 & 0.20 & 12 & 2.6 & - \\
\hline 175 & 39 & 13 & 4.5 & 1.4 & 16 & 5.7 & 0.10 & 11 & 1.2 & - \\
\hline 172 & 38 & 13 & 4.4 & 1.5 & 13 & 5.7 & 0.10 & 11 & 1.4 & - \\
\hline 180 & 39 & 14 & 5.7 & 1.7 & 19 & 6.9 & 0.10 & 10 & 1.4 & - \\
\hline 215 & 44 & 19 & 7.5 & 1.3 & 29 & 6.4 & 0.20 & 11 & 0.58 & - \\
\hline 245 & 28 & 4.0 & 32 & 0.60 & 21 & 3.5 & 0.20 & - & 1.1 & - \\
\hline 294 & 42 & 23 & 19 & 4.0 & 130 & 7.8 & 0.10 & 3.1 & - & - \\
\hline 234 & 48 & 20 & 8.0 & 1.7 & 40 & 7.4 & 0.40 & 10 & 1.3 & 5.34 \\
\hline 209 & 42 & 19 & 8.0 & 1.8 & 29 & 6.3 & 0.20 & 9.5 & 0.92 & - \\
\hline 212 & 42 & 19 & 7.5 & 1.8 & 28 & 6.2 & 0.20 & 9.5 & 0.97 & - \\
\hline 214 & 42 & 19 & 7.5 & 1.8 & 30 & 6.2 & 0.20 & 9.4 & 0.96 & - \\
\hline
\end{tabular}


Table 2.-Selected properties and chemical constituents in water

\begin{tabular}{|c|c|c|c|c|c|c|c|c|c|c|}
\hline $\begin{array}{l}\text { Well or spring } \\
\text { location }\end{array}$ & $\begin{array}{c}\text { Date } \\
\text { sampled } \\
\text { and } \\
\text { analytical } \\
\text { lab }\end{array}$ & $\begin{array}{c}\begin{array}{c}\text { Depth } \\
\text { of } \\
\text { well, } \\
\text { total } \\
\text { (feet) }\end{array} \\
\end{array}$ & $\begin{array}{c}\text { Spe- } \\
\text { cific } \\
\text { con- } \\
\text { duct- } \\
\text { ance } \\
(\mu \mathrm{S} / \mathrm{cm}) \\
\end{array}$ & $\begin{array}{c}\text { pH } \\
\text { (stand- } \\
\text { ard } \\
\text { units) }\end{array}$ & $\begin{array}{c}\text { Temper- } \\
\text { ature, } \\
\text { water } \\
\text { (deg C) } \\
\end{array}$ & $\begin{array}{c}\text { Hard- } \\
\text { ness, } \\
\text { total } \\
(\mathrm{mg} / \mathrm{L} \\
\text { as } \\
\left.\mathrm{CaCO}_{3}\right) \\
\end{array}$ & $\begin{array}{c}\text { Hard- } \\
\text { ness, } \\
\text { noncarb, } \\
\text { total } \\
\text { field } \\
\left(\mathrm{mg}^{2} / \mathrm{L} \text { as }\right. \\
\left.\mathrm{CaCO}_{3}\right) \\
\end{array}$ & $\begin{array}{c}\text { Alka- } \\
\text { linity, } \\
\text { field } \\
\text { (mg/L as } \\
\mathrm{CaCO}_{3} \text { ) }\end{array}$ & $\begin{array}{c}\text { Alka- } \\
\text { linity, } \\
\text { lab } \\
\left(\mathrm{mg}^{2} \mathrm{~L} \text { as }\right. \\
\left.\mathrm{CaCO}_{3}\right) \\
\end{array}$ & $\begin{array}{c}\text { Solids, } \\
\text { residue } \\
\text { at } 180 \\
\text { degrees } \\
\text { C, dis- } \\
\text { solved } \\
(\mathrm{mg} / \mathrm{L}) \\
\end{array}$ \\
\hline$(C-42-5) 36 b b b-1$ & $04-27-77$ & 220 & 370 & - & 13.0 & 190 & 34 & 156 & - & - \\
\hline (C-42-6)17ddc-S1 & $10-29-76$ & - & - & - & - & 130 & 13 & 118 & - & - \\
\hline (C-42-6)19baa-1 & $08-28-77$ & 560 & 190 & 6.5 & 14.5 & 88 & 6.0 & 82 & - & - \\
\hline \multirow[t]{12}{*}{ (C-42-6) $19 b d c-2$} & $11-15-90$ & J - & 245 & 7.9 & 13.0 & 130 & - & - & 116 & 144 \\
\hline & $06-14-84$ & 250 & 245 & - & 15.0 & - & - & - & - & - \\
\hline & 07-19-83 & 250 & 250 & 7.6 & 19.0 & 130 & - & - & 123 & - \\
\hline & $07-30-82$ & 250 & 235 & - & 15.0 & - & - & - & - & - \\
\hline & $01-26-82$ & J - & - & - & - & - & - & - & - & - \\
\hline & $07-30-81$ & 250 & 245 & - & 15.0 & - & - & - & - & - \\
\hline & $08-21-80$ & 250 & 275 & 8.0 & 14.0 & 120 & 9.0 & 110 & - & - \\
\hline & $08-16-79$ & 250 & 270 & 7.9 & 13.5 & 130 & 21 & 110 & - & - \\
\hline & 04-18-78 F & $=-$ & 235 & 7.2 & - & 140 & - & - & 126 & 151 \\
\hline & $06-01-77$ & 250 & 270 & 6.5 & 13.5 & 140 & 17 & 120 & - & - \\
\hline & $05-29-77$ & 250 & 280 & - & 13.5 & 140 & 19 & 120 & - & - \\
\hline & $05-27-77$ & 250 & 270 & - & 13.5 & 140 & 14 & 120 & - & - \\
\hline (C-42-6)20aaa-1 & $10-29-76$ & - & - & - & - & 200 & 39 & 159 & - & - \\
\hline (C-42-6)29dcb-S1 & $06-16-90$ & - & 370 & 7.6 & 13.0 & 180 & - & 166 & 169 & 191 \\
\hline \multirow[t]{3}{*}{ (C-42-6)30baa-1 } & $06-26-87$ & J & - & - & - & - & - & - & - & - \\
\hline & $07-25-86$ & J - & - & - & - & - & - & - & - & - \\
\hline & $06-06-84 \mathrm{~L}$ & J - & 340 & 7.7 & - & 172 & - & - & 174 & 230 \\
\hline (C-42-6)30ccb-S1 & $10-01-76$ & - & 340 & - & 11.5 & 180 & 14 & 163 & - & - \\
\hline \multirow[t]{2}{*}{ (C-42-6)30cda- 2} & $10-04-77$ & 300 & 480 & 6.5 & 11.5 & 270 & 15 & 250 & - & - \\
\hline & $09-28-76$ & 300 & 460 & - & 12.0 & 130 & 14 & 112 & - & - \\
\hline (C-42-6)30dbb-S1 & $06-02-77$ & - & 320 & - & 12.5 & 200 & 53 & 150 & - & - \\
\hline \multirow[t]{3}{*}{ (C-42-6)30dbc-1 } & $06-26-87 \mathrm{~L}$ & J - & - & - & - & - & - & - & - & - \\
\hline & $08-21-85 s$ & $5-$ & - & - & - & - & - & - & - & 288 \\
\hline & $06-02-77$ & - & 550 & 6.5 & 18.0 & 310 & 16 & 300 & - & - \\
\hline \multirow{6}{*}{$(C-42-6) 31$ dac-1 } & $11-15-90 \mathrm{C}$ & J - & 390 & 7.7 & 13.5 & 170 & - & - & 184 & 224 \\
\hline & $07-29-86 L$ & J - & - & - & - & - & - & - & - & - \\
\hline & $04-01-85 \mathrm{C}$ & J - & 390 & 8.3 & - & 157 & - & - & 185 & 208 \\
\hline & $01-26-82$ u & J - & - & - & - & - & - & - & - & - \\
\hline & $04-29-81 L$ & J - & - & - & - & - & - & - & - & - \\
\hline & $09-28-76$ & 185 & 380 & - & 14.5 & 190 & 5.0 & 186 & - & - \\
\hline (C-42-6)32abd-1 & $10-29-76$ & - & - & - & - & 240 & 66 & 173 & - & - \\
\hline \multirow[t]{3}{*}{ (C-42-6)32bcc-1 } & $06-26-87 u$ & J & 465 & 7.8 & - & 250 & - & - & 241 & 240 \\
\hline & $08-14-85 \mathrm{~L}$ & J - & - & - & - & - & - & - & - & - \\
\hline & $01-23-84 \mathrm{~L}$ & J - & 530 & 7.3 & - & 260 & - & - & 251 & 286 \\
\hline$(\mathrm{C}-42-7) 25 \mathrm{ccc}-\mathrm{S} 1$ & $10-01-76$ & - & 300 & - & 12.5 & 160 & 16 & 144 & - & - \\
\hline (C-43-1)3bac-1 & $02-25-81$ & 302 & 1,520 & 7.1 & 16.5 & 390 & - & - & 120 & - \\
\hline (C-43-5)2bbd-1 & $07-15-77$ & 210 & 690 & 6.5 & 13.5 & 350 & 170 & 180 & - & - \\
\hline (C-43-5)2ddd-S1 & $10-05-76$ & - & 850 & - & 16.0 & 480 & 200 & 281 & - & - \\
\hline$(C-43-5) 8 c c c-1$ & $09-15-86 \quad B$ & 115 & 380 & 7.1 & - & 160 & - & - & 164 & - \\
\hline$(C-43-7) 12 b d b-1$ & $06-14-77$ & 265 & 340 & 6.5 & - & 190 & - & - & 172 & - \\
\hline (C-43-7)16dbb-1 & $06-14-90$ & 159 & 350 & 7.6 & 12.0 & 180 & - & 168 & 173 & 184 \\
\hline (C-43-8) 1 aca-S1 & $05-01-77$ & - & 260 & - & - & 130 & 13 & 115 & - & - \\
\hline (C-43-8)34bab-1 & $04-19-90 u$ & 11,001 & - & 7.9 & - & 84 & - & - & 79 & 102 \\
\hline
\end{tabular}




\begin{tabular}{|c|c|c|c|c|c|c|c|c|c|c|}
\hline $\begin{array}{c}\text { Solids, } \\
\text { sum of } \\
\text { consti- } \\
\text { tuents, } \\
\text { dis- } \\
\text { solved } \\
(\mathrm{mg} / \mathrm{L}) \\
\end{array}$ & $\begin{array}{l}\text { Calcium, } \\
\text { dis- } \\
\text { solved, } \\
\text { (mg/L } \\
\text { as Ca) } \\
\end{array}$ & $\begin{array}{l}\text { Magne- } \\
\text { sium, } \\
\text { dis- } \\
\text { solved } \\
(\mathrm{mg} / \mathrm{L} \\
\text { as } \mathrm{Mg}) \\
\end{array}$ & $\begin{array}{c}\text { Sodium, } \\
\text { dis- } \\
\text { solved } \\
\text { (mg/L } \\
\text { as } \mathbf{N a} \text { ) } \\
\end{array}$ & $\begin{array}{l}\text { Potas- } \\
\text { sium, } \\
\text { dis- } \\
\text { solved } \\
(\mathrm{mg} / \mathrm{L} \\
\text { as K) } \\
\end{array}$ & $\begin{array}{c}\text { Sulfate, } \\
\text { dis- } \\
\text { solved } \\
(\mathrm{mg} / \mathrm{L} \\
\left.\text { as } \mathrm{SO}_{4}\right)\end{array}$ & $\begin{array}{l}\text { Chlo- } \\
\text { ride, } \\
\text { dis- } \\
\text { solved } \\
(\mathrm{mg} / \mathrm{L} \\
\text { as } \mathrm{Cl}) \\
\end{array}$ & $\begin{array}{l}\text { Fluo- } \\
\text { ride, } \\
\text { dis- } \\
\text { solved } \\
(\mathrm{mg} / \mathrm{L} \\
\text { as F) } \\
\end{array}$ & $\begin{array}{c}\begin{array}{c}\text { Silica, } \\
\text { dis- } \\
\text { solved } \\
(\mathrm{mg} / \mathrm{L}\end{array} \\
\text { as } \\
\left.\mathrm{SiO}_{2}\right)\end{array}$ & $\begin{array}{c}\text { Nitro- } \\
\text { gen, } \\
\mathrm{NO}_{2}+\mathrm{NO}_{3} \\
\text { dis- } \\
\text { solved } \\
(\mathrm{mg} / \mathrm{L} \\
\text { as } \mathrm{N}) \\
\end{array}$ & $\begin{array}{c}\text { Gross alpha, } \\
\text { dissolved } \\
(\mathrm{pCi} / \mathrm{L})\end{array}$ \\
\hline 221 & 43 & 20 & 7.8 & 1.7 & 33 & 7.0 & 0.20 & 9.6 & 1.1 & - \\
\hline 154 & 26 & 16 & 4.4 & 2.0 & 6.3 & 3.8 & 0.10 & 15 & 2.1 & - \\
\hline 141 & 19 & 9.9 & 18 & 2.4 & 34 & 8.3 & 0.20 & 0.20 & - & - \\
\hline - & 24 & 17 & 4.0 & 2.0 & 7.0 & 3.5 & 0.07 & 15 & 2.3 & 5.0 \\
\hline- & - & - & - & - & - & - & - & - & - & - \\
\hline 160 & 26 & 17 & 4.1 & 2.4 & 8.0 & 3.8 & $<0.10$ & 14 & 2.5 & - \\
\hline - & - & - & - & - & - & - & - & - & - & - \\
\hline- & - & - & - & - & - & - & - & - & - & $<1$ \\
\hline- & - & - & - & - & - & - & - & - & - & - \\
\hline 148 & 23 & 15 & 3.8 & 2.8 & 5.1 & 4.9 & 0.10 & 14 & 3.0 & - \\
\hline 156 & 26 & 16 & 4.5 & 2.2 & 12 & 4.0 & 0.10 & 14 & 2.6 & - \\
\hline- & 33 & 13 & 6.0 & 2.0 & 20 & 10 & 0.08 & 13 & 2.2 & - \\
\hline 164 & 28 & 17 & 4.0 & 2.3 & 10 & 4.3 & 0.10 & 13 & 2.5 & - \\
\hline 165 & 29 & 17 & 4.0 & 2.4 & 10 & 4.1 & 0.10 & 13 & 2.6 & - \\
\hline 164 & 27 & 17 & 4.0 & 2.4 & 11 & 4.1 & 0.10 & 13 & 2.7 & - \\
\hline 231 & 43 & 22 & 7.7 & 2.5 & 40 & 5.3 & 0.20 & 11 & 0.84 & - \\
\hline 206 & 44 & 18 & 5.1 & 1.5 & 8.8 & 7.2 & 0.20 & 11 & 2.1 & 0.83 \\
\hline- & - & - & - & - & - & - & - & - & - & 6.0 \\
\hline- & - & - & - & - & - & - & - & - & - & 3.0 \\
\hline- & 43 & 16 & 5.0 & 2.0 & 5.0 & 1.0 & 0.06 & 14 & 1.08 & - \\
\hline 194 & 51 & 12 & 3.9 & 1.3 & 5.8 & 4.9 & 0.10 & 8.2 & 2.1 & - \\
\hline 281 & 60 & 29 & 6.8 & 2.8 & 9.0 & 7.9 & 0.10 & 13 & - & - \\
\hline 150 & 24 & 16 & 3.8 & 2.2 & 6.6 & 4.9 & 0.10 & 13 & 2.7 & - \\
\hline 200 & 54 & 16 & 5.0 & 2.5 & 6.1 & 5.5 & 0.10 & 10 & 2.8 & - \\
\hline- & - & - & - & - & - & - & - & - & - & $<1$ \\
\hline- & - & - & - & - & 5.0 & 22 & 0.16 & - & 0.30 & - \\
\hline 329 & 80 & 27 & 9.0 & 2.2 & 5.9 & 6.6 & 0.20 & 18 & 0.62 & - \\
\hline- & 34 & 21 & 8.0 & 2.0 & 11 & 9.0 & 0.10 & 10 & 1.1 & 1.0 \\
\hline- & - & - & - & - & - & - & - & - & - & $<3$ \\
\hline- & 34 & 18 & 7.0 & 2.0 & 11 & 8.0 & 0.10 & 12 & 1.32 & - \\
\hline- & - & - & - & - & - & - & - & - & - & 2.0 \\
\hline- & - & - & - & - & - & - & - & - & - & 1.0 \\
\hline 217 & 47 & 18 & 7.1 & 2.4 & 6.9 & 8.1 & 0.10 & 8.7 & 1.5 & - \\
\hline 283 & 56 & 24 & 8.6 & 2.5 & 69 & 5.7 & 0.30 & 10 & 0.74 & - \\
\hline- & 55 & 28 & 7.0 & 2.0 & 8.0 & 7.0 & 0.10 & 12 & 0.79 & - \\
\hline- & - & - & - & - & - & - & - & - & - & $<2$ \\
\hline- & 64 & 23 & 10 & 2.0 & 15 & 8.0 & 0.50 & 15 & 1.1 & - \\
\hline 175 & 41 & 14 & 2.8 & 1.2 & 5.6 & 3.9 & 0.10 & 8.9 & 2.4 & - \\
\hline 1,040 & 91 & 38 & 190 & 7.1 & 590 & 33 & 1.0 & 9.2 & 0.09 & - \\
\hline 456 & 77 & 38 & 20 & 2.8 & 170 & 8.1 & 0.10 & 11 & 4.7 & - \\
\hline 667 & 87 & 65 & 39 & 9.1 & 250 & 21 & 0.30 & 24 & 0.43 & - \\
\hline 290 & 47 & 11 & 10 & 0.80 & 6.0 & 6.4 & 0.17 & - & 1.5 & - \\
\hline 204 & 53 & 15 & 5.9 & 0.90 & 5.9 & 7.0 & 0.20 & 13 & - & - \\
\hline 197 & 51 & 13 & 3.2 & 2.6 & 5.3 & 4.9 & 0.30 & 11 & 1.0 & 1.31 \\
\hline 161 & 41 & 6.2 & 5.1 & 0.50 & 13 & 4.3 & 0.10 & 19 & 0.54 & - \\
\hline- & - & 9.0 & 2.0 & 3.0 & $<5$ & 3.4 & 0.07 & 14.5 & 0.89 & - \\
\hline
\end{tabular}




\section{Table 3.-Selected trace element concentrations in water from wells and springs in the study area}

$[\mu \mathrm{g} / \mathrm{L}$, micrograms per litcr; - , no data; <, less than stated valuc]

Well or spring location : Refer to section on data-sitc numbering system.

Datc sampled and analytical lab: U, Utah Statc Health Laboratory; S, Southern Utah Statc Laboratory; F, Ford Chemical, Salt Lake City; B, BHP-Utah International Mincrals Laboratory; all other non-designatcd analyses by U.S. Gcological Survey Laboratory. Concentrations for analyses designated by U, S, F are total (dissolved and suspended) except where indicated by (D), dissolved only.

\begin{tabular}{|c|c|c|c|c|c|c|c|c|c|c|c|c|c|}
\hline $\begin{array}{l}\text { Well or spring } \\
\text { location }\end{array}$ & $\begin{array}{c}\text { Date } \\
\text { sampled } \\
\text { and } \\
\text { analylical } \\
\text { lab }\end{array}$ & $\begin{array}{c}\text { Arsenic, } \\
\text { dis- } \\
\text { solved } \\
\text { ( } \mu \mathrm{g} / \mathrm{L} \\
\text { as As) }\end{array}$ & $\begin{array}{c}\text { Barium, } \\
\text { dis- } \\
\text { solved } \\
\text { ( } \mu \mathrm{g} / \mathrm{L} \\
\text { as } \mathrm{Ba})\end{array}$ & $\begin{array}{c}\text { Cadmium, } \\
\text { dis- } \\
\text { solved } \\
(\mu \mathrm{g} / \mathrm{L} \\
\text { as Cd) }\end{array}$ & $\begin{array}{l}\text { Chro- } \\
\text { mium, } \\
\text { dis- } \\
\text { solved } \\
(\mu \mathrm{g} / \mathrm{L} \\
\text { as } \mathrm{Cr})\end{array}$ & $\begin{array}{c}\text { Copper, } \\
\text { dis- } \\
\text { solved } \\
(\mu \mathrm{g} / \mathrm{L} \\
\text { as Cu) }\end{array}$ & $\begin{array}{l}\text { Iron, } \\
\text { dis- } \\
\text { solved } \\
(\mu \mathrm{g} / \mathrm{L} \\
\text { as Fe) }\end{array}$ & $\begin{array}{l}\text { Lead, } \\
\text { dis- } \\
\text { solved } \\
(\mu \mathrm{g} / \mathrm{L} \\
\text { as } \mathrm{Pb})\end{array}$ & $\begin{array}{c}\text { Manga- } \\
\text { nese, } \\
\text { dis- } \\
\text { solved } \\
(\mu \mathrm{g} / \mathrm{L} \\
\text { as Mn) }\end{array}$ & $\begin{array}{c}\text { Mercury, } \\
\text { dis- } \\
\text { solved } \\
(\mu \mathrm{g} / \mathrm{L} \\
\text { as Hg) }\end{array}$ & $\begin{array}{c}\text { Scle- } \\
\text { nium, } \\
\text { dis- } \\
\text { solved } \\
(\mu \mathrm{g} / \mathrm{L} \\
\text { as Se) }\end{array}$ & $\begin{array}{c}\begin{array}{c}\text { Silver, } \\
\text { dis- }\end{array} \\
\text { solved } \\
(\mu \mathrm{g} / \mathrm{L} \\
\text { as } \mathrm{Ag})\end{array}$ & $\begin{array}{c}\text { Zinc, } \\
\text { dis- } \\
\text { solved } \\
(\mu \mathrm{g} / \mathrm{L} \\
\text { as } \mathrm{Zn})\end{array}$ \\
\hline (C-38-5) $11 a b b-S 1$ & $07-27-81$ & - & - & - & - & - & 29 & - & 15 & - & - & - & - \\
\hline (C-38-5) 11 baa-S1 & $07-27-81$ & - & - & - & - & - & $<10$ & - & $<1$ & - & 一 & - & - \\
\hline (C-38-5)33caa-S1 & $09-22-81$ & - & - & - & - & - & $<10$ & - & $<1$ & - & - & - & - \\
\hline (C-38-8) $18 \mathrm{cbd}-\mathrm{S} 1$ & $07-15-81$ & - & - & - & - & - & 20 & - & 2 & - & - & - & - \\
\hline (C-38-8)32cbb-S1 & $07-15-81$ & - & - & - & - & - & 20 & - & 6 & - & - & - & 一 \\
\hline (C-38-9)12bdb-S1 & $07-15-81$ & - & - & $\ldots$ & - & - & 20 & - & 2 & - & - & - & - \\
\hline \multirow[t]{2}{*}{ (C-39-4)20cdd-S1 } & $05-24-82$ & - & - & - & - & - & $<9$ & - & $<3$ & - & - & - & - \\
\hline & $07-30-81$ & - & - & - & - & - & $<10$ & - & 2 & - & - & - & - \\
\hline$R(C-39-4) 26 d d d-S 1$ & $10-20-76$ & - & - & - & - & - & - & - & - & - & - & - & - \\
\hline (C-39-5) 6ada-S1 & $10-19-81$ & - & - & - & - & - & $<10$ & - & 100 & - & - & - & - \\
\hline \multirow[t]{2}{*}{ (C-39-5)18bcd- 1} & $12-20-62$ & - & - & - & - & - & - & - & - & - & - & - & - \\
\hline & $09-08-62$ & - & - & - & - & - & - & - & - & - & - & - & - \\
\hline (C-39-5)24dda-S1 & $07-16-74$ & - & - & - & - & - & - & - & - & - & - & - & - \\
\hline \multirow[t]{2}{*}{ (C-39-5)30bdc- 1} & $05-00-62$ & - & - & - & - & - & - & - & - & - & - & - & - \\
\hline & $05-00-62$ & - & - & - & - & - & - & - & - & - & - & - & - \\
\hline (C-39-5)32bcd-S1 & $07-15-81$ & - & - & - & - & - & $<10$ & 一 & 1 & - & - & - & - \\
\hline \multirow[t]{2}{*}{ (C-39-6) $13 \mathrm{bbb}-\mathrm{S} 1$} & $05-24-82$ & - & - & - & - & - & 70 & - & 30 & - & - & - & - \\
\hline & $10-19-81$ & - & 一 & - & - & - & 60 & - & 20 & - & - & - & - \\
\hline (C-39-7)26cdb-S1 & $08-28-81$ & - & - & - & - & - & 720 & - & 140 & - & - & - & - \\
\hline \multirow[t]{2}{*}{ (C-39-7)26dda-S1 } & $05-07-82$ & - & - & - & - & - & 10 & - & 10 & - & - & - & - \\
\hline & $07-30-81$ & - & - & - & - & - & 17 & - & 13 & - & - & - & - \\
\hline \multirow[t]{2}{*}{ (C-39-8) 5abd-S1 } & $09-13-86$ & - & - & - & - & - & 10 & - & 4 & 一 & - & - & 一 \\
\hline & $11-16-81$ & - & - & - & - & - & $<10$ & - & 5 & - & - & - & - \\
\hline (C-39-8)19cca-S1 & $09-10-86$ & - & - & - & - & - & 22 & - & 36 & - & - & - & 一 \\
\hline (C-39-8)20bab-S1 & $08-24-86$ & - & - & - & - & - & 8 & - & 580 & - & - & $一$ & - \\
\hline (C-39-8)20bcb-S1 & $08-24-86$ & - & - & - & - & - & 7 & - & 120 & - & - & - & - \\
\hline (C-39-9)10ddc-S1 & $08-26-86$ & - & - & - & - & - & 560 & - & 55 & - & - & - & - \\
\hline (C-39-9) 16 bac-S1 & $09-08-86$ & - & - & - & - & - & 30 & - & 4 & - & - & - & - \\
\hline (C-39-9) 16 dcc-S1 & $09-11-86$ & - & - & - & - & - & 5 & - & $<1$ & - & - & - & - \\
\hline (C-39-9)23abc-S1 & $08-25-86$ & - & - & - & - & - & $<3$ & - & $<1$ & - & - & - & - \\
\hline (C-39-9)36abd-S1 & $07-17-86$ & - & - & - & - & - & 8 & - & $<1$ & - & - & — & - \\
\hline (C-40-1)23bba-S1 & $09-25-79$ & - & 140 & 3 & - & $<20$ & $<10$ & $<10$ & 1 & - & - & - & 12 \\
\hline$R(C-40-4) 31$ bad-1 & $09-19-74$ & - & - & - & - & - & - & - & - & - & - & - & - \\
\hline$R(C-40-4) 31 b d a-1$ & $10-14-76$ & - & 一 & - & - & - & - & - & - & - & - & - & - \\
\hline$R(C-40-4) 32$ bad- 1 & $07-29-81$ & - & - & - & - & - & 150 & - & 43 & - & - & - & - \\
\hline
\end{tabular}




\section{Table 3.- Selected trace element concentrations in water from wells and springs in the study area-Continued}

\begin{tabular}{|c|c|c|c|c|c|c|c|c|c|c|c|c|c|}
\hline $\begin{array}{c}\text { Well or spring } \\
\text { location }\end{array}$ & $\begin{array}{c}\text { Date Ar } \\
\text { sampled } \\
\text { and } \\
\text { analytical } \\
\text { lab }\end{array}$ & $\begin{array}{l}\text { Arsenic, } \\
\text { dis- } \\
\text { solved } \\
\text { ( } \mu \mathrm{g} / \mathrm{L} \\
\text { as As) }\end{array}$ & $\begin{array}{l}\text { Barium, } \\
\text { dis- } \\
\text { solved } \\
(\mu \mathrm{g} / \mathrm{L} \\
\text { as } \mathrm{Ba})\end{array}$ & $\begin{array}{c}\text { Cadmium, } \\
\text { dis- } \\
\text { solved } \\
(\mu \mathrm{g} / \mathrm{L} \\
\text { as Cd) }\end{array}$ & $\begin{array}{l}\text { Chro- } \\
\text { mium, } \\
\text { dis- } \\
\text { solved } \\
(\mu \mathrm{g} / \mathrm{L} \\
\text { as Cr) }\end{array}$ & $\begin{array}{l}\text { Copper, } \\
\text { dis- } \\
\text { solved } \\
(\mu \mathrm{g} / \mathrm{L} \\
\text { as } \mathrm{Cu})\end{array}$ & $\begin{array}{l}\text { Iron, I } \\
\text { dis- } \\
\text { solved s } \\
(\mu \mathrm{g} / \mathrm{L} \quad( \\
\text { as Fe) a }\end{array}$ & $\begin{array}{l}\text { Lead, } \\
\text { dis- } \\
\text { solved } \\
(\mu \mathrm{g} / \mathrm{L} \\
\text { as } \mathrm{Pb})\end{array}$ & $\begin{array}{l}\text { Manga- } \\
\text { nese, } \\
\text { dis- } \\
\text { solved } \\
(\mu \mathrm{g} / \mathrm{L} \\
\text { as Mn })\end{array}$ & $\begin{array}{c}\text { Mercury, } \\
\text { dis- } \\
\text { solved } \\
(\mu \mathrm{g} / \mathrm{L} \\
\text { as } \mathrm{Hg})\end{array}$ & $\begin{array}{l}\text { Sele- } \\
\text { nium, } \\
\text { dis- } \\
\text { solved } \\
(\mu \mathrm{g} / \mathrm{L} \\
\text { as Sc) }\end{array}$ & $\begin{array}{l}\text { Silver, } \\
\text { dis- } \\
\text { solved } \\
(\mu \mathrm{g} / \mathrm{L} \\
\text { as Ag) }\end{array}$ & $\begin{array}{l}\text { Zinc, } \\
\text { dis- } \\
\text { solved } \\
(\mu \mathrm{g} / \mathrm{L} \\
\text { as } \mathrm{Zn}) \\
\end{array}$ \\
\hline \multirow[t]{2}{*}{$R(C-40-4) 32 b a d-1$} & $09-02-76$ & - & - & - & - & - & - & - & - & - & - & - & - \\
\hline & $08-13-74$ & - & - & - & - & - & - & - & - & - & - & - & - \\
\hline (C-40-5)11 bca-S1 & $06-20-77$ & - & - & - & - & - & 120 & - & 60 & - & - & - & - \\
\hline$(C-40-5) 16 c d c-1$ & $12-20-74$ & 0 & 0 & 0 & 0 & 0 & 6 & 0 & 0 & 0 & 0 & 0 & 0 \\
\hline \multirow{2}{*}{$(C-40-7) 3 c c c-51$} & $08-07-89 \mathrm{~S}$ & 8 & $<100$ & $<2$ & $<10$ & $<10$ & $<50$ & $<10$ & $<5$ & $<1$ & $<5$ & $<5$ & $<50$ \\
\hline & $08-29-81$ & - & - & - & - & - & 16 & - & 140 & - & - & - & - \\
\hline \multirow[t]{4}{*}{ (C-40-7)14bad-1 } & $07-26-85 \mathrm{~S}$ & $<1$ & 160 & $<2$ & $<10$ & 24 & 80 & $<10$ & 29 & $<1$ & $<5$ & 6 & $<50$ \\
\hline & $02-08-82 U$ & $<1$ & 910 & $<1$ & $<5$ & $<10$ & 840 & $<5$ & 35 & 0.1 & $<1$ & $<2$ & $<5$ \\
\hline & $11-21-77 \mathrm{~F}$ & - & $166 \mathrm{D}$ & $D$ - & - & $23 \mathrm{D}$ & $182 \mathrm{D}$ & - & $27 \mathrm{D}$ & - & - & - & $6 \mathrm{D}$ \\
\hline & $06-22-77$ & - & - & - & - & - & 80 & - & 50 & - & - & - & - \\
\hline \multirow[t]{7}{*}{ (C-40-7)33aad-S1 } & $08-27-86 U$ & - & - & - & - & - & - & - & - & - & - & - & - \\
\hline & $05-27-86 \cup$ & 2.5 & $<50$ & $<1$ & $<5$ & $<20$ & 590 & $<5$ & 45 & $<0.1$ & $<0.5$ & $<2$ & 45 \\
\hline & $10-19-82 \mathrm{~S}$ & $<5$ & $<20$ & $<3$ & $<10$ & $<5$ & 20 & 35 & 17 & $<1$ & $<4$ & $<2$ & 10 \\
\hline & $10-27-81 U$ & - & - & - & - & - & - & - & - & - & - & - & - \\
\hline & $06-30-81 \mathrm{U}$ & - & - & - & - & - & - & - & - & - & - & - & - \\
\hline & $05-17-78 \mathrm{~F}$ & $<1 D$ & $130 \mathrm{D}$ & $D<1 D$ & $<1 D$ & $<1 \mathrm{D}$ & $<50 \mathrm{D}$ & $<1 D$ & $55 \mathrm{D}$ & $<0.2$ & $<1 D$ & $\angle 1 D$ & 35 \\
\hline & $11-09-77 \mathrm{~F}$ & 0 & $26 \mathrm{D}$ & D 0 & 0 & $2 D$ & $52 \mathrm{D}$ & 0 & $13 \mathrm{D}$ & 0 & 0 & 0 & 3 \\
\hline (C-40-8) 7aad-S1 & $07-13-86$ & - & - & - & - & - & 5 & - & 6 & - & - & - & - \\
\hline (C-40-8) 7cda-S1 & $07-12-86$ & - & - & - & - & - & 6 & - & $<1$ & - & - & - & - \\
\hline \multirow[t]{2}{*}{ (C-40-8)29bca-S1 } & $08-19-86$ & - & - & - & - & - & 9 & - & $<1$ & - & - & - & - \\
\hline & $08-28-81$ & - & - & - & - & - & $<10$ & - & 1 & - & - & - & - \\
\hline \multirow[t]{2}{*}{ (C-40-8)30bad-S1 } & $08-20-86$ & - & - & - & - & - & 6 & - & 1 & - & - & - & - \\
\hline & $08-28-81$ & - & - & - & - & - & $<10$ & - & 2 & - & - & - & - \\
\hline \multirow[t]{3}{*}{ (C-40-9)12daa-S1 } & $07-13-86$ & - & - & - & - & - & 6 & - & $<1$ & - & - & - & - \\
\hline & $09-09-86$ & - & - & - & - & - & - & - & - & - & - & - & - \\
\hline & $08-22-86$ & - & - & - & - & - & - & - & - & - & - & - & - \\
\hline (C-40-9)13bdc-S1 & $08-22-86$ & - & - & - & - & - & 5 & - & 5 & - & - & - & - \\
\hline (C-40-9)23bcc-S1 & $08-21-86$ & - & - & - & - & - & 8 & - & 2 & - & - & - & - \\
\hline (C-40-9) $26 b b c-S 1$ & $08-21-86$ & - & - & - & - & 一 & 6 & - & $<1$ & - & - & - & - \\
\hline \multirow[t]{3}{*}{ (C-40-9)26cda-S1 } & $09-14-86$ & - & - & - & - & - & $<3$ & - & $<1$ & - & - & - & - \\
\hline & $06-07-82$ & - & - & - & - & - & $<3$ & - & $<1$ & - & - & - & - \\
\hline & $08-28-81$ & - & - & - & - & - & $<10$ & - & $<1$ & - & - & - & - \\
\hline \multirow[t]{3}{*}{$(C-40-9) 26 c d c-S 1$} & $08-21-86$ & - & - & - & - & - & - & - & - & - & - & - & - \\
\hline & $06-07-82$ & - & - & - & - & - & $<3$ & - & $<1$ & - & - & - & - \\
\hline & $08-28-81$ & - & - & - & - & - & $<10$ & - & 1 & - & - & - & - \\
\hline (C-40-9)27adc-S1 & $07-15-86$ & - & - & - & - & - & 14 & - & 29 & - & - & - & - \\
\hline \multirow[t]{3}{*}{ (C-40-9)35bab-S1 } & $08-21-86$ & - & - & - & - & - & $<3$ & - & $<1$ & - & - & - & - \\
\hline & $06-07-82$ & - & - & - & - & - & $<3$ & - & $<1$ & - & - & - & - \\
\hline & $08-28-81$ & - & - & - & - & - & $<10$ & - & $<1$ & - & - & - & - \\
\hline$(C-40-9) 36 \mathrm{ccb}-\mathrm{S} 1$ & $08-20-86$ & - & 一 & - & - & - & - & - & - & - & - & - & - \\
\hline \multirow[t]{3}{*}{ (C-40-9)36ccb-S1 } & $07-14-86$ & - & - & - & - & - & 9 & - & $<1$ & - & - & - & - \\
\hline & $08-17-82$ & - & - & - & - & - & 9 & - & 5 & - & - & - & - \\
\hline & $08-28-81$ & - & - & - & - & - & $<10$ & - & 1 & - & - & - & - \\
\hline (C-41-3)4bca-1 & $06-12-81$ & 0 & 500 & - & - & - & 30 & - & - & - & 0 & - & - \\
\hline$R(C-41-4) 6$ adc-S1 & $10-20-76$ & - & - & - & - & - & - & - & - & - & - & - & - \\
\hline
\end{tabular}




\section{Table 3.-Selected trace element concentrations in water from wells and springs in the study area-Continued}

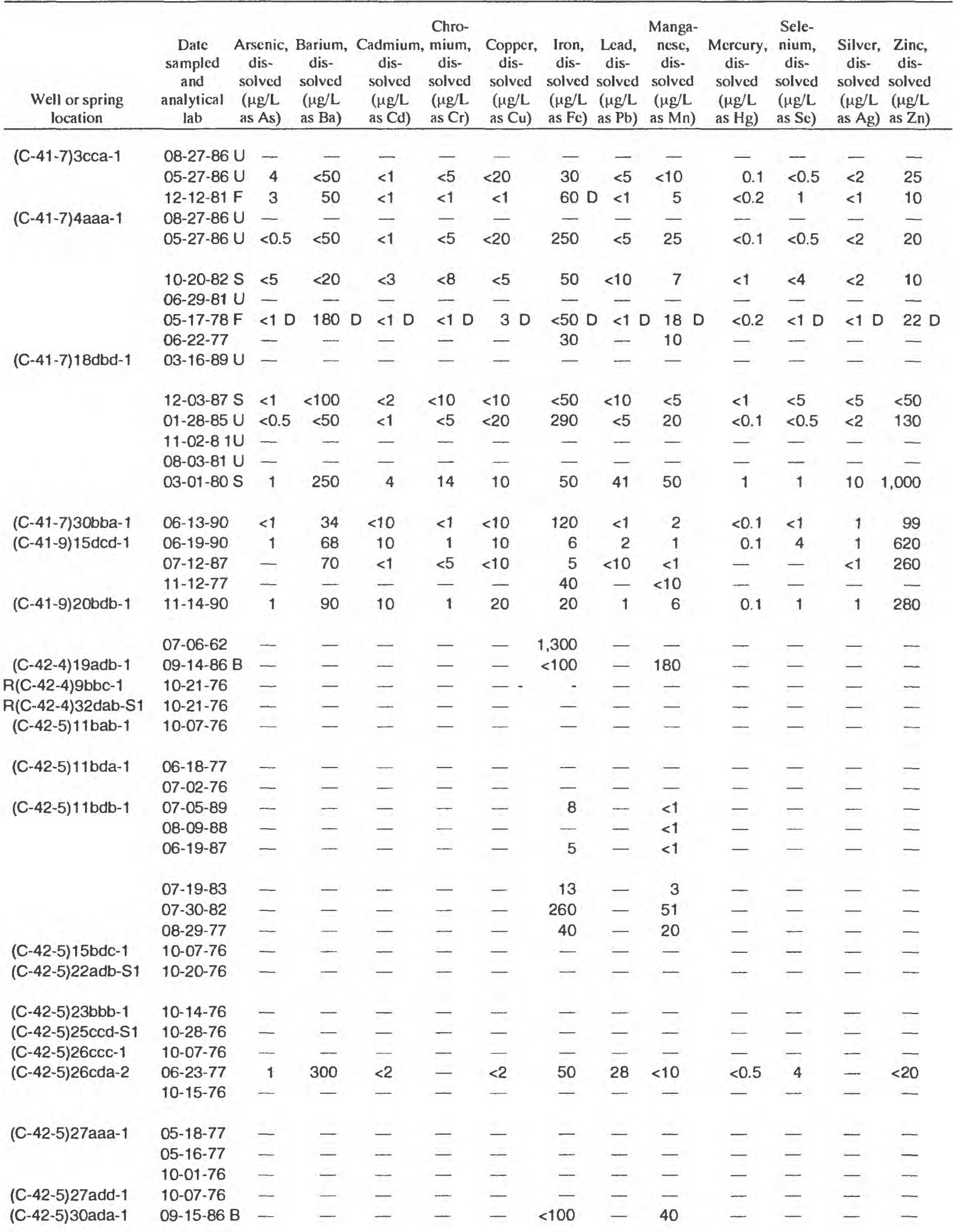




\section{Table 3.- Selected trace element concentrations in water from wells and springs in the study area-Continued}

\begin{tabular}{|c|c|c|c|c|c|c|c|c|c|c|c|c|c|}
\hline $\begin{array}{c}\text { Well or spring } \\
\text { location }\end{array}$ & $\begin{array}{c}\text { Datc Ar } \\
\text { sampled } \\
\text { and } \\
\text { analytical } \\
\text { lab }\end{array}$ & $\begin{array}{l}\text { Arsenic, } \\
\text { dis- } \\
\text { solved } \\
\text { ( } \mu \mathrm{g} / \mathrm{L} \\
\text { as As) }\end{array}$ & $\begin{array}{l}\text { Barium, } \\
\text { dis- } \\
\text { solved } \\
(\mu \mathrm{g} / \mathrm{L} \\
\text { as } \mathrm{Ba})\end{array}$ & $\begin{array}{c}\text { Cadmium, } \\
\text { dis- } \\
\text { solved } \\
(\mu g / L \\
\text { as Cd) }\end{array}$ & $\begin{array}{l}\text { Chro- } \\
\text { mium, } \\
\text { dis- } \\
\text { solved } \\
(\mu \mathrm{g} / \mathrm{L} \\
\text { as Cr) } \\
\end{array}$ & $\begin{array}{c}\text { Copper, } \\
\text { dis- } \\
\text { solved } \\
(\mu \mathrm{g} / \mathrm{L} \\
\text { as } \mathrm{Cu})\end{array}$ & $\begin{array}{l}\text { Iron, L } \\
\text { dis- } \\
\text { solved sc } \\
(\mu \mathrm{g} / \mathrm{L} \quad( \\
\text { as Fe) a }\end{array}$ & $\begin{array}{l}\text { Lead, } \\
\text { dis- } \\
\text { solved } \\
(\mu \mathrm{g} / \mathrm{L} \\
\text { as } \mathrm{Pb})\end{array}$ & $\begin{array}{l}\text { Manga- } \\
\text { nese, } \\
\text { dis- } \\
\text { solved } \\
(\mu \mathrm{g} / \mathrm{L} \\
\text { as } \mathrm{Mn}) \\
\end{array}$ & $\begin{array}{c}\text { Mcrcury, } \\
\text { dis- } \\
\text { solved s } \\
(\mu \mathrm{g} / \mathrm{L} \\
\text { as } \mathrm{Hg})\end{array}$ & $\begin{array}{l}\text { Sele- } \\
\text { nium, } \\
\text { dis- } \\
\text { solved } \\
(\mu \mathrm{g} / \mathrm{L} \\
\text { as Se) }\end{array}$ & $\begin{array}{c}\text { Silver, } \\
\text { dis- } \\
\text { solved } \\
(\mu \mathrm{g} / \mathrm{L} \\
\text { as Ag) } \\
\end{array}$ & $\begin{array}{l}\text { Zinc, } \\
\text { dis- } \\
\text { solved } \\
(\mu \mathrm{g} / \mathrm{L} \\
\text { as } \mathrm{Zn}) \\
\end{array}$ \\
\hline$(C-42-5) 34 d b b-1$ & $08-24-77$ & - & - & - & - & - & 430 & - & 180 & 一 & - & - & - \\
\hline \multirow[t]{5}{*}{$(C-42-5) 35 b b b-1$} & $06-18-90$ & 1 & 150 & 10 & 1 & 10 & 4 & 1 & 6 & 0.1 & 2 & 1 & 6 \\
\hline & $06-01-77$ & $<1$ & $<100$ & $<2$ & - & 2 & 20 & 7 & 40 & $<0.5$ & 1 & - & $<20$ \\
\hline & $05-28-77$ & - & - & - & - & - & $<10$ & - & 20 & 一 & - & - & 一 \\
\hline & $05-25-77$ & - & - & - & - & - & 20 & - & 30 & - & - & - & - \\
\hline & $04-27-77$ & - & - & - & - & - & - & - & - & - & - & - & - \\
\hline (C-42-6)17ddc-S1 & $10-29-76$ & - & - & - & - & - & - & - & - & - & - & - & - \\
\hline (C-42-6)19baa-1 & $08-28-77$ & - & - & - & - & - & 130 & - & $<10$ & - & - & - & - \\
\hline \multirow[t]{12}{*}{$(C-42-6) 19 b d c-2$} & $11-15-90 \mathrm{U}$ & J $<5 \mathrm{D}$ & 63 & $D<1 D$ & $<5 \mathrm{D}$ & $<20 \mathrm{D}$ & $<20 \mathrm{D}$ & $<5 D$ & $D<5 \quad D$ & $<0.2$ & $<1 D$ & $<2 D$ & $<20 \mathrm{D}$ \\
\hline & $06-14-84$ & - & - & - & - & - & - & - & - & - & - & - & - \\
\hline & $07-19-83$ & - & - & - & - & - & 4 & - & 1 & - & - & - & - \\
\hline & $07-30-82$ & - & - & - & - & - & - & - & - & - & - & - & - \\
\hline & $01-26-82 U$ & J - & - & - & - & - & - & - & - & - & - & - & - \\
\hline & $07-30-81$ & - & - & - & - & - & - & - & - & - & - & - & - \\
\hline & $08-21-80$ & - & - & - & - & - & 10 & - & 3 & - & - & - & - \\
\hline & $08-16-79$ & - & - & - & - & - & - & - & - & - & - & - & - \\
\hline & 04-18-78 F & $3 \mathrm{D}$ & $60 \mathrm{~L}$ & $D<1 D$ & $\angle 1 D$ & $3 \mathrm{D}$ & $<50 \mathrm{D}$ & $<1 \mathrm{D}$ & $8 \mathrm{D}$ & $<0.2$ & $4 \mathrm{D}$ & $<1 D$ & $25 \mathrm{D}$ \\
\hline & $06-01-77$ & 1 & $<100$ & 15 & - & $<2$ & 30 & 10 & $<10$ & $<0.5$ & $<1$ & - & $<20$ \\
\hline & $05-29-77$ & - & - & - & - & - & $<10$ & - & 8 & - & - & - & - \\
\hline & $05-27-77$ & - & - & - & - & - & 20 & - & 5 & - & - & - & - \\
\hline (C-42-6)20aaa-1 & $10-29-76$ & - & - & - & - & - & - & - & - & - & - & - & - \\
\hline (C-42-6)29dcb-S1 & $06-16-90$ & 1 & 85 & $<10$ & $<1$ & $<10$ & 4 & $<1$ & $<1$ & $<0.1$ & $<1$ & $<1$ & 5 \\
\hline \multirow[t]{3}{*}{$(\mathrm{C}-42-6) 30 \mathrm{baa}-1$} & $06-26-87 \cup$ & - & - & - & - & - & - & - & - & - & - & - & - \\
\hline & $07-25-86 U$ & - & - & - & - & - & - & - & - & - & - & - & - \\
\hline & $06-06-84 \mathrm{U}$ & $<0.5$ & 100 & $<1$ & $<5$ & 10 & 200 & 6 & 50 & $<0.1$ & $<0.5$ & $<2$ & 15 \\
\hline$(\mathrm{C}-42-6) 30 \mathrm{ccb}-\mathrm{S} 1$ & $10-01-76$ & - & - & - & - & - & - & - & - & - & - & - & - \\
\hline \multirow[t]{2}{*}{ (C-42-6) $30 \mathrm{cda}-2$} & $10-04-77$ & - & - & - & - & - & 30 & - & 4 & - & - & - & - \\
\hline & $09-28-76$ & - & - & - & - & - & - & - & - & - & - & - & - \\
\hline (C-42-6)30dbb-S1 & $06-02-77$ & - & - & - & - & - & 20 & - & 60 & - & - & - & - \\
\hline \multirow[t]{3}{*}{$(C-42-6) 30 \mathrm{dbc}-1$} & $06-26-87 \cup$ & - & - & - & - & - & - & - & - & - & - & - & - \\
\hline & $08-21-85 \mathrm{~S}$ & 1 & 150 & $<2$ & $<10$ & $<10$ & $<50$ & 10 & $<5$ & $<1$ & $<5$ & $<5$ & $<50$ \\
\hline & $06-02-77$ & - & - & - & - & - & 330 & - & 170 & - & - & - & - \\
\hline \multirow[t]{6}{*}{$(C-42-6) 31 d a c-1$} & $11-15-90 \mathrm{U}$ & $<5 D$ & $62 \mathrm{D}$ & $D<1 D$ & $<5 \mathrm{D}$ & $<20 \mathrm{D}$ & $<20 \mathrm{D}$ & $<5 D$ & $<5 \quad D$ & $<0.2$ & $\angle 1 D$ & $\angle 2 D$ & $28 \mathrm{D}$ \\
\hline & $07-29-86 \cup$ & - & - & - & - & - & - & - & - & - & - & - & - \\
\hline & $04-01-85 \mathrm{U}$ & $<0.5$ & $<50$ & $<1$ & $<5$ & $<20$ & $<30$ & $<5$ & $<10$ & $<0.1$ & $<0.5$ & $<2$ & 15 \\
\hline & $01-26-82 U$ & - & - & - & - & - & - & - & - & - & - & - & - \\
\hline & $04-29-81 \mathrm{U}$ & - & - & - & - & - & - & - & - & - & - & - & - \\
\hline & $09-28-76$ & - & - & - & - & - & - & - & - & - & - & - & - \\
\hline$(\mathrm{C}-42-6) 32 \mathrm{abd}-1$ & $10-29-76$ & - & - & - & - & - & - & - & - & - & - & - & - \\
\hline \multirow[t]{3}{*}{$(C-42-6) 32 b c c-1$} & $06-26-87 \cup$ & - & - & - & - & - & - & - & - & - & - & - & - \\
\hline & $08-14-85 U$ & - & - & - & - & - & - & - & - & - & - & - & - \\
\hline & $01-23-84 U$ & 3 & 60 & $<1$ & $<5$ & $<10$ & $<30$ & $<5$ & $<10$ & $<0.01$ & $<0.5$ & $<2$ & $<5$ \\
\hline$(\mathrm{C}-42-7) 25 \mathrm{ccc}-\mathrm{S} 1$ & $10-01-76$ & - & - & - & - & - & - & - & - & - & - & - & - \\
\hline (C-43-1)3bac-1 & $02-25-81$ & 1 & 50 & - & - & - & 1,500 & - & - & - & 0 & - & - \\
\hline (C-43-5) $2 \mathrm{bbd}-1$ & $07-15-77$ & - & - & - & - & - & 60 & - & $<10$ & - & - & - & - \\
\hline
\end{tabular}




\section{Table 3.-Selected trace element concentrations in water from wells and springs in the study area-Continued}

\begin{tabular}{|c|c|c|c|c|c|c|c|c|c|c|c|c|c|}
\hline $\begin{array}{c}\text { Well or spring } \\
\text { location }\end{array}$ & $\begin{array}{c}\text { Datc Ar } \\
\text { sampled } \\
\text { and } \\
\text { analytical } \\
\text { lab }\end{array}$ & $\begin{array}{l}\text { Arsenic, } \\
\text { dis- } \\
\text { solved } \\
\text { ( } \mu \mathrm{g} / \mathrm{L} \\
\text { as As) }\end{array}$ & $\begin{array}{c}\text { Barium, } \\
\text { dis- } \\
\text { solved } \\
\text { ( } \mu \mathrm{g} / \mathrm{L} \\
\text { as Ba) }\end{array}$ & $\begin{array}{c}\text { Cadmium, } \\
\text { dis- } \\
\text { solved } \\
(\mu \mathrm{g} / \mathrm{L} \\
\text { as Cd) }\end{array}$ & $\begin{array}{c}\text { Chro- } \\
\text { mium, } \\
\text { dis- } \\
\text { solved } \\
(\mu \mathrm{g} / \mathrm{L} \\
\text { as Cr) }\end{array}$ & $\begin{array}{l}\text { Copper, } \\
\text { dis- } \\
\text { solved } \\
(\mu \mathrm{g} / \mathrm{L} \\
\text { as } \mathrm{Cu})\end{array}$ & $\begin{array}{l}\text { Iron, } \\
\text { dis- } \\
\text { solved } \\
(\mu \mathrm{g} / \mathrm{L} \\
\text { as Fc) }\end{array}$ & $\begin{array}{l}\text { Lead, } \\
\text { dis- } \\
\text { solved } \\
(\mu \mathrm{g} / \mathrm{L} \\
\text { as } \mathrm{Pb})\end{array}$ & $\begin{array}{l}\text { Manga- } \\
\text { nesc, } \\
\text { dis- } \\
\text { solved } \\
(\mu \mathrm{g} / \mathrm{L} \\
\text { as } \mathrm{Mn})\end{array}$ & $\begin{array}{c}\text { Mercury, } \\
\text { dis- } \\
\text { solved } \\
(\mu \mathrm{g} / \mathrm{L} \\
\text { as } \mathrm{Hg})\end{array}$ & $\begin{array}{l}\text { Sele- } \\
\text { nium, } \\
\text { dis- } \\
\text { solved } \\
(\mu \mathrm{g} / \mathrm{L} \\
\text { as } \mathrm{Sc})\end{array}$ & $\begin{array}{c}\text { Silver, } \\
\text { dis- } \\
\text { solved } \\
(\mu \mathrm{g} / \mathrm{L} \\
\text { as } \mathrm{Ag})\end{array}$ & $\begin{array}{l}\text { Zinc, } \\
\text { dis- } \\
\text { solved } \\
(\mu \mathrm{g} / \mathrm{L} \\
\text { as } \mathrm{Zn})\end{array}$ \\
\hline (C-43-5)2ddd-S1 & $10-05-76$ & - & - & - & - & - & - & - & - & - & - & - & - \\
\hline$(C-43-5) 8 c c c-1$ & $09-15-86 \mathrm{~B}$ & $8-$ & - & - & - & - & $<100$ & - & 20 & - & - & - & - \\
\hline (C-43-7) $12 \mathrm{bdb}-1$ & $06-14-77$ & - & - & - & - & - & - & - & - & - & - & - & - \\
\hline (C-43-7) $16 \mathrm{dbb}-1$ & $06-14-90$ & 1 & 86 & $<10$ & $<1$ & $<10$ & 6 & $<1$ & $<1$ & $<0.1$ & $<1$ & $<1$ & 5 \\
\hline (C-43-8) 1 aca-S1 & $05-01-77$ & - & - & - & - & - & - & - & - & - & - & - & - \\
\hline (C-43-8)34bab-1 & $04-19-90 U$ & $U<5$ & 54 & $<1$ & $<5$ & $<20$ & 100 & $<5$ & 7 & $<0.2$ & $<1$ & $<2$ & $<20$ \\
\hline
\end{tabular}

Concentrations of dissolved solids in water from the Navajo aquifer ranged from 102 to $3,100 \mathrm{mg} / \mathrm{L}$, with only five samples exceeding $1,000 \mathrm{mg} / \mathrm{L}$. The median value was $230 \mathrm{mg} / \mathrm{L}$, indicating that most water from wells and springs in this aquifer is fresh (Heath, 1989, table 2). Dissolved-solids concentrations of $1,040 \mathrm{mg} / \mathrm{L}$ in water from well (C-43-1)3bac-1 and concentrations of $1,171 \mathrm{mg} / \mathrm{L}$ in water from well $(\mathrm{C}-41-7) 18 \mathrm{dbd}-1$ are the result of downward leakage of water with large concentrations of sulfate from the overlying Carmel Formation. A water sample collected on November 15, 1990, from the Kanab City Mace \#2 well, (C-42-6)19bdc-2, which yields water from the upper Navajo aquifer, had a dissolved-solids concentration of $144 \mathrm{mg} / \mathrm{L}$. Another sample collected on the same date from the Kanab City Chicken Canyon well, (C-42-6)31dac-1, in the Lamb Point aquifer, had a dissolved-solids concentration of $224 \mathrm{mg} / \mathrm{L}$. Larger concentrations of dissolved solids in water from the Lamb Point aquifer in this well could be the result of dissolution of minerals in the Tenney Canyon Tongue as ground water moves down through this shaly unit from the upper Navajo aquifer to the Lamb Point aquifer (Freethey, 1988, pl. 2).

Results of analyses of water samples from the Navajo aquifer indicate that ground water can be characterized as calcium magnesium bicarbonate water (Davis and DeWiest, 1966, p. 119). Water from some wells in the Navajo aquifer contains sulfate as a major constituent, in addition to large concentrations of sodium and magnesium, and this water is classified as calcium magnesium sulfate bicarbonate water. In a few wells, water contains an excess of sulfate compared with bicarbonate, and the water can be characterized as sodium bicarbonate sulfate water. Water hardness (expressed as the sum of calcium and magnesium in terms of an equivalent concentration of calcium carbonate) in the Navajo aquifer ranged from 84 to $1,200 \mathrm{mg} / \mathrm{L}$, with most concentrations less than $50(1 \mathrm{mg} / \mathrm{L}$ (table 2). According to the U.S. Geological Survey classification of hardness (Heath, 1989, table 2), most water from wells and springs in this aquifer is hard to very hard.

Arsenic concentrations in water from the Navajo aquifer did not exceed $4 \mu \mathrm{g} / \mathrm{L}$ (table 3 ). Barium concentrations as large as $500 \mu \mathrm{g} / \mathrm{L}$ were detected, although concentrations in most water samples were less than $100 \mu \mathrm{g} / \mathrm{L}$. Cadmium concentrations of as much as $15 \mu \mathrm{g} / \mathrm{L}$ were present in a water sample collected from well (C-42-6)19bdc-2 on June 1, 1977, exceeding the State of Utah standard for this metal by $5 \mu \mathrm{g} / \mathrm{L}$. Analyses of water samples collected on November 15, 1990 , however, indicated cadmium concentrations less than $1 \mu \mathrm{g} / \mathrm{L}$. The largest chromium concentration was $14 \mu \mathrm{g} / \mathrm{L}$, although most concentrations were less than $5 \mu \mathrm{g} / \mathrm{L}$. Copper concentrations of as 
much as $20 \mu \mathrm{g} / \mathrm{L}$ were considerably less than the $1,000 \mu \mathrm{g} / \mathrm{L}$ limit for this metal. The maximum lead concentration was $41 \mu \mathrm{g} / \mathrm{L}$, with most concentrations below $10 \mu \mathrm{g} / \mathrm{L}$. Maximum concentrations of mercury did not exceed $1 \mu \mathrm{g} / \mathrm{L}$. Selenium concentrations were less than $5 \mu \mathrm{g} / \mathrm{L}$. A maximum concentration of $10 \mu \mathrm{g} / \mathrm{L}$ was obtained for silver, with concentrations in most water samples less than $2 \mu \mathrm{g} / \mathrm{L}$. The largest zinc concentration was $1,000 \mu \mathrm{g} / \mathrm{L}$, less than the $5,000 \mu \mathrm{g} / \mathrm{L}$ standard for this metal. Concentrations of zinc greater than $100 \mu \mathrm{g} / \mathrm{L}$ are typically associated with zinc-plated (galvanized) water-storage tanks. In addition to these trace elements, fluoride and nitrate (including nitrite) were also analyzed. Maximum fluoride concentrations in water samples from the Navajo aquifer did not exceed $1 \mathrm{mg} / \mathrm{L}$. The maximum concentration of nitrate (including nitrite) was $10 \mathrm{mg} / \mathrm{L}$.

Results of analyses of the eight water samples collected in 1990 from wells and springs in the Navajo aquifer indicated that concentrations of organic chemicals (pesticides and volatile organic compounds) did not exceed the State ground-water-quality standards for these constituents (table 1). Because analytical results were reported only to detection limits, trace quantities of these chemicals may be present; however, detection limits for most of these chemicals are substantially less than the levels established to meet the State of Utah standards for ground-water protection.

Gross-alpha-particle activity in water samples from the Navajo aquifer ranged from less than 1 to $8 \mathrm{pCi} / \mathrm{L}$ (table 2). Although the State of Utah ground-water-quality standard for grossalpha-particle activity is $15 \mathrm{pCi} / \mathrm{L}$, including radium-226, water samples having an activity greater than $5 \mathrm{pCi} / \mathrm{L}$ are also analyzed separately for radium-226. In all samples with a gross-alpha-particle activity exceeding $5 \mathrm{pCi} / \mathrm{L}$, further testing for radium-226 indicated activities less than the 3 $\mathrm{pCi} / \mathrm{L}$ limit for this isotope. In well (C-41-7)18dbd-1, results of analyses obtained from four water samples collected from 1981 to 1989 by the Utah Department of Health indicated gross-alpha-particle activity ranging from less than 2 to $8 \mathrm{pCi} / \mathrm{L}$. Although a reduction in activity was evident from 1981 to 1985 , an activity of $7 \mathrm{pCi} / \mathrm{L}$ was noted in 1989.

\section{Straight Cliffs Aquifer}

The median dissolved-solids concentration in water from the Straight Cliffs aquifer was $330 \mathrm{mg} / \mathrm{L}$. Dissolved-solids concentrations in water from 1 well and 19 springs in the Straight Cliffs Formation ranged from 177 to $1,250 \mathrm{mg} / \mathrm{L}$ (table 2). The dissolved-solids concentration exceeded the limit for freshwater $(1,000 \mathrm{mg} / \mathrm{L})$ in only one sample. Dissolved-solids concentrations in water from 13 springs and 1 well in the Wahweap Formation ranged from 139 to $1,140 \mathrm{mg} / \mathrm{L}$, with the concentration in only 1 sample exceeding the freshwater limit. Dissolved-solids concentrations in water from four springs discharging from the Kaiparowits Formation were 166, 205, 238 , and $487 \mathrm{mg} / \mathrm{L}$.

Spring-water analyses from the Straight Cliffs aquifer generally indicate calcium magnesium bicarbonate water, with water analyses from a few springs also indicating calcium magnesium sulfate bicarbonate water in some areas. Hardness of water in samples from the Straight Cliffs aquifer ranged from 150 to $1,100 \mathrm{mg} / \mathrm{L}$, with most concentrations less than $500 \mathrm{mg} / \mathrm{L}$ (table 2). Consequently, most water from springs in this aquifer is hard to very hard.

The maximum concentration of arsenic in water samples from the Straight Cliffs aquifer was $8 \mu \mathrm{g} / \mathrm{L}$ (table 3). A concentration of $910 \mu \mathrm{g} / \mathrm{L}$ barium was detected in one sample, just under 

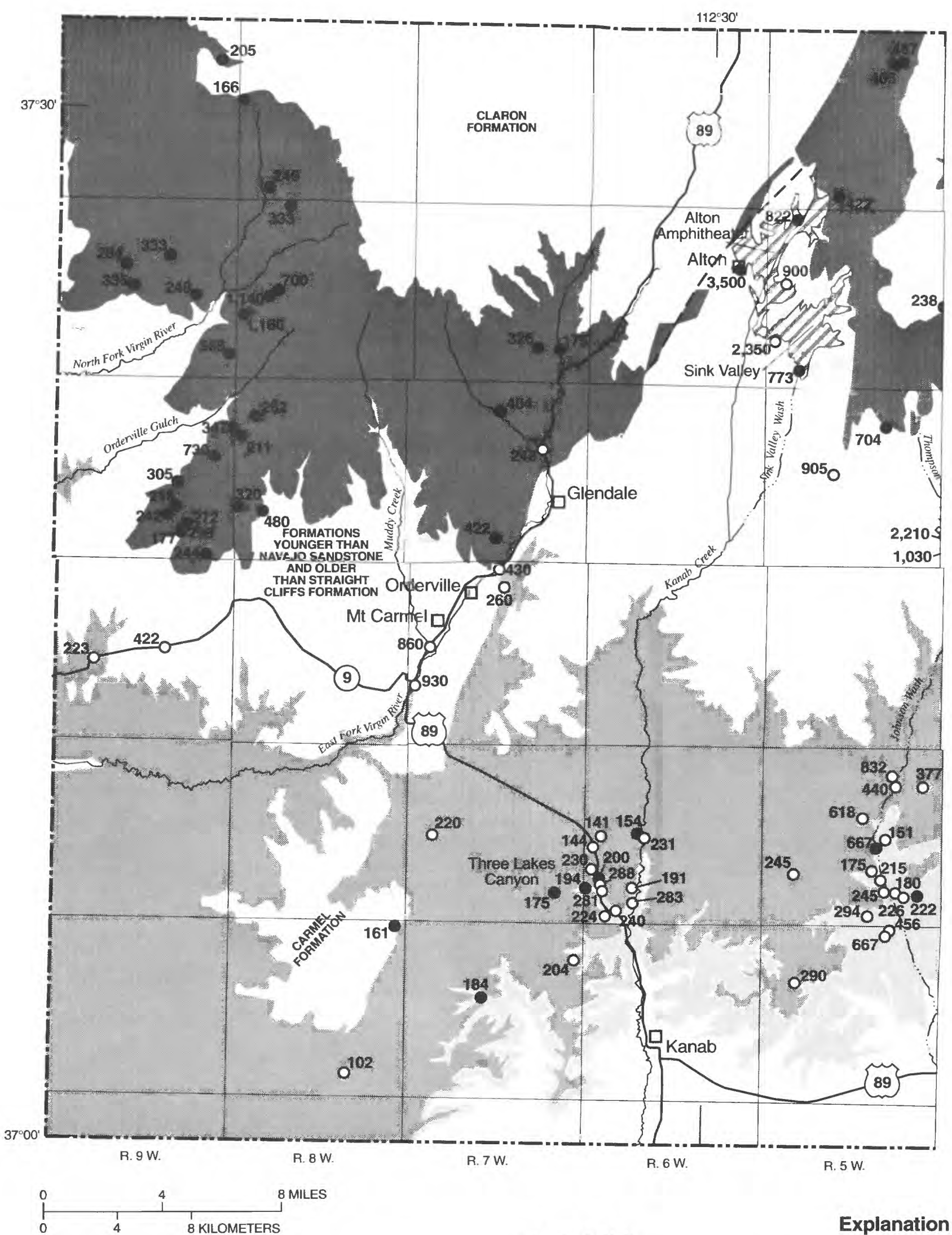

Geologic Units

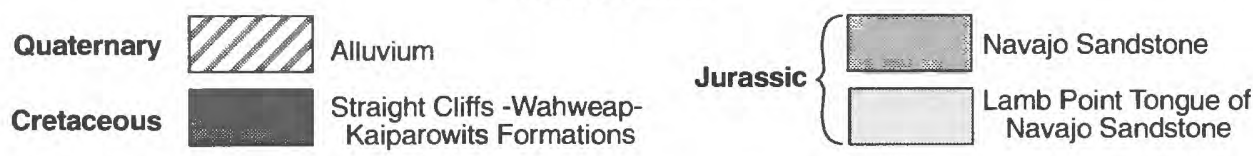

Figure 7. Location of wells and springs, and 


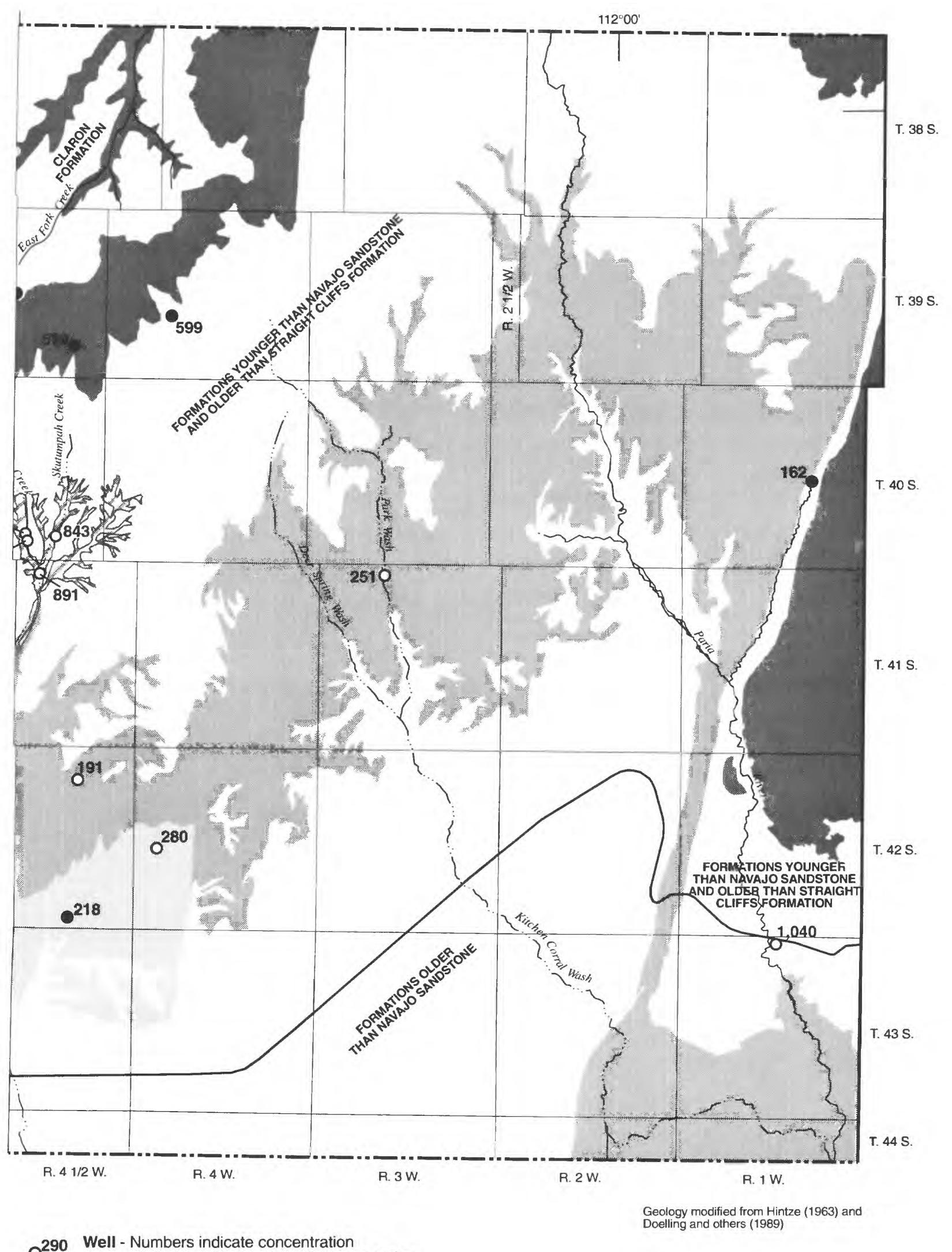

$\mathrm{O}^{290}$ Well - Numbers indicate concentration
of dissolved solids, in milligrams

218 Spring - Numbers indicate concentration of dissolved solids, in milligrams per liter

\section{Approximate boundary between Claron Formation and \\ formations older than Straight Cliffs Formation}

concentration of dissolved solids in ground water. 
the $1,000 \mu \mathrm{g} / \mathrm{L}$ limit for this element, but all other results of analyses were less than $200 \mu \mathrm{g} / \mathrm{L}$. Cadmium concentrations were less than $3 \mu \mathrm{g} / \mathrm{L}$. Chromium concentrations were less than $10 \mu \mathrm{g} / \mathrm{L}$. The maximum concentration of copper in water was $24 \mu \mathrm{g} / \mathrm{L}$. The largest concentration of lead in water from this aquifer was $35 \mu \mathrm{g} / \mathrm{L}$. Mercury concentrations did not exceed $1 \mu \mathrm{g} / \mathrm{L}$. Concentrations of selenium were less than $5 \mu \mathrm{g} / \mathrm{L}$. The maximum concentration of silver in water was 6 $\mu \mathrm{g} / \mathrm{L}$. The largest concentration of zinc in water did not exceed $50 \mu \mathrm{g} / \mathrm{L}$. In addition to these trace elements, fluoride and nitrate (including nitrite) concentrations did not exceed $1 \mathrm{mg} / \mathrm{L}$. Maximum values of gross-alpha-particle activity in water samples from the Straight Cliffs aquifer were 3 $\mathrm{pCi} / \mathrm{L}$, less than the $5 \mathrm{pCi} / \mathrm{L}$ limit necessary for radium-226 analyses.

\section{Alluvial Aquifers}

Dissolved-solids concentrations in water samples collected from five wells and four springs in alluvial aquifers ranged from 283 to $3,500 \mathrm{mg} / \mathrm{L}$ (table 2), with a median of $838 \mathrm{mg} / \mathrm{L}$. Four values, $1,030,2,210,3,080$, and 3,500, exceeded the limit of $1,000 \mathrm{mg} / \mathrm{L}$ for freshwater. Water from these wells also had some of the largest concentrations of sodium, chloride, and sulfate. Because ground water in these shallow aquifers is usually fresh, large dissolved-solids concentrations are probably caused by seepage to the alluvium from adjacent or underlying rocks that contain mineralized water. Ground water samples from members of the Carmel Formation typically contain large concentrations of dissolved sulfate from partial dissolution of gypsum. Most wells and springs in alluvial aquifers are in Alton Amphitheater and Sink Valley, which are underlain by the Tropic Shale, and in Thompson Creek and Skutumpah Creek, which are underlain by the Carmel Formation.

Results of analyses of water samples collected from alluvial aquifers indicate a range in water type. Most water from these aquifers is calcium magnesium sulfate bicarbonate, but other types include calcium magnesium bicarbonate, magnesium calcium sulfate bicarbonate, and calcium magnesium sodium bicarbonate sulfate. This range in composition indicates an influx and mixture of water from other formations. Hardness of water from alluvial aquifers ranged from about 500 to as much as $2,500 \mathrm{mg} / \mathrm{L}$ (table 2), indicating very hard ground water.

The maximum fluoride concentration was $0.6 \mathrm{mg} / \mathrm{L}$ (table 2 ), and the maximum concentration of nitrate (including nitrite) was $1.9 \mathrm{mg} / \mathrm{L}$. Water samples from alluvial aquifers have not been analyzed for trace metals, organic chemicals, or radionuclides.

\section{Classification of Ground Water in the Principal Aquifers}

One of the primary goals of this investigation was to provide information necessary to classify the ground water and therefore principal aquifers, according to quality of water. In the State of Utah Ground-Water-Quality Protection Regulations (Utah Department of Health, 1989), six ground-water classes have been established to define the overall quality of water in aquifers ("Supplemental Information" section at back of report). These classes are based on concentrations of dissolved solids, selected trace metals, organic chemicals (pesticides and volatile organic compounds), and radionuclide activity that have been adopted as standards for ground-water protection. 
According to the State of Utah Ground-Water-Quality Protection Regulations, ground water that is drinking-water quality must have concentrations of dissolved solids less than 3,000 $\mathrm{mg} / \mathrm{L}$, in addition to having none of the prescribed trace metals, organic chemicals (pesticides and volatile organic compounds), radionuclides, or other constituents in concentrations that exceed established standards. Ground water that is not drinking-water quality may still be used for industrial or commercial purposes. A summary of the 95 wells and springs used in this study including their respective aquifers and dissolved-solids concentrations from the most recent water analyses are shown in table 4. Each site has also been evaluated and generally categorized according to the standards outlined in the Ground-Water-Quality Protection Regulations (Utah Department of Health, 1989).

In the study area, most water samples from wells and springs in the Navajo aquifer have dissolved-solids concentrations less than $500 \mathrm{mg} / \mathrm{L}$ and contaminant (trace metal, organic, radionuclide) concentrations that do not exceed the ground-water-quality standards listed in table 1 . As a result, the ground water is classified as Pristine, Irreplaceable, or Ecologically Important (class I). Wells and springs in the Navajo aquifer with dissolved-solids concentrations between $500 \mathrm{mg} / \mathrm{L}$ and $3,000 \mathrm{mg} / \mathrm{L}$ also do not have contaminant concentrations that exceed the ground-water quality standards. Ground water in these areas is classified as Drinking-Water Quality (class II).

Water-sample analyses for springs and wells in the Straight Cliffs aquifer indicate that ground water can be classified as Pristine, Irreplaceable, or Ecologically Important (class I), where dissolved-solids concentrations are less than $500 \mathrm{mg} / \mathrm{L}$, and Drinking-Water Quality (class II), where dissolved-solids concentrations exceed $500 \mathrm{mg} / \mathrm{L}$, but are less than $3,000 \mathrm{mg} / \mathrm{L}$. Analyses of water samples from these sites also indicates that concentrations of trace metals, organic chemicals, and radionuclides do not exceed the State ground-water-quality standards.

Analyses of water samples from alluvial aquifers indicate dissolved-solids concentrations generally range from 500 to $1,000 \mathrm{mg} / \mathrm{L}$ and trace metal concentrations do not exceed the State ground-water-quality standards. As a result, ground water in these areas is classified as DrinkingWater Quality (class II). Water from several wells in alluvial aquifers was also classified as Pristine, Irreplaceable, or Ecologically Important (class I), based on dissolved-solids concentrations less than $500 \mathrm{mg} / \mathrm{L}$.

A water sample collected from spring (C-39-6)13bbb-S1 had a dissolved-solids concentration of $3,500 \mathrm{mg} / \mathrm{L}$. Because this concentration exceeded $3,000 \mathrm{mg} / \mathrm{L}$, water from this spring was classified as Limited-Use Ground Water (class III), even though concentrations of trace metals, organic chemicals, and radionuclides in the water sample did not exceed the established State ground-water-quality standards.

\section{SUMMARY}

Three principal aquifers have been identified in western Kane County, Utah. These are the Navajo aquifer, the Straight Cliffs aquifer, and alluvial aquifers. The Navajo aquifer is separated into the upper Navajo and Lamb Point aquifers by the Tenney Canyon Tongue of the Kayenta Formation between the Sevier Fault and the Paunsaugunt Fault. The Straight Cliffs aquifer consists of the Straight Cliffs, Wahweap, and Kaiparowits Formations. These formations are considered to be a single aquifer in the study area because of the absence of distinct confining units between the 


\section{Table 4.-Dissolved-solids concentration in water from wells and springs, and general classification according to the State of Utah Ground-Water-Quality Protection Regulations}

Well/spring location: Refer to section on data-site numbering system.

Dissolved-solids concentration: $\mathrm{mg} / \mathrm{L}$, milligrams per liter; $\mathrm{D}$, dissolved solids at 180 degrees Celsius; all others sum of constituents.

General classification: I, Pristine, Irreplaceable, or Ecologically Important Ground Water; II, Drinking-WaterQuality Ground Water; III, Limited-Use Ground Water.

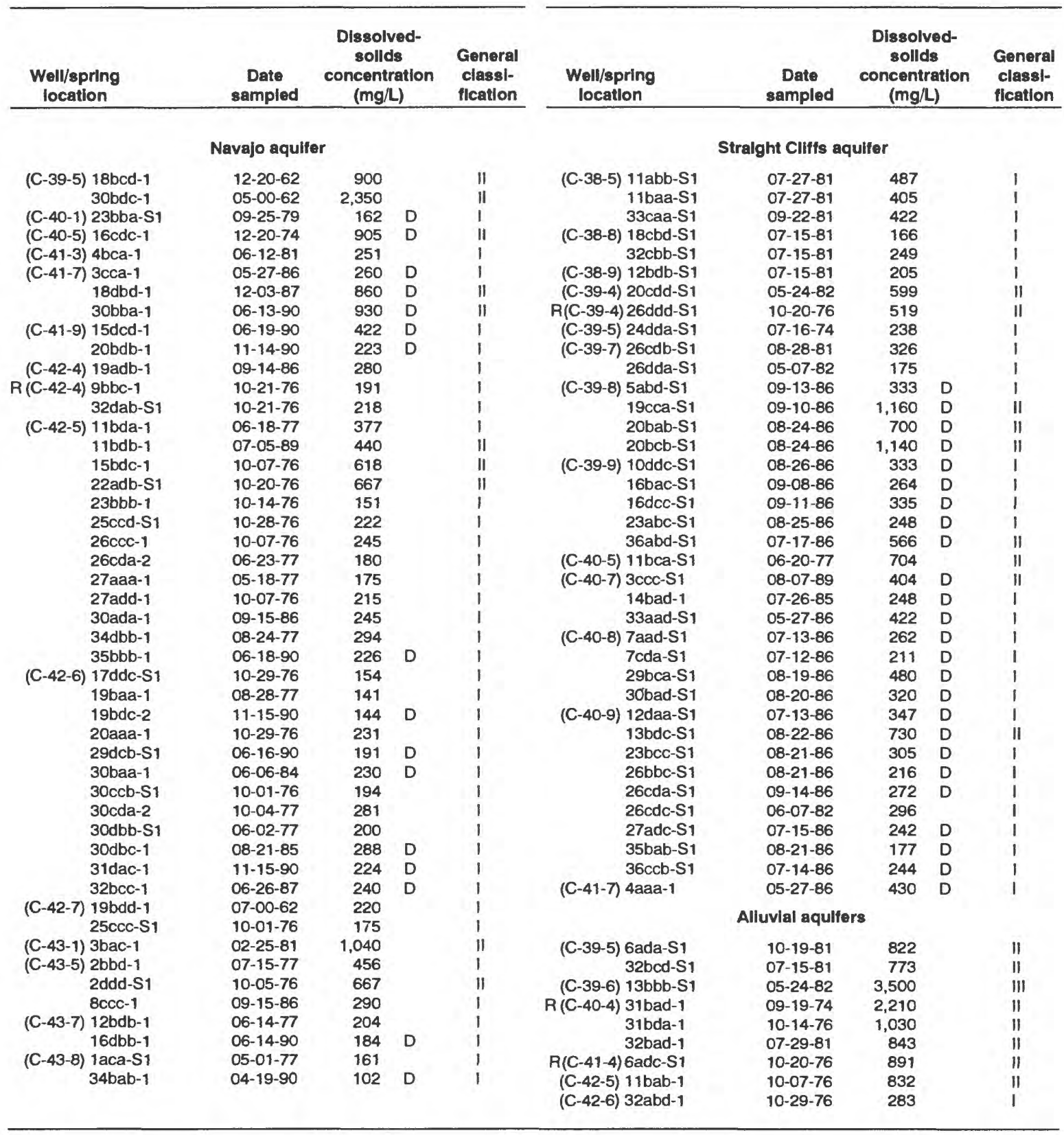


formations. Where the Navajo Sandstone and Straight Cliffs, Wahweap, and Kaiparowits Formations crop out, the aquifers within the formations are unconfined. Where the formations are buried beneath overlying (younger) rocks to the north, the aquifers are confined. Alluvial aquifers are locally present within ephemeral stream valleys and are unconfined.

Saturated thickness of the Navajo aquifer varies from 50 to 100 feet near the southern margin of the Navajo Sandstone outcrop, to as much as 2,000 feet where the top of the Navajo Sandstone is more than 2,000 feet beneath the land surface. Direction of ground-water movement in the Navajo aquifer is toward discharge areas along incised drainages. Saturated thickness of the Straight Cliffs aquifer is poorly known because of the lack of well data, but probably ranges from less than 100 feet near the erosional edge of the outcrops of the formations to about 2,000 feet, where the aquifer is confined by overlying units to the north and presumed to be fully saturated. Thickness of alluvial aquifers is generally less than 100 feet.

Most recharge to the principal aquifers takes place over outcrop areas by infiltration directly into bedrock, through unconsolidated deposits covering bedrock, by seepage along faults and joints, and by stream losses. Where formations containing the aquifers do not crop out, recharge may take place by infiltration through overlying rocks. Factors influencing the quantity of recharge to the principal aquifers include quantity of winter precipitation; type and density of vegetative cover; evapotranspiration; thickness of soil cover; type, extent, and hydraulic conductivity of unconsolidated deposits; topographic slope; and the continuity, aperture, and spacing of vertical fractures. Infiltration of precipitation through unconsolidated deposits forms an important pathway of potential recharge to the Navajo aquifer. The greatest potential for contamination to the principal aquifers is along major highways. Utilizing maximum values of hydraulic conductivity, effective porosity, and hydraulic gradient, travel-time for a contaminant 2 miles upgradient from a Kanab City municipal well in Three Lakes Canyon was computed to be as small as 76 years, but could be considerably shorter if flow is along fractures.

Chemical analyses of samples from 44 wells and 51 springs were used to assess the overall ground-water quality in the principal aquifers. Dissolved-solids concentrations in water from the Navajo aquifer ranged from 102 to $3,100 \mathrm{mg} / \mathrm{L}$, with a median of $230 \mathrm{mg} / \mathrm{L}$. Dissolved-solids concentrations in water from the Straight Cliffs aquifer ranged from 139 to $1,250 \mathrm{mg} / \mathrm{L}$, with a median of $330 \mathrm{mg} / \mathrm{L}$. Dissolved-solids concentrations in water from alluvial aquifers ranged from 283 to $3,500 \mathrm{mg} / \mathrm{L}$, with a median of $838 \mathrm{mg} / \mathrm{L}$. Most water samples from the principal aquifers have dissolved-solids concentrations less than $1,000 \mathrm{mg} / \mathrm{L}$. Concentrations of selected trace metals, organic chemicals, and radionuclides do not exceed the established standards as outlined in the State of Utah Ground-Water-Quality Protection Regulations. Consequently, most water in the principal aquifers can be classified as Pristine, Irreplaceable, Ecologically Important, or Drinking-Water Quality. 


\section{REFERENCES CITED}

Bingham Engineering, 1979, Alton coal project, 1978 groundwater investigation: prepared for Utah International, Inc., Salt Lake City, Utah, 46 p., 3 plates, 2 appendices.

-1981, Alton coal project, 1980-1981 groundwater investigation, part 1, test drilling and pumping data at Bald Knoll: prepared for Utah International, Inc., Salt Lake City, Utah, $30 \mathrm{p}$.

-1987, Alton coal project, Navajo aquifer investigation: prepared for Utah International, Inc., Salt Lake City, Utah, 93 p., 8 appendices.

Blanchard, P. J., 1986, Ground-water conditions in the Kaiparowits Plateau area, Utah and Arizona, with emphasis on the Navajo Sandstone: Utah Department of Natural Resources Technical Publication 81, $87 \mathrm{p}$.

Cordova, R. M., 1981, Ground-water conditions in the upper Virgin River and Kanab Creek basins area, Utah, with emphasis on the Navajo Sandstone: Utah Department of Natural Resources Technical Publication 70, $87 \mathrm{p}$.

Davis, S. N., and DeWiest, R. J. M., 1966, Hydrogeology: New York, John Wiley \& Sons, Inc., $463 \mathrm{p}$.

Doelling, H. H., Davis, F. D., and Brandt, C. J., 1989, The geology of Kane County, Utah - geology, mineral resources, geologic hazards: Utah Geological and Mineral Survey Bulletin $124,192 \mathrm{p}$.

Freethey, G. W., 1988, Geohydrology of the Navajo Sandstone in western Kane, southwestern Garfield, and southeastern Iron Counties, Utah: U. S. Geological Survey Water-Resources Investigations Report 88-4040, 43 p.

Goode, H. D., 1964, Reconnaissance of water resources of a part of western Kane County, Utah: Utah Geological and Mineralogical Survey Water-Resources Bulletin 5, 63 p.

-1966, Second reconnaissance of water resources in western Kane County, Utah: Utah Geological and Mineralogical Survey Water-Resources Bulletin 8, $44 \mathrm{p}$.

Heath, R. C., 1989, Basic ground-water hydrology: U. S. Geological Survey Water-Supply Paper $2220,84 \mathrm{p}$.

Heilweil, V. M., and Freethey, G. W., 1992, Simulation of ground-water flow and water-level declines caused by proposed withdrawals, Navajo Sandstone, southwestern Utah and northwestern Arizona: U. S. Geological Survey Water-Resources Investigations Report 90-4105, $51 \mathrm{p}$.

Hintze, L. F., 1963, Geologic map of southwestern Utah, in Guidebook to the geology of southwestern Utah, Heylmun, E. B., ed.: Intermountain Association of Petroleum Geologists, twelfth annual field conference, Salt Lake City, Utah, $226 \mathrm{p}$.

Jeppson, R. W., Ashcroft, G. L., Huber, A. L., Skogerboe, G. V., and Bagley, J. M., 1968, Hydrologic atlas of Utah: Utah Water Research Laboratory, Utah Agriculture Experiment Station, Utah State University, 306 p.

Utah Department of Hcalth, Division of Environmental Health, Bureau of Water Pollution Control, August 1989, State of Utah ground water quality protection regulations: State of Utah Department of Health, $30 \mathrm{p}$. 
Stokes, W. L., 1988, Geology of Utah: University of Utah and Utah Geological and Mineral Survey, Occasional Paper No. 6, 280 p.

U.S. Geological Survey, Office of Water Data Coordination, 1989, Subsurface-water flow and solute transport - Federal glossary of selected terms: $38 \mathrm{p}$.

U.S. Weather Bureau, 1963, Normal October - April precipitation (1931-1960) for the State of Utah: Map of Utah, scale 1:500,000.

Uygur, Kadir, 1980, Hydraulic and petrographic characteristics of the Navajo Sandstone in southern Utah: University of Utah, Department of Geology and Geophysics, unpublished Master's thesis, $134 \mathrm{p}$. 


\section{SUPPLEMENTAL INFORMATION}

Six ground-water classes have been outlined in the State of Utah Ground-Water-Quality Protection Regulations (Utah Department of Health, 1989) and are as follows:

Class IA - Pristine Ground Water - highest quality ground water with TDS ${ }^{1}$ less than $500 \mathrm{mg} / \mathrm{L}$ and no contaminant (trace metal, organic chemical, or radionuclide) concentrations that exceed the State ground-water-quality standards.

Class IB - Irreplaceable Ground Water - good-quality ground water that is a source of water for a public drinking-water system for which no reliable supply of comparable quality and quantity is available because of economic or institutional constraints; TDS may not exceed $2,000 \mathrm{mg} / \mathrm{L}$.

Class IC - Ecologically Important Ground Water - ground water is a source of ground-water discharge that is important to the continued existence of a wildlife habitat; designation depends on establishing the source of discharge, utilization, and importance for wildlife habitat.

Class II - Drinking-Water-Quality Ground Water - high quality ground water with TDS greater than 500 but less than $3,000 \mathrm{mg} / \mathrm{L}$ and no contaminant concentrations that exceed the State ground-water-quality standards.

Class III - Limited-Use Ground Water - ground water that has TDS between 3,000 and 10,000 $\mathrm{mg} / \mathrm{L}$ or has one or more contaminants that exceed the ground-water-quality standards.

Class IV - Saline Ground Water - ground water with TDS greater than $10,000 \mathrm{mg} / \mathrm{L}$.

${ }^{1}$ TDS, Total Dissolved Solids; equivalent U.S. Geological Survey terminology in this report is dissolvedsolids concentrations. 